Portland State University

PDXScholar

\title{
Tribal Revegetation Project Final Project Report: 92-Acre Area, Area 5 Radioactive Waste Management Complex, Nevada National Security Site, Nevada
}

Jeremy Spoon

Portland State University, jspoon@pdx.edu

Brittany Kruger

Desert Research Institute

Richard Arnold

Desert Research Institute

Kate Monti Barcalow

Portland State University, barcalow@pdx.edu

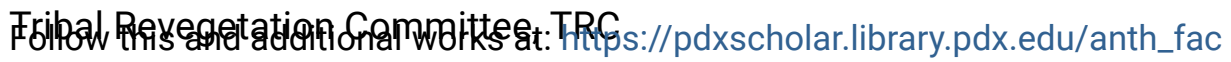

Part of the Anthropology Commons, Environmental Sciences Commons, and the Environmental Studies Commons

Let us know how access to this document benefits you.

\section{Citation Details}

Spoon, Jeremy, Kruger, Brittany, Arnold, Richard, Barcalow, Kate, \& Tribal Revegetation Committee, TRC. Tribal Revegetation Project Final Project Report: 92-Acre Area, Area 5 Radioactive Waste Management Complex, Nevada National Security Site, Nevada. United States. https://doi.org/10.2172/1773633

This Technical Report is brought to you for free and open access. It has been accepted for inclusion in Anthropology Faculty Publications and Presentations by an authorized administrator of PDXScholar. Please contact us if we can make this document more accessible: pdxscholar@pdx.edu. 


\section{Tribal Revegetation Project}

Final Project Report

\section{2-ACre Area, Area 5 Radioactive Waste Management Complex NeVAda National SECURITy Site, Nevada}

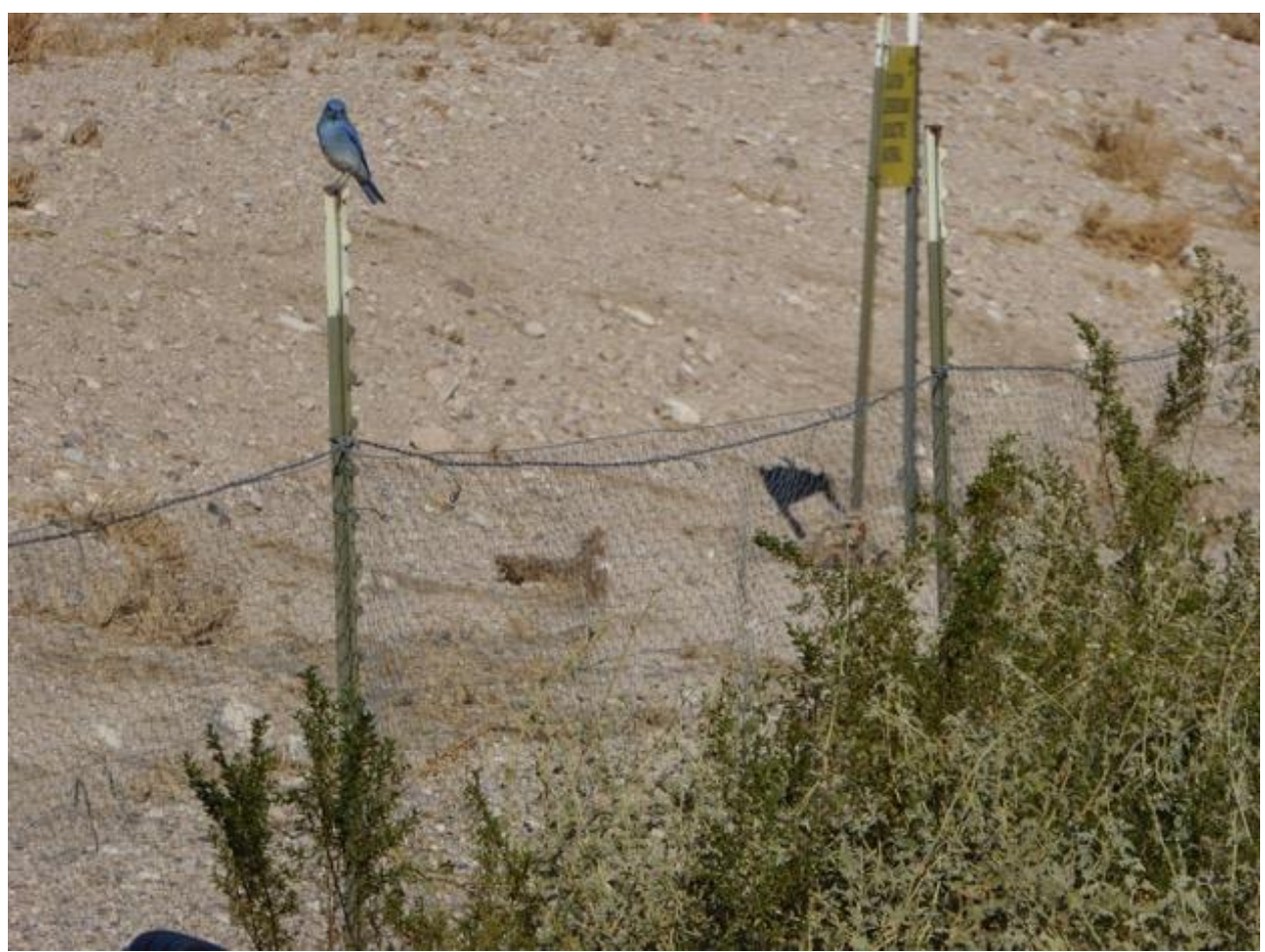

Prepared and Submitted by

Jeremy Spoon, Brittany Kruger, Richard Arnold, Kate Barcalow, and the Tribal Revegetation Committee

Desert Research Institute

Portland State University in collaboration with

the 16 American Indian Tribal nations and affiliated groups with cultural and historical ties to the NNSS

March 2021

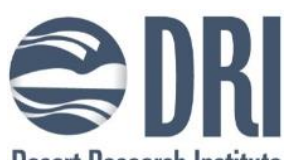


Reference herein to any specific commercial product, process, or service by trade name, trademark, manufacturer, or otherwise does not necessarily constitute or imply its endorsement, recommendation, or favoring by the United States Government or any agency thereof or its contractors or subcontractors.

Cover photo: Mountain bluebird with outplants at Area 5 Radioactive Waste Management Complex during fall planting in early December 2017. The presence of the mountain bluebird is considered a culturally significant event observed by the Tribal Revegetation Committee at the commencement of the project. 


\title{
Tribal Revegetation Project
}

Final Project Report

\section{2-Acre Area, Area 5 Radioactive Waste Management Complex NeVAda National Security Site, Nevada}

\author{
Prepared and Submitted by \\ Jeremy Spoon, Brittany Kruger, Richard Arnold, Kate Barcalow, and \\ the Tribal Revegetation Committee \\ Desert Research Institute \\ Portland State University \\ in collaboration with \\ the 16 American Indian Tribal nations and affiliated groups with \\ cultural and historical ties to the NNSS
}

\author{
Prepared for \\ U.S. Department of Energy \\ Environmental Management Nevada Program \\ Las Vegas, Nevada
}

March 2021

The work upon which this report is based was supported by the U.S. Department of Energy under Contracts \#DE-NA0000939 and \#DE-NA0003590. Approved for public release; further dissemination unlimited. 
THIS PAGE INTENTIONALLY LEFT BLANK 


\section{EXECUTIVE SUMMARY}

Nuwu (Southern Paiute), Newe (Western Shoshone), and Nиити (Owens Valley Paiute) are linguistically related, Numic-speaking peoples who are part of the broader Uto-Aztecan language group. Numic peoples view the land as a holistic, living, sentient being with feelings and purpose. The land is personified with human characteristics and it needs to be experienced to be understood through "learning by doing." Numic peoples do not support ground disturbing activities within their ancestral lands, including activities tied to the storage of low-level radioactive waste or classified materials on the NNSS, which they view as culturally inappropriate. These deep-rooted ancestral connections are the impetus for reinforcing Numic responsibility for healing disturbed areas by integrating respect and patience with consistent Tribal interaction. Tribal Ecological Knowledge (TEK) is the science of describing Tribal approaches for understanding natural resources. Numic TEK is embedded in traditional teachings learned incrementally over time though experience and it evolves through lessons learned and responses to environmental changes over millennia. Therefore, TEK can broaden and enhance Western scientific knowledge associated with revegetation, especially in highly disturbed areas.

The project blended TEK with Western scientific ecological methods to create a vegetative cover within test plots on the 92-Acre Area located at the Radioactive Waste Management Complex (RWMC) located in Area 5 on the Nevada National Security Site (NNSS). The vegetated test plots were systematically created for the Department of Energy (DOE) in tandem with the existing Federal Facilities Agreement and Consent Order (FFACO) with the Nevada Department of Environmental Protection (NDEP). Three previous contractor-lead attempts at revegetation, one targeting full cover revegetation and two targeting test plot revegetation, did not achieve the anticipated results at this location. When presented to the 16 American Indian Tribal nations and affiliated groups with cultural and historical ties to the NNSS, the group appointed a Tribal Revegetation Committee (TRC) that included six expert Tribal knowledge holders to collaborate with an ethnoecologist/cultural anthropologist and two biologists.

Project design, planning, seed and outplant selection, spiritual land preparation, and methodology were guided by the TRC and an ethnoecologist/cultural anthropologist from Portland State University (PSU) and biologists from Desert Research Institute (DRI). Using TEK, the TRC recommended a specific seed mixture that contained nine native plant species and three species of outplants. The revegetation effort included preparing and planting thirty $10 \mathrm{~m} \times 10 \mathrm{~m}(32.8 \mathrm{ft} \times 32.8 \mathrm{ft})$ seeded plots, twelve of which also included outplants; and eight $10 \mathrm{~m} \times 100 \mathrm{~m}(32.8 \mathrm{ft} \times 328 \mathrm{ft})$ plots that only received outplants, all atop a waste cell cover. The TRC and the project team creatively adapted TEK with Western scientific methods so that the planned revegetation efforts could occur within the safety and security parameters of the RWMC. Test plots were subjected to one of five soil treatments with varying combinations of straw or mulch applications, soil amendment, and/or outplant planting and one of two watering treatments (watered or unwatered). Planting was divided into two events: one in the fall season and another during the subsequent spring season based on TEK and a corresponding recommendation from the TRC. Monitoring and spiritual management was conducted by the TRC to evaluate plant progress on a monthly basis (in conjunction with the biologist and anthropologist) during each respective growing season for 
a period of three years after planting. This approach allowed Tribal members the opportunity to conduct traditional blessings and other culturally appropriate activities to restore balance to the land in accordance with Tribal protocols.

Following TEK-guided methods, successful plant establishment from seed stock and outplants was observed in many plots. Overall, plots planted in the spring, as recommended by the TRC, showed higher rates of outplant survival and native seedling emergence than those planted in the fall. This finding is significant because it is contrary to the original guidance and previous approaches provided for planting in this region. The TRC believes the frequent co-occurrence of native seedlings near surviving outplants indicates an important symbiotic relationship understood by Tribal communities and overlooked by others. Watered outplants displayed much higher survivability than unwatered plants, even after watering was reduced after the plants were established. Soil amendments and mulch created higher densities of native plants from seed. Many native seedlings showed significant delays in germination, which is considered a normal adaptation to desert climates. Some native plants did not germinate until the third growing year, whereas others germinated during the first growing year, which demonstrates the complexity of the desert environment. Evidence of native insects, reptiles, mammals, and birds, as well as native plants that were not part of the planted species, were noted and considered culturally significant. Despite the presence of non-native plants, native outplants continued to thrive and the incidence of native plant germination from seed increased over time. These successful revegetation results where previous efforts were unsuccessful reinforce the importance of integrating regionally appropriate, TEK-guided methodology with Western science to achieve positive results and the necessity of integrating Tribal involvement in all stages of the revegetation effort. Expanded approaches coupled with Tribal knowledge and tools from Western science addressed a complex problem tied to revegetating atop a low-level radioactive waste cell. The level of Tribal participation serves as a progressive model for building collaborative relationships and addressing ecological challenges on the NNSS. 


\section{ACKNOWLEDGMENTS}

This unique blended effort represents the open minds, hard work, and dedication of multiple partners and individuals. It builds on Tribal recommendations relating to revegetation efforts on disturbed lands at the NNSS, which span more than 30 years. A debt of gratitude is owed to the DOE Environmental Management Nevada Program (EM NV) and the NDEP for their ongoing support and guidance. Tiffany Gamero (Long-term Monitoring Activity Lead, U.S. Department of Energy Environmental Management Nevada Program) and Christine Andres (Bureau of Federal Facilities Chief, Nevada Division of Environmental Protection) remained actively involved and were instrumental in the actualization and success of this project. Involvement from the 16 American Indian Tribal nations and affiliated groups with cultural and historical ties to the NNSS was central to integrating the knowledge and values that became the basis for blending unique cultural approaches that had not been considered previously. The project is humbled to have extensive contributions from the Indigenous peoples of the land who agreed to offer solutions to a complex problem. Thanks also to Navarro, Mission Support and Test Services, and Soil-Tech, Inc., for their project support, especially our friends at the RWMC and John Fowler and Juan Alvarado with Navarro. 
THIS PAGE INTENTIONALLY LEFT BLANK 


\section{CONTENTS}

EXECUTIVE SUMMARY .iii

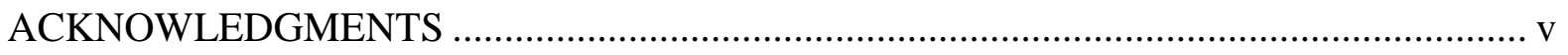

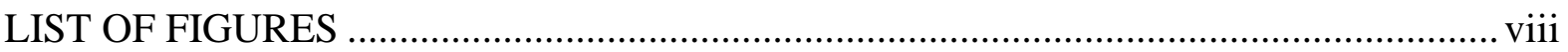

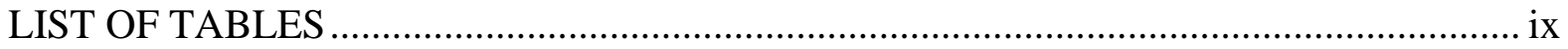

LIST OF ACRONYMS …………………………

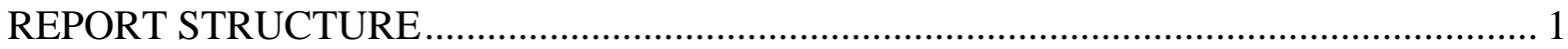

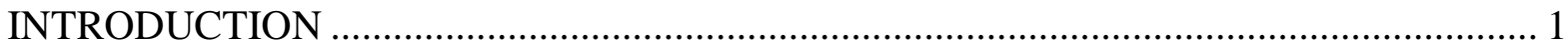

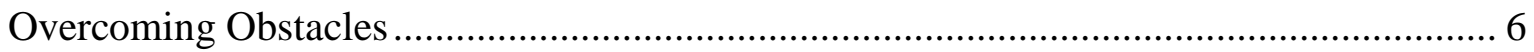

The Land is Alive, Has Feelings, and Needs to be Personified and Experienced .............. 10

Healing the Land with Respect and Patience................................................................. 12

Spiritual Management and Following Cultural Protocols ................................................. 16

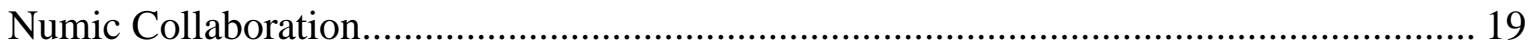

COMPLETED PROJECT TASKS PER FISCAL YEAR ………………............................ 20

ANNUAL FIELD EVALUATION MEETING AND BLESSINGS ..................................... 20

MODIFICATIONS TO FY20 ACTIVITIES BECAUSE OF COVID-19 PANDEMIC ........ 21

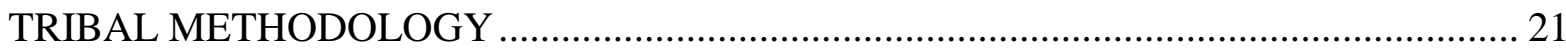

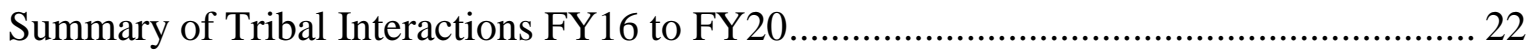

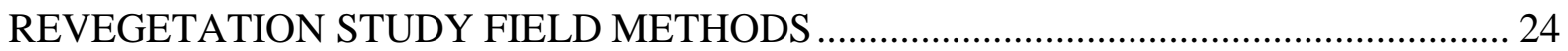

Summary of Plot Design and Planting...................................................................... 24

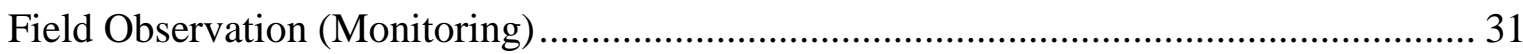

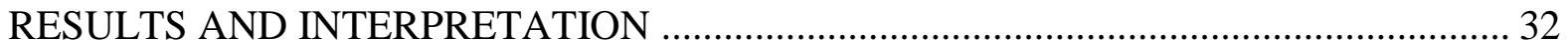

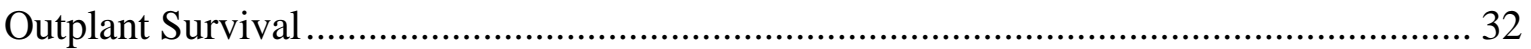

Native Plants from Seed ………………………………........................................ 39

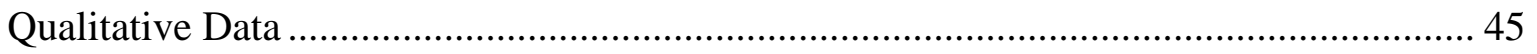

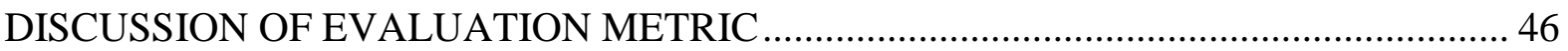

Tribal Definitions of Revegetation Success................................................................... 46

Blended TEK and Western Science Evaluation Metric .................................................... 47

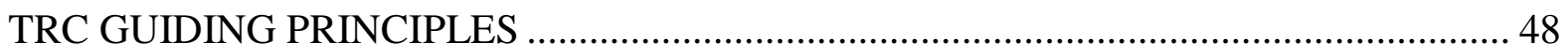

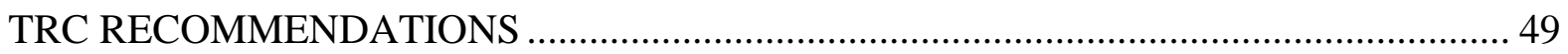

PROPOSED NEXT STEPS FOR REVEGETATION AT THE 92-ACRE AREA AND

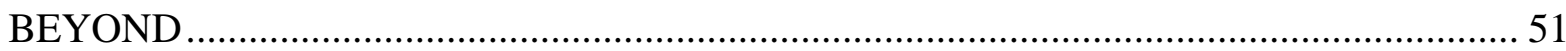

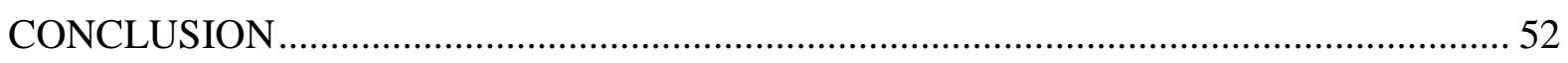

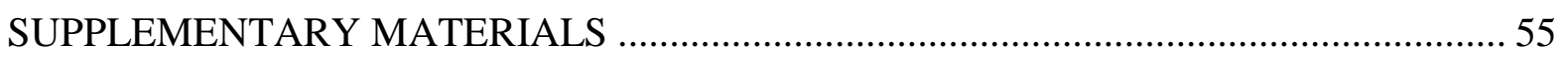

Quantitative Data Used for Figure Construction ........................................................... 55 
TRC Descriptions of Revegetation Success …………………................................... 59

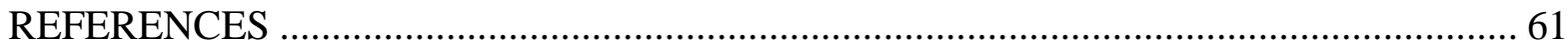

APPENDIX A: Photographs from select FY18, FY19, and FY20 activities ....................... A-1

\section{LIST OF FIGURES}

1. Tribal Revegetation Committee, DOE, Management and Operating (M\&O) contractor, PSU, and DRI participants at the March 2016 Project Review Meeting....... 7

2. Richard Arnold (Nuwu-Southern Paiute) speaking to the Tribal Revegetation Committee during the March 2016 Project Review Meeting........................................... 7

3. Numic spiritual adviser with $\mathrm{M} \& \mathrm{O}$ contractor staff on a site visit at the February 2017 Spiritual Land Preparation and Field Plan Development Meeting.......... 8

4. Tribal Revegetation Committee, PSU, and DRI participants during February 2017 Spiritual Land Preparation and Field Plan Development Meeting. 8

5. Tribal Revegetation Committee, PSU, and DRI participants in the February 2017 Spiritual Land Preparation and Fieldwork Plan Development Meeting. ......................... 8

6. Tribal Revegetation Committee members reinforce their responsibility to heal the land at Radioactive Waste Management Complex (RWMC) Area 5 "no matter what condition the land is in."

7. Tribal Revegetation Committee members interact with the land and identify non-native plants in the 92-Acre Area at the Radioactive Waste Management Complex in Area 5 in June 2016.

8. A TRC member evaluates and interacts with the 92-Acre Area in 2016 at the onset of the revegetation.

9. Total TRC interactions with the Tribal Revegetation Project site at the 92-Acre Area per (a) federal fiscal year and (b) annual TRC interactions averaged across the entire project (FY16 to FY20) and across the intensive planting and monitoring

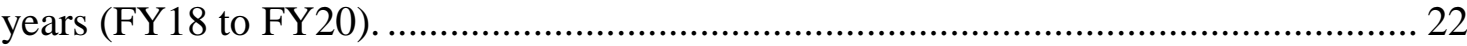

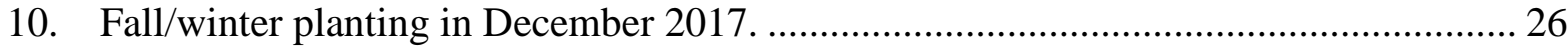

11. Plot design and location of plots planted in the fall/winter. ......................................... 26

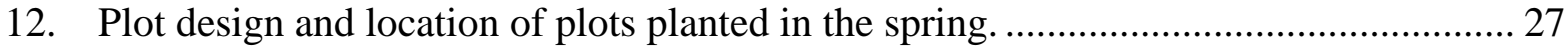

13. Members of the TRC and a representative from PSU counting plants within the randomly placed $1 \mathrm{~m} \times 1 \mathrm{~m}(3.3 \mathrm{ft} \times 3.3 \mathrm{ft})$ quadrat within a $10 \mathrm{~m} \times 10 \mathrm{~m}$ $(32.8 \mathrm{ft} \times 32.8 \mathrm{ft})$ plot.

14. Average percent survival (a-c) and average height (in $\mathrm{cm}$ ) of surviving plants (d-f) across the growing season for outplants within $10 \mathrm{~m} \times 10 \mathrm{~m}(32.8 \mathrm{ft} \times 32.8 \mathrm{ft})$ plots for all three fiscal years of monitoring.

15. Average percent survival and standard deviation (error bars) across the growing season for outplants within $10 \mathrm{~m} \times 100 \mathrm{~m}(32.8 \mathrm{ft} \times 328 \mathrm{ft})$ plots, for all three fiscal years of monitoring. 
16. Average height of surviving outplants and standard deviation (error bars) across the growing season for outplants within $10 \mathrm{~m} \times 100 \mathrm{~m}(32.8 \mathrm{ft} \times 328 \mathrm{ft})$ plots, for all three fiscal years of monitoring.

17. Average native plant densities (plants per square meter $\left[\mathrm{m}^{2}\right]$ ) in $10 \mathrm{~m} \times 10 \mathrm{~m}$ $(32.8 \mathrm{ft} \times 32.8 \mathrm{ft})$ plots for all years of monitoring.

18. Average invasive plant densities (plants per square meter $\left[\mathrm{m}^{2}\right]$ ) in $10 \mathrm{~m} \times 10 \mathrm{~m}$ $(32.8 \mathrm{ft} \times 32.8 \mathrm{ft})$ plots for all years of monitoring.

19. (a) Average animal signs observed per visit and (b) average insect observations per visit to the Tribal Revegetation Project site.

20. Average number of native species observed qualitatively in $10 \mathrm{~m} \times 10 \mathrm{~m}$ $(32.8 \mathrm{ft} \times 32.8 \mathrm{ft}$ ) plots per fiscal year (observed within $10 \mathrm{~m} \times 10 \mathrm{~m}[32.8 \mathrm{ft} \times 32.8 \mathrm{ft}]$ plots but outside the $1 \mathrm{~m} \times 1 \mathrm{~m}(3.3 \mathrm{ft} \times 3.3 \mathrm{ft})$ sampling square $).$

\section{LIST OF TABLES}

1. Tribal Revegetation Project activities FY16 to FY21.......................................... 23

2. Treatments used on $10 \mathrm{~m} \times 10 \mathrm{~m}(32.8 \mathrm{ft} \times 32.8 \mathrm{ft})$ plots. ............................. 25

3. List of species used in the seed mix and amount of seed.................................... 28

4. List of plants used for outplants in both the seeded plots and the transplant plots..... 29

5. Variable selection and corresponding Numic ecological knowledge and adaptation for Tribal Revegetation Project (seeded and outplant treatments)........................... 30

6. Variable selection and corresponding Numic ecological knowledge and adaptation for Tribal Revegetation Project (outplant-only treatments).

7. Heat-map table showing most commonly observed native plants by plot treatment (average plant density as plant $\left./ \mathrm{m}^{2}\right)$ in $10 \mathrm{~m} \times 10 \mathrm{~m}(32.8 \mathrm{ft} \times 32.8 \mathrm{ft})$ plots corresponding to planting events during all fiscal years. 


\section{LIST OF ACRONYMS}

\begin{tabular}{|c|c|}
\hline AICP & American Indian Consultation Program \\
\hline${ }^{\circ} \mathrm{C}$ & degrees Celsius \\
\hline CGTO & Consolidated Group of Tribes and Organizations \\
\hline $\mathrm{cm}$ & centimeters \\
\hline DOE & Department of Energy \\
\hline DRI & Desert Research Institute \\
\hline${ }^{\circ} \mathrm{F}$ & degrees Fahrenheit \\
\hline $\mathrm{ft}$ & feet \\
\hline $\mathrm{ft}^{2}$ & square feet \\
\hline FFACO & Federal Facility and Consent Order \\
\hline FY & fiscal year \\
\hline EM NV & Environmental Management Nevada Program \\
\hline GIS & geographic information system \\
\hline in & inches \\
\hline $\mathrm{L}$ & liters \\
\hline $\mathrm{lb}$ & pounds \\
\hline $\mathrm{m}$ & meters \\
\hline $\mathrm{m}^{2}$ & square meters \\
\hline $\mathrm{M} \& \mathrm{O}$ & Management and Operating \\
\hline MSTS & Mission Support and Test Services \\
\hline NDEP & Nevada Division of Environmental Protection \\
\hline NNSA/NFO & National Nuclear Security Administration, Nevada Field Office \\
\hline NNSS & Nevada National Security Site \\
\hline NSSAB & Nevada Site Specific Advisory Board \\
\hline PPE & personal protective equipment \\
\hline PSU & Portland State University \\
\hline RWMC & Radioactive Waste Management Complex \\
\hline TEK & Tribal Ecological Knowledge \\
\hline TRC & Tribal Revegetation Committee \\
\hline
\end{tabular}




\section{REPORT STRUCTURE}

This report represents the culmination of a progressive collaboration that integrated Tribal Ecological Knowledge (TEK) to guide a revegetation effort at the Radioactive Waste Management Complex (RWMC) atop an unnatural and highly disturbed landscape. The TEK framework was supported by Western science to address the challenging environmental problem overseen by the U.S. Department of Energy (DOE) Environmental Management Nevada Program (EM NV) and the Nevada Division of Environmental Protection (NDEP). Because the project structure was guided by Tribal knowledge throughout all stages of the effort, it is important that Tribal perspectives first be understood to add context about the complexities of the land in tandem with the uniqueness of this study. To better understand the cultural dynamics associated with the 92-Acre Area, an extensive ethnographic background is provided for context and supplemented with Tribal statements to interpret the results, guiding principles, and recommendations.

\section{INTRODUCTION}

Nuwu (Southern Paiute), Newe (Western Shoshone), and Nuити (Owens Valley Paiute) are Indigenous peoples of the Great Basin and Northern Mojave Desert. The Creator placed them on the land "at the beginning of time when the world was new." They view their ancestral land as a holistic, sentient being with feelings and purpose. The land is personified with human characteristics and it needs to be experienced to be understood through "learning by doing." These three ethnic groups are linguistically related, Numic-speaking peoples who are part of the broader Uto-Aztecan language group (Kelly and Fowler, 1986; Thomas et al., 1986; Stoffle et al., 1990). Although these three groups are distinct, they share many similarities, including cultural and historical ties to the Nevada National Security Site (NNSS) managed by the DOE National Nuclear Security Administration, Nevada Field Office (NNSA/NFO) (Stoffle et al., 2001). Traditional knowledge integrates thousands of years of incrementally learned environmental information and understanding that are passed on orally from generation to generation. These complex epistemological views relating to the land are embedded in traditional customs and beliefs.

Numic peoples do not support ground disturbing activities, including the storage of low-level radioactive waste and classified materials at the NNSS, which they consider culturally inappropriate. However, because of their familial ties to the land as a relative since the beginning of time, it becomes Numic peoples responsibility to heal disturbed areas with respect and patience no matter what condition the land is in through consistent Tribal interactions. Numic peoples first evaluate the land to determine if the land is sick and out of balance; when the land is sick, Numic peoples are adversely affected and suffer from the same afflictions.

Healing land affected by ground disturbing activities which Numic peoples do not support creates strife and requires difficult decisions for Numic peoples. Importantly, complex problems such as revegetating atop low-level radioactive waste and other material require innovative approaches and solutions. In the case of the Tribal Revegetation Project, Numic peoples worked in collaboration with the DOE, NDEP, DRI, PSU, and support contractors to heal the land by blending Tribal Ecological Knowledge (TEK) with Western science in new and progressive 
ways. This blended knowledge included adapting Numic TEK with rules, regulations, and expectations associated with low-level radioactive waste and materials. Numic peoples considered this project a significant, although not insurmountable, challenge.

Beginning in 1991, NNSA initiated the American Indian Consultation Program (AICP) to interact with the 16 American Indian Tribal nations and affiliated groups with cultural and historical ties to the NNSS. In 1994, the Tribes aligned to form the Consolidated Group of Tribes and Organizations (CGTO), now referred to as the 16 American Indian Tribal nations and affiliated groups with cultural and historical ties to the NNSS. This group serves as a mechanism to work together and speak through one collective voice to share unique Tribal perspectives. Throughout their involvement, this group has been responsible for developing a wide range of recommendations focusing on cultural resource management, including vegetation restoration on the NNSS (American Indian Writers Subgroup, 1996; Stoffle et al., 2001).

The Tribal Revegetation Project is attributed to DOE interactions with the Nevada Site Specific Advisory Board (NSSAB) about a recurring problem at the 92-Acre Area in Area 5 of the RWMC in Area 5 on the NNSS. The NSSAB is comprised of community representatives from surrounding counties and designated liaisons who meet regularly to receive briefings on EM NV activities and provide formal recommendations for EM NV consideration.

The NSSAB was informed about the revegetation challenges at the 92-Acre Area, including a requirement for a vegetative cover in accordance with the Federal Facility Agreement and Consent Order (FFACO), a regulatory agreement between the State of Nevada, EM NV, and the Department of Defense. The FFACO requires federal land managers to address sites affected by historical contamination to be addressed with suitable mediation strategies in compliance with the agreement.

The NSSAB deliberated on possible mitigation strategies for successfully developing an evapotranspirative cover at the 92-Acre Area. During the meeting, the spokesperson who serves as an NSSAB liaison was asked for Tribal input on the challenging situation. The spokesperson stated "...the land was sick and out of balance. Who better knows the land than the Tribal people who have been here since the beginning of time?" The spokesperson provided additional background on Tribal revegetative options and suggested integrating Tribal involvement in the effort to examine methods for developing a suitable vegetative cover. The NSSAB agreed and recommended EM NV support a Tribal Revegetation Project at the 92-Acre Area, which was ultimately approved. Support and guidance from Tiffany Gamero (Long-term Monitoring Activity Lead) at the DOE EM NV and Christine Andres (Bureau of Federal Facilities Chief) at the NDEP in particular made this effort possible and ultimately successful.

Upon approval, the 16 American Indian Tribal nations and affiliated groups with cultural and historical ties to the NNSS reviewed the project and appointed a genderbalanced Tribal Revegetation Committee (TRC) that included six Tribal subject matter experts from the three ethnic groups. According to a TRC member, "I'm thankful we searched out a balance in the Tribes and male/female. That's a good thing." The committee was responsible for providing guidance to the project using Numic TEK in tandem with Western scientific methods and assistance from an ecologist at Desert Research Institute 
(DRI) and a cultural anthropologist/ethnoecologist at Portland State University (PSU). The cultural anthropologist/ethnoecologist served as a critical conduit to blend TEK and Western science in all facets of the study.

The TRC participants included Kenny Anderson, Betty Cornelius, and Johnny Hill, Jr. (Nuwu); Barbara Durham, Maurice Frank-Churchill, and Warren Graham (Newe); and Danelle Gutierrez and Ross Stone (Nuumu). The TRC also included three spiritual leaders/expert knowledge holders, including Lawanda Laffoon $(\mathrm{N} u w u)$, Gonzalo Mendez (Newe), and Qwina West (Nuитu).

The Numic TEK applied to this project encompasses a complex, cumulative system of adaptive knowledge and practices involving personified relationships with the environment, which is comprised of sentient beings. This knowledge is embedded in traditional teachings learned incrementally over time though experience, or "learning by doing," that evolves through lessons learned and responses to environmental changes (Berkes and Turner, 2006; Turner and Berkes, 2006; Berkes, 2012; Spoon, 2014). Research illustrates TEK can enhance Western scientific knowledge associated with conservation, adaptive practices, and natural resource management (e.g., Huntington [2000], Moller et al. [2004], Raymond et al. [2010], Woodward et al. [2012], Spoon et al. [2020], and Hill et al. [2020]). For example, the Numic sequence of Tribal cultural relationships and interactions with the land create opportunities for small-scale disturbances that enhance biodiversity, such as coppicing, pruning, transplanting, whipping plants to stimulate growth, and patch burning (Kelly and Fowler, 1986; Fowler, 1996; Spoon et al., 2015; Fowler and Garey-Sage, 2016). Furthermore, Numic TEK integrates unique observations and experiences tied to environmental phenomena within their ancestral homelands that have been experienced over millennia, such as climate, and species composition and diversity (Stoffle et al., 2001; Spoon and Arnold, 2012; Spoon et al., 2015). Although the land may look strong or similar to adjacent areas, the TRC noted, "...the land is fragile and can take years to reclaim itself." This context-specific information is a vital component for understanding and implementing effective revegetation in highly disturbed areas.

Prior to fiscal year 2018 (FY18), EM NV contractors made three unsuccessful revegetation efforts on the 92-Acre Area, including one on an entire cover and two within selected test plots (Ostler, 2015). Because prior revegetation efforts in nearby locations responded positively, contractors expected similar results on the 92-Acre Area, but that did not occur. The initial attempts focused only on seeding the cover, altering mulch levels, and using sporadic inefficient irrigation, as was done in other nearby locations. According to the $\mathrm{TRC}$, irrigation was not tapered off properly to allow the plant communities to acclimate to the soil and natural precipitation once the plants were established. The contractors did not use outplants or transplants and relied solely on seeded species. Herbicide was used to prevent the growth of non-native plants, which the TRC members believe created challenges. The contractor's approaches did not include caging developing plants to prevent herbivory. The plants were rarely visited or monitored to document growth. The TRC members stated that the relationships required to properly nurture the plant communities were therefore not made. Additionally, previous efforts did not identify the no-growth areas that differed from areas with greater revegetation density. The subsequent Tribal Revegetation Project described in this report sought to address these points while considering suitable mitigation strategies. 
The TRC members shared that the DOE and contractors viewed the revegetation at the 92-Acre Area like a "project that has a beginning and an end" or "a job that they need to move on from." A TRC member explained that "They [DOE/contractors] see it as a project and something that they are bound by the state to bring back the land where it used to be... our view is more that we see something that is sick, and that we want to heal it and we need to heal it in order for us to be healthy." From a Tribal perspective, once relationships are made with the land and the healing process unfolds, there cannot be an end. Healing and sustaining cultural ecological balance is an ongoing process. Numic peoples will therefore always need to heal their ancestral lands no matter their condition. A TRC member explained that "they [contractors] just wanted to satisfy a goal with the agency instead of taking a consideration that plants are alive and they do serve a purpose." This statement illustrates the primary differences in how the TRC views revegetation compared with the previous contractors. The Tribes know the land differently than non-Indians, and therefore perceive of the revegetation process in distinct ways. A TRC member explained it in the following way: "I think that's where we differ from DOE...we believe in praying to the land, we believe in praying to the land for the plants to grow and to do good." According to TRC members, the DOE and contractors do not view the land as connected to themselves and do not make relationships with it. By not making relationships, it makes it easier to abuse the land and not perceive the consequences. Viewing the land as an inanimate object or separated from humans contrasts with the Numic perspectives where humans and the land are interconnected as relatives "since the beginning of time when the world was new." The TRC members believe the land needs to be viewed holistically rather than separate, such as considering a single cover at the 92-Acre Area rather than its overall relationship with the surrounding area. Because if the land feels isolated, it will ultimately affect revegetation planning, approaches, and practices.

Recognizing the challenges described above, the TRC deliberated on the 92-Acre Area site conditions, FFACO expectations, and background information that was provided by the DOE and contractors. The TRC and spiritual advisors agreed to participate in the revegetation study focusing on test plots that integrated TEK and elements of Western science to address revegetation challenges at the 92-Acre Area. The revegetation model subsequently developed for implementation in FY18 refined typical Western revegetation efforts by incorporating extensive Tribal involvement and guidance at all stages of the effort. This approach included special prayers and culturally appropriate activities throughout the process that were facilitated by spiritual leaders to prepare the land before the demarcation of test plots and revegetation activities were initiated. Additionally, TEK helped select specific plant species and outplants that have beneficial relationships that can adapt to the unnatural, disturbed landscape. The TRC integrated TEK into selecting the appropriate planting seasons, planting techniques, irrigation schedules, soil amendments, mulch additions, and spiritual management with ongoing Tribal interactions, which were considered critical to properly nurturing the developing plant communities.

The soils at the 92-Acre Area consisted of soil removed from the RWMC borrow pits and trenches, where nutrients are not optimal. The soil amendment suggested by the TRC included integrating organic-rich surface soils from the NNSS to supplement the current topsoil. These Tribal recommendations guided the study and were based on TEK, which significantly deviated from the methods used during the previous three unsuccessful attempts by contractors to revegetate the area. 
Blending TEK with Western scientific became the impetus to systematically revegetating select test plots on the cover of a low-level radioactive waste disposal cell to determine the appropriate paths forward for expanding the vegetative cover. This approach achieved successful vegetation within test plots and became a progressive model for ecological restoration. A TRC member explained it this way:

...this is the first time I've ever been a part of something like this, so it is actually really unique...I don't think anything's ever happened like this where you're sharing cultural knowledge with the scientific side of things and combining the two together.

To accomplish this unique and blended approach, TEK was central to every stage of the effort to ensure that Tribal voices and perspectives were key drivers in the process. An important part the effort included four collaborative ethnographic interviews at the onset of the project in 2016 (FY16). These interviews were carried out by TRC members who spoke with spiritual leaders from their respective Tribes (Spoon and Barcalow, 2017; Spoon and Barcalow, 2016). Additionally, the TRC conducted a systematic literature review to identify key aspects of Numic TEK relevant to the research design and implemented this knowledge during the design of the project methods and corresponding fieldwork plan. Collectively, PSU, DRI, and the TRC planned and implemented systematic recordation methods to promote consistency in data collection during field observations and build on the prayers that were placed on the land at the onset of the revegetation effort, which were a key component of the spiritual and cultural land management. The TRC guided the preparation and planting of thirty $10 \mathrm{~m} \times 10 \mathrm{~m}(32.8 \mathrm{ft} \times 32.8 \mathrm{ft})$ seeded plots and eight $10 \mathrm{~m} \times 100 \mathrm{~m}$ $(32.8 \mathrm{ft} \times 328 \mathrm{ft})$ transplant plots for a combined total of 38 plots planted (planting occurred in FY18). Plant monitoring data were collected during 18 field observations by the TRC with support from DRI and PSU, which commenced in FY18 and continued throughout FY19 and FY20, although FY20 activities were significantly modified because of restrictions associated with the COVID-19 pandemic (see below). At the end of each year, the TRC, DRI, and PSU gathered for an annual meeting to assess the land, evaluate plant growth, and conduct spiritual management, which was identified as a critical element to the success of the project. Additionally, the TRC made three presentations at the annual Tribal Update Meeting between NNSA/NFO and the 16 American Indian Tribal nations and affiliated groups with cultural and historical ties to the NNSS to share preliminary results, cultural insights, and important feedback with the larger Tribal community. To promote consistency with previous revegetation efforts, conducting three years of observations were suggested in the Fieldwork Plan (Spoon and Barcalow, 2017) and successfully implemented in this project. Accordingly, three years of monitoring is an acceptable standard for similar ecological studies of this magnitude (Kotanen, 1997; Abella et al., 2012), although the TRC considers this project a limited window to view the development for such a slow-growing ecosystem. Lastly, seven in-depth, collaborative, ethnographic interviews (the methodology described in Spoon [2014] and Spoon and Arnold, [2012]) were carried out at the end of the three-year period to better understand Tribal perspectives on revegetation success. The interviews were conducted by the project cultural anthropologist/ethnoecologist, but the TRC helped shape the semistructured interview questions for this portion of the project and provided feedback on the interpretation of the results. An informed consent statement was read and shared with each TRC member at the onset of all interviews to ensure transparency in how the ethnographic information would be disseminated and in what venues. All ethnographic interviews and 
annual interactions were transcribed and inductively coded in corresponding themes. The transcripts were verified for frequency and salience of those themes (Spoon et al., 2020; Spoon, 2014; Spoon and Arnold, 2012).

The TRC, Numic spiritual experts, PSU, and DRI developed four general and five specific goals at the onset of this project that were listed in the Fieldwork Plan (Spoon and Barcalow, 2017, p. 3). The project successfully accomplished all stated goals within the scale of the 38 test plots where feasible and within the project period. The general goals accomplished included: 1) collaboration between culturally affiliated Tribal groups with compatible facilitators, including, the DOE, PSU, DRI, and support contractors; 2) increased animal and insect presence in test plots and/or in or near the 92-Acre Area; and 3) the creation of a replicable methodology relevant to other locations on the NNSS. The specific goals accomplished included: 1) Numic peoples were brought to the 92-Acre Area to perform spiritual preparation of the land prior to the revegetation study; 2) Numic peoples were integrated throughout the entire revegetation study process and provided spiritual management which coincided with Tribal interactions; 3) test plots were revegetated with a diversity of healthy native plants that will thrive into the future; and 4) new Tribal representatives were introduced into the project, which was important for providing continuity and building TRC capacity. The final general goal of this project is to co-manage the natural and cultural resources of the entire 92-Acre Area. The specific final goal is to support revegetation activities on the NNSS by sustaining a greenhouse with a compatible seed bank, as described in the "TRC Recommendations" section of this report.

\section{Overcoming Obstacles}

This project was unique both in structure (blending of TEK and Western ecological methods [Figures 1 to 5]) and objective (using blended methods to revegetate test plots for a low-level radioactive waste disposal site), which created many obstacles not typically considered in cultural activities. Moreover, Tribal members discussed the necessity of brokering ideas and sharing information cautiously because providing too much information to the government or others could be misinterpreted, and therefore harm their people and adversely affect the land. Furthermore, Numic peoples view the land as a holistic being with feelings and a purpose. Separating the 92-Acre Area from the surrounding landscape is unnatural because it is interconnected, similar to the human body. These challenges pushed the project team to create innovative approaches that ultimately shaped the approach. 


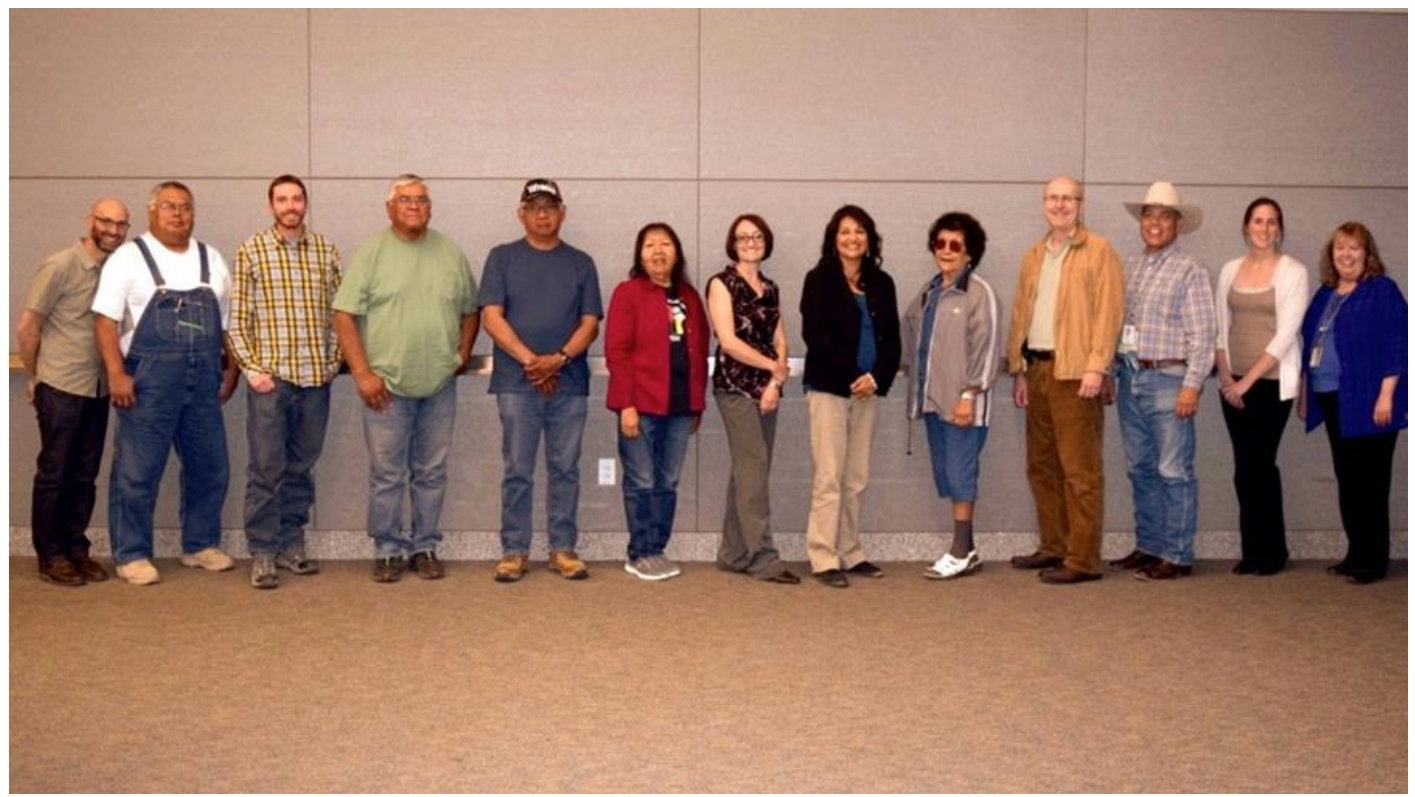

Figure 1. Tribal Revegetation Committee, DOE, Management and Operating (M\&O) contractor, PSU, and DRI participants at the March 2016 Project Review Meeting.

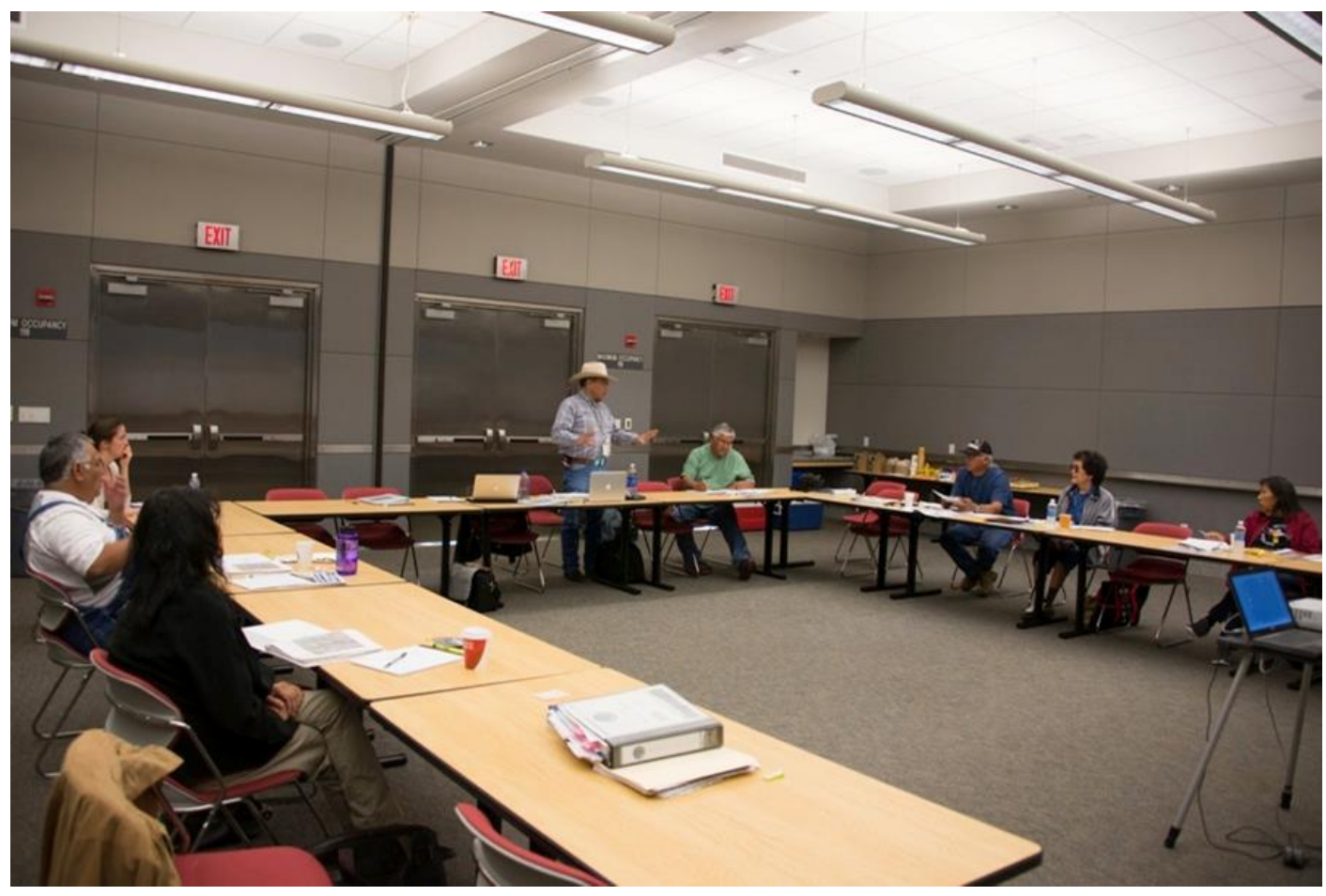

Figure 2. Richard Arnold (Nuwu-Southern Paiute) speaking to the Tribal Revegetation Committee during the March 2016 Project Review Meeting. 


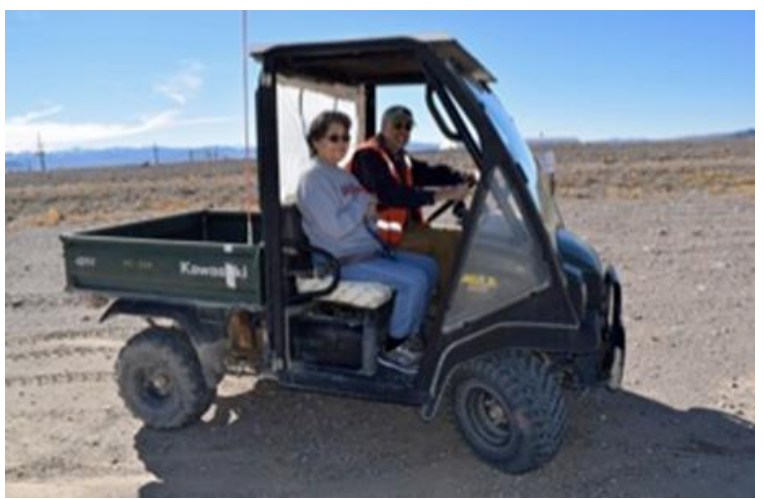

Figure 3. Numic spiritual adviser with $\mathrm{M} \& \mathrm{O}$ contractor staff on a site visit at the February 2017 Spiritual Land Preparation and Field Plan Development Meeting.

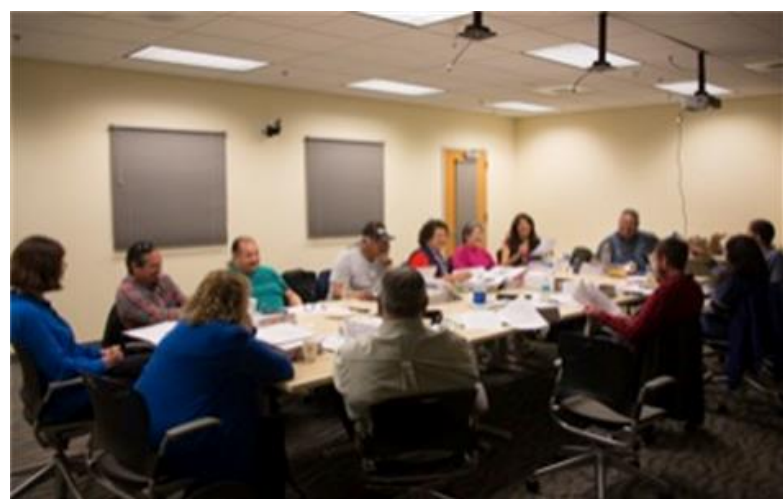

Figure 4. Tribal Revegetation Committee, PSU, and DRI participants during February 2017 Spiritual Land Preparation and Field Plan Development Meeting.

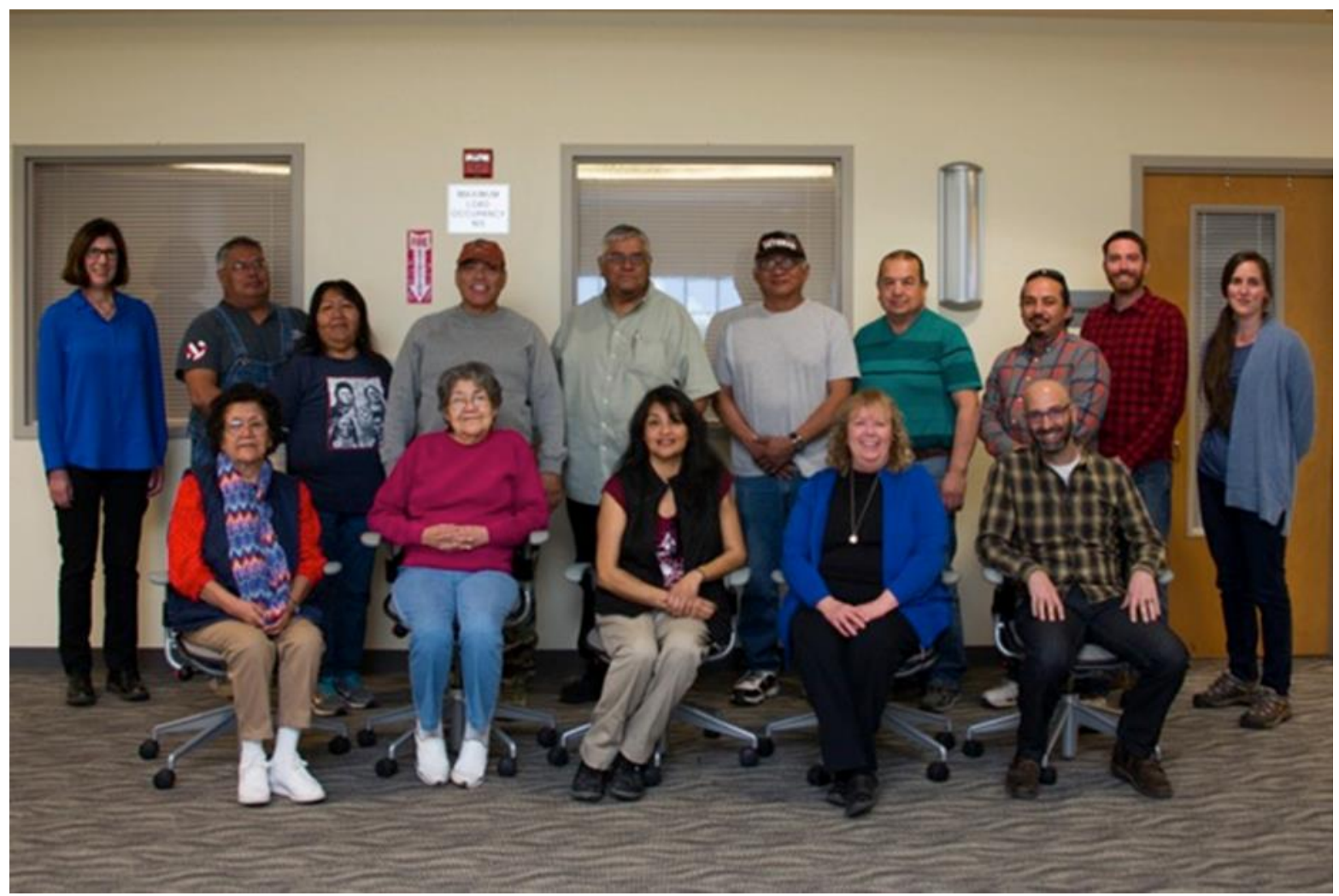

Figure 5. Tribal Revegetation Committee, PSU, and DRI participants in the February 2017 Spiritual Land Preparation and Fieldwork Plan Development Meeting. 
The greatest challenge to project success was the unnatural landscape itself. The revegetation area is an intentionally designed, raised, gently sloping landfill or "island," surrounded by a road and a fence, with legacy low-level radioactive waste buried beneath the soil. The design of the waste cell was based on the safe disposal of waste. The landfill was capped with a soil cover extending above the original grade. The success of the cap closure depends on successful revegetation. Another challenge was that seeds and outplants for the revegetation study had to be obtained from outside sources in Arizona, even though the TRC emphasized the importance of collecting seeds and source transplants from an area near the 92-Acre Area. A TRC member stated, "I would still like to see the plants be collected from this area and not another area. It is important to have a mother plant to overshadow and protect, and help the children to grow. Transplants and seeds will have that relationship of growing together. It is also important to collect seeds and transplants in the correct season."

Using outplants from outside locations was required because of availability and scheduling. Phoenix, Arizona, was identified as a similar geographic area to the NNSS where desired plant species could be obtained for successful results. However, the TRC described the importance of plant and soil proximity as critical considerations for revegetation success. These site-specific factors were not considered in the three unsuccessful attempts to revegetate the 92-Acre Area because it was thought that all land is the same and should respond accordingly.

During the course of identifying culturally appropriate methods to revegetate the test plots on the 92-Acre Area, the TRC learned they would be unable to conduct the actual planting themselves because of labor agreements and RWMC policies related to soil disturbance in accordance with DOE regulations and the FFACO. Building on the progressive nature of the project, the TRC explored ways to provide limited cultural insight to contractors who carried out the planting process. Because of the restricted nature of access to the NNSS, special arrangements were needed for the TRC to access the NNSS and more specifically the RWMC. The RWMC has stringent guidelines to enter the area that require daily safety briefings before entering the 92-Acre Area. Furthermore, the location is within the RWMC that supports active disposal activities, which includes the presence of large trucks and heavy equipment. Radiation briefings were mandatory but certain adjustments to safety regulations were made to ensure the TRC had the opportunity to perpetuate relationships with the 92-Acre Area and test plots. Specifically, waivers for some personal protective equipment (PPE) requirements were made but safety vests and protective eyewear were distributed to TRC members.

The TRC described the importance of serenity to conduct special prayers and related activities. Construction traffic and noise from heavy equipment created access and serenity challenges that influenced the limited Tribal interaction that is necessary to establish relationships with the land and nurturing the plants as they grow.

Another challenge included site preparation methods, such as culturally compatible burning of the non-native plants to create nutrients for the soil (as suggested by the TRC). Regulators prohibit any burning at the RWMC, and therefore modified approaches were required. The TRC also noted challenges associated with working with unnatural, raised topography at the 92-Acre Area combined with artificial perimeter fencing, which hinders 
animal migration and interaction with the land, preventing natural turbidity to occur on the landscape. The TRC described the erratic rainfall and attributed drought conditions to climate change.

During the project, the TRC observed a barren no-growth zone within the 92-Acre Area from unknown causes that prevented the TRC from fully understanding and communicating with the land. The TRC discussed the possibility of additional no-growth zones on other caps or near the 92-Acre Area. In the words of a TRC member, the land "looks like it is all good except for the part that is all jacked up [no-growth zone]. That area has bad soil. Probably that soil was not a topsoil that has organic materials-so it's sterile dirt. The soil needs to have food for the plants." It is important to note that the TRC members consider this area a significant obstacle for revegetation. Based on recommendations by the TRC, soil samples were taken in 2019 from both the no-growth zone and an adjacent test plot supporting healthy plant growth. The results suggested less extractable microbial DNA in the no-growth zone, and some differences in nutrient content and microbial community structure (presented in the 2019 annual project report). Additional soil testing and analysis of this nogrowth area was beyond the scope of this study and should be conducted to better understand soil conditions in response to this revegetation obstacle.

Lastly, the COVID-19 pandemic significantly altered field observation methodology and reduced the number of Tribal participants and interactions in FY20 (see below). As a result, the TRC modified their methodology by limiting monitoring involvement in response to NNSS access restrictions and instead shared updates and data in a virtual format. The group evaluated the revegetation progress using photographs and discussions with a TRC member and the DRI project ecologist who were able to continue data collection. This lack of Tribal participation during FY20 abruptly and unexpectedly forced modifications to the spiritual management component of the project and created obstacles in communicating in person with the TRC. Despite these challenges, according to the TRC, there remains clear evidence of revegetation success at the 92-Acre Area. According to a TRC member, "the plants are adapting to the landscape and working around the challenges. This is similar to the resilience of Tribal people."

\section{The Land is Alive, Has Feelings, and Needs to be Personified and Experienced}

Understanding how the TRC members relate to the land in general and the specific test plots provides integral context for the research design and how the field observation methodology was developed. Here, we describe Tribal perceptions relating to their ancestral lands that include the NNSS and specifically the 92-Acre Area. This contextualization helps show the importance of the revegetation study results and further justifies the guiding principles and recommendations shared in the conclusion of this document.

Collectively, Nuwu, Newe, and Nuиmu view the land as a living, sentient being with feelings and purpose. The land is interconnected and personified with human characteristics and with emotions. It needs to be experienced to be fully understood through "learning and doing." This tacit knowledge, which is common among Indigenous peoples, does not need to be stated to be learned (Hill et al., 2020). It is emotional, affective, based on feelings from the senses, and learned through experience (Zent, 2012; Berkes, 2012). This knowledge is born into Numic peoples and is understood at specific times in their lives, and further nurtured by their elders and life experiences. A TRC member explains how this tacit 
knowledge is learned in the following way: "I think it [knowledge of the land] is embedded into us as our birthright. Always being taught from day one, lookout for this, watch out for that, protect this...."

By contrast, Western science is implicit knowledge, which can be measured and generated or replicated in an external setting, such as a laboratory or classroom (Hill et al., 2020). The results of the revegetation study are an example of implicit knowledge, in which information is impersonal and can be abstracted from its context, whereas tacit information cannot. Consider the difference in learning how to grow garden vegetables from a book compared with learning through experience in one's own garden and gaining knowledge from the tangible experience.

This study incorporated different types of information to demonstrate revegetation success. Some of the information is tacit, such as field experiences by TRC members over the two-year planning period and three-year revegetation study. This knowledge builds on previous knowledge incrementally learned through observation or experience. Other information is implicit, such as the empirical (or quantitative) results, which are only a snapshot of a three-year period with spiritual management and Tribal interactions governing the process. A TRC member explained the difference between tacit and implicit information in the following way:

Everything's technical [implicit information]. Everything is written down. Everything is measured...they're just measuring it to see what happens. The Tribal way [tacit information] is like you're with it, you're talking with them [plants]. You're hopefully saying good things and connecting with the land and the plants that we're working with...the [Tribal] way would be spiritual or connecting with the plants.

Clearly, there is strength in combining different types of information and allowing researchers and participants to verify the validity of their findings by comparing multiple types of data (Hawkes and Rowe, 2008; White, 2002; Blaikie, 1991). Assembling information from TEK and Western science makes results and solutions more holistic, especially when addressing complex environmental problems (Hill et al., 2020). It is possible to incorporate both types of knowledge and achieve reliable and valid results by carefully crafting research questions, designs, and methods (Spoon et al., 2020), which are important aspects of this study that were considered carefully during the planning and implementation stages. By acknowledging the potential for blending sciences and information, this study demonstrates that tacit ethnographic information can be blended with the implicit information from the revegetation study and the combined results can be verified by the academic literature.

Numic peoples consider the land to be their relative and believe everything that relies on it is interconnected and dependent on one another, including humans. The Creator placed everything on the land with purpose and function. A TRC member explained, "...we believe everything is sacred out there and is your brother, sister, or some relative of yours. It could be anything, and I think everything [on the land] is sacred. Looking down to the little grass to the little ants and stuff like that. Everything has a purpose." Tribal interactions with ancestral lands connect the present with the ancestors who came before who provide help in life's journey. The TRC explained how the ancestors provide knowledge to help heal the land, including revegetation: "... you know that [knowledge to heal plants] is coming to you from 
those ancestors, those people that you asked to help you. And they are helping you." These human-environment relationships span the past, present, and future. They are like a spider's web, whereby disturbance to one part of the web affects the entire web or triggers a response. Each part reciprocally helps the others. This is analogous to an ecological systems perspective in Western science. However, most notably, Numic peoples consider humans an inseparable and integral part of sustaining balance according to its implied need.

Collectively, these elements are not the controllers of the system but part of it, and therefore they affect its existence. The land cannot be owned from this perspective, only nurtured.

The lands currently within the NNSS, including the 92-Acre Area at the RWMC, are storied lands with human connections and emotions that emerged at the "beginning of time when the world was new." Numic relationships with the land therefore rely on the wisdom of the ancestors, which is embedded in the landscape. A TRC member explained, "...these are storied lands. They contain trails, spiritual pathways, stories, rituals, and ceremonies. $[N u w u]$ say this is the center of the universe, deserving of respect and dignity. It's the sacred path of the Salt Song Trail, the home of the wolf, and the place of creation."

Healing the land is culturally appropriate and provides a significant opportunity for the DOE, Tribes, and contractors to work together on a common goal and sustain the land for future generations. A TRC member stated, “...it's not just us [Tribal members], everybody out there has to be part of the same way of thinking, and sharing good laughter with us and just being a group. Together. A group out there wanting good for that area, and it's received, and it's felt." Teamwork and friendships emerged that were critical to healing the land. The alliances created by this effort were the cornerstone project and serve as an example of how the federal government and Tribes can work together with different perspectives to fix a complex multifaceted problem.

\section{Healing the Land with Respect and Patience}

Numic peoples know it is their responsibility to heal the land when it is out of balance (Figure 6). It is a responsibility that they have been charged with by the Creator. A TRC member explained, "...it's our responsibility. We are the voices for all of this. We are supposed to be here interacting. They [the plants] need to feel our presence. They bring us songs and messages. They are the true keepers of our culture. When their voices got taken away, they still understood us, and we still understood them. A Numic spiritual leader reiterated, "...we believe the earth is where future generations arise from. The act of saying special words to the Creator for the land is mighty and there are those that do this because it's their responsibility as stewards for the plenty that was given them."

Land on the NNSS and within the 92-Acre Area are considered "sick" and "out of balance" from the lack of Tribal interaction, nuclear testing, and radioactive waste storage, among other disturbances (Spoon and Barcalow, 2016). A TRC member who has been collaborating on DOE projects for more than three decades poignantly explained this reality at the onset of the project:

The older folks talked about what was happening with the big flashes and explosions in the morning. We said they are trying to make the night into day. See birds fall out of the sky, animals die. We had to be careful. We didn't know what was going on, just creating sickness. Making day and night sick. I remember how people were praying 


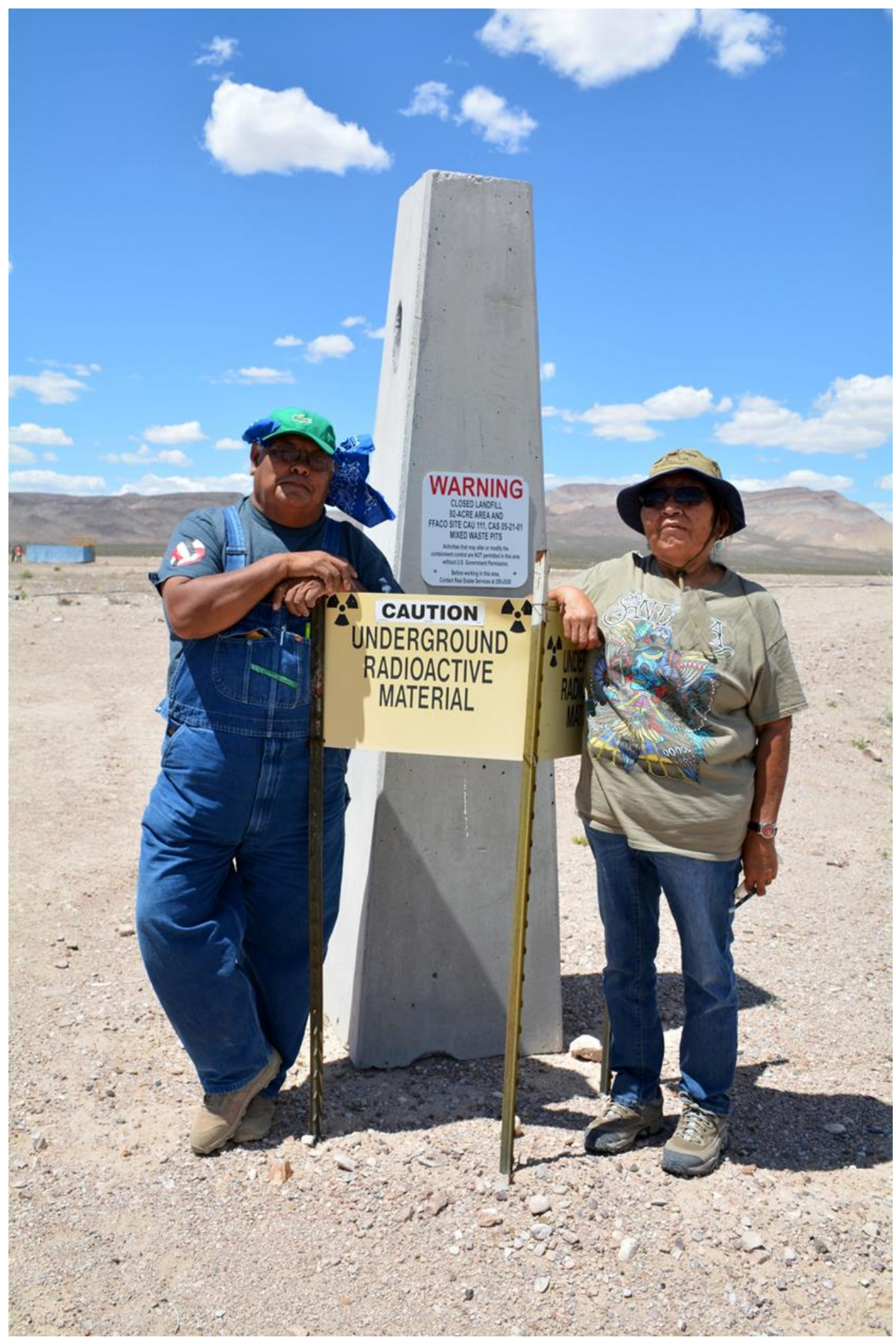

Figure 6. Tribal Revegetation Committee members reinforce their responsibility to heal the land at Radioactive Waste Management Complex (RWMC) Area 5 "no matter what condition the land is in." 
to make it go away. It got very emotional. People got run out. It was a bad time and experience. For us to come here and rely on trust is difficult. It was a sad time because this is our land. This [revegetation project] has been a successful and took a long time for us to get here.

Consider this additional statement from a TRC member about the land at the 92-Acre Area: "The lands have been worked over by heavy equipment and compacted by trucks and traffic, plus with all the testing done in this area; all the nutrients have been stripped from the soils. Microbes are needed in the soils to promote growth." When the land is sick and out of balance, people are sick and bad things happen.

The TRC shared the healing of the land and revegetation process. A TRC member explained, "...the land heals through the plants. As the plants grow, they're also releasing their energy, ... and they also bring in the wildlife, it's that connection, that cycle."

When nuclear testing began, Numic peoples were restricted for decades from visiting the lands on the NNSS, which are considered their relatives, preventing them from tending to their healing and sustaining the balance of the land. Tribal people are the caretakers of the land no matter what condition it is in. The land and everything on it (plants, animals, insects, water, etc.) needs to feel Tribal footsteps, receive offerings, and hear Tribal prayers, languages, and laughter. A TRC member stated that the 92-Acre Area "needs our songs and our prayers and our presence and our laughter." A TRC member added that "using our traditional knowledge and our traditional ways, prayers, our presence, our language out there. Bringing things back to life because they were so used to hearing everything constant until people were driven off those areas... and you know...the land never forgets, and it's a good thing we don't either."

Disturbed lands call out to their Numic relatives to heal through consistent and ongoing Tribal interactions. The interactions help the land "wake up and respond" to healing. The Tribes revive the land with memories of those who came before them. A TRC member shared, "I see us putting plants back into nature and seeking harmony, and that's what it's all about. An ecosystem starting from beginning again, and we are helping." Another TRC member added, "...we're actually connecting. We're actually on the land where we're supposed to be." Therefore, the Tribes are not involved in this effort to "prove a point" but rather to heal the land because it is lonely and neglected. Healing the land through spiritual management and continual Tribal interaction is considered an essential pathway for revegetation success over low-level radioactive waste that is buried below. The land is considered more powerful than any disturbance it has endured. A Numic spiritual leader explained, "You'll never see the power taken away from here even after all that has happened in southern Nevada because of the place's exclusive power."

The values of respect and patience guide Tribal interactions with the land. Numic peoples treat everything on the land with respect through interactive relationships. These relationships are similar to human relationships, which rely on trust and must be continually nurtured to thrive. The following is an example of how a TRC member describes making relationships with medicinal plants: "... a plant is a living thing and to me, if I go out, and I'm getting medicine, and I know where it's at, I tell the plant what I'm doing there... and because they are a living thing, I believe that they will hear and help us with what we're out there to do...." 
Numic peoples have had ancestral and traditional ties to a broad region that includes the lands surrounding the 92-Acre Area from the beginning of time, when the world was new. Tribes consider their contemporary relationships with the 92-Acre Area as an extension of the ongoing connection that evolved from collective prayers shared at the beginning and throughout the duration of the Tribal Revegetation Project. These prayers were then reinforced through consistent Tribal presence and interactions (Figure 7). A TRC member described the role of prayer for Numic peoples in the following way: "... whenever a Native American is doing something, we have prayers... if it's a plant gathering, if it's hunting, anything that we're taking off the land, we'll pray for the land. We're praying for the plants. We 're thanking the Creator for giving us what he's giving us, and to help with regrowth." A TRC member detailed the tenets of the specific prayers made at the 92-Acre Area at the onset of the revegetation effort: "The blessings were concerning the actual land itself, and the plants, and talking with them, helping them to understand...that we would like to help you by being here, connecting with you and how the involvement would be...."

These relationships create an exchange of energy between humans and the environment. This energy is exchanged with each and every plant as they emerge from the soil. A TRC member described this process in the following way: "...everything has energy, everything is energy, everything is connected...we exchange energy with plants not only through emotional energy, but also through our breath. And we share that breath with them, so they give us our breath." The following is another example from a TRC member describing establishing connections with plants similar to making relationships with humans: "... what I do is when I go to areas, I introduce myself to the lands. In my language I say who I am, where I'm from, who my parents, my grandparents, my great-grandparents are. What lands I come from and the reason why I'm there on that land. I'm introducing myself and my purpose for being there...it's just like a person."

Because these relationships are established, learning and familiarity occurs between people and the land. This understanding is considered critical to identifying what is needed for environmental healing, which in turn promotes revegetation success over time through the values of respect and patience. A TRC member described how he made a relationship with the 92-Acre Area after offering prayers and songs at the onset of the project: "...the land is always in our prayers and always in our thoughts for that healing and it was more than just, 'we'll go out there, pray and then leave. '...we can feel that she needed our prayers, she needed our word, she needed our song, she needed her prayers."

The Tribes view the land similar to a sick patient that needs to be monitored continually to make sure they heal properly. Comparatively, Tribal involvement is vital to heal the land. The prayers made on the land need to be reinforced through consistent Tribal interactions to sustain their healing power. A TRC member explained, “...our prayers would stay out there, but they won't be reinforced without us coming out every so often...they wouldn't be as strong or as powerful." The TRC members indeed take pride in their accomplishments associated with raising plants in the test plots from seed, as parents do when raising their children. Equally, both need to be nurtured to ensure they develop properly. 


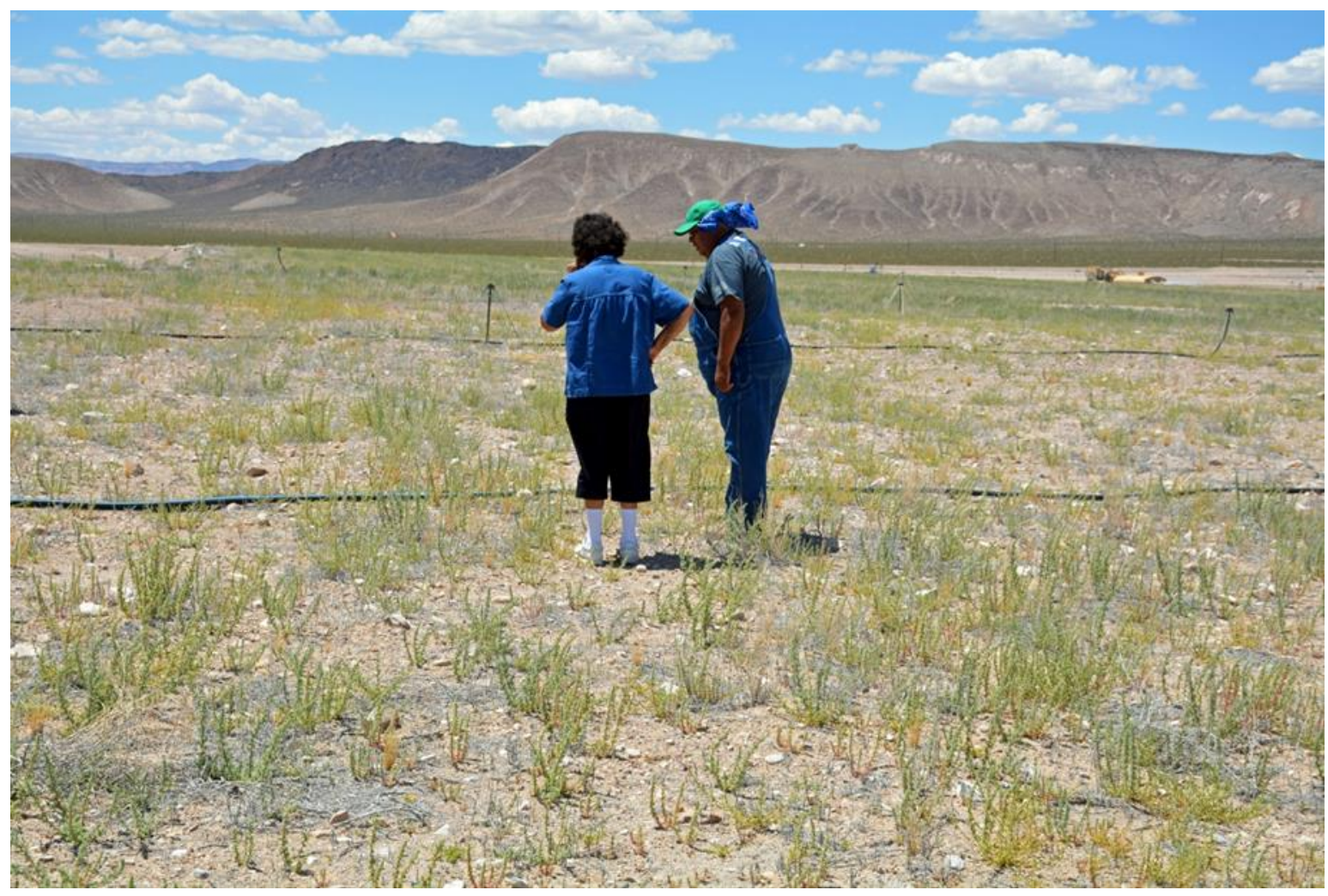

Figure 7. Tribal Revegetation Committee members interact with the land and identify non-native plants in the 92-Acre Area at the Radioactive Waste Management Complex in Area 5 in June 2016.

Patience is a critical component to any effort, including healing the land. From a Tribal perspective, the land cannot be rushed and only the land can heal itself with the assistance from Tribal relatives. Tribes engage in spiritual management and follow appropriate cultural protocols to make things strong. The TRC members feel the three previous unsuccessful attempts to revegetate all or part of the 92-Acre Area did not yield the desired results because of the contractor's unfamiliarity with the complex relationships between the land and the personalities of the plants, which reveal themselves when properly respected. Unlike previous attempts, the TRC members established an interactive foundation and stimulated the healing process on the test plots and within the 92-Acre Area. Tribal people know it is essential to have a good heart and mind and speak the language of the land. The TRC members noted the land is fragile but resilient if given the time to evolve. Without spiritual management or Tribal wisdom, the land will struggle.

\section{Spiritual Management and Following Cultural Protocols}

Numic peoples use spiritual management to guide their environmental relationships when healing the land. This form of management begins with the individual and reverberates outward. A TRC member describes spiritual management in the following way: "...spiritual management starts first from the person within themselves, and if they have that calling, of that land, will take that lead, and in doing so, then when they go out there as a group, some people will step it up a level because that land will call to them because they have a certain 
something within them inside that can provide." The land had previously "heard nothing but Indigenous languages of the people that came before." Spiritual management helps restore and reinforce integral Indigenous human-environment relationships that were interrupted by ground disturbing activities, such as low-level radioactive waste disposal and the COVID-19 pandemic. Spiritual management is specific to the needs of each site and must be tailored to the condition of a particular area. The level of spiritual management required for the test plots and the 92-Acre Area was particularly high because of the unnatural and disturbed landscape (Figure 8). To make relationships with the land, a person must first have a positive mind and healthy heart. Making prayers, sharing offerings, singing songs, and speaking in Numic languages are essential to facilitate healing. A TRC member described the process in 2017 , “...we believe our songs and prayers have energy that can transform and heal. Everything we put out there has effects. We could feel the land is out of balance, it was sick. It wasn't able to hold life as it should. It looked like a desolate land."

Spiritual management includes touching the land as an appropriate greeting, letting the land feel the footsteps and hear the voices and laughter of its Indigenous relatives that suffer from isolation and yearn for a reunion to heal. A TRC member explained, “...it is important for Indian people to be out there for the land to hear our voices, to hear our footsteps and our prayers...to be there to help the land, to heal the land, and cause the animals to come see us, lizards, rabbits, antelope. We want to be there. We want to be on our land."

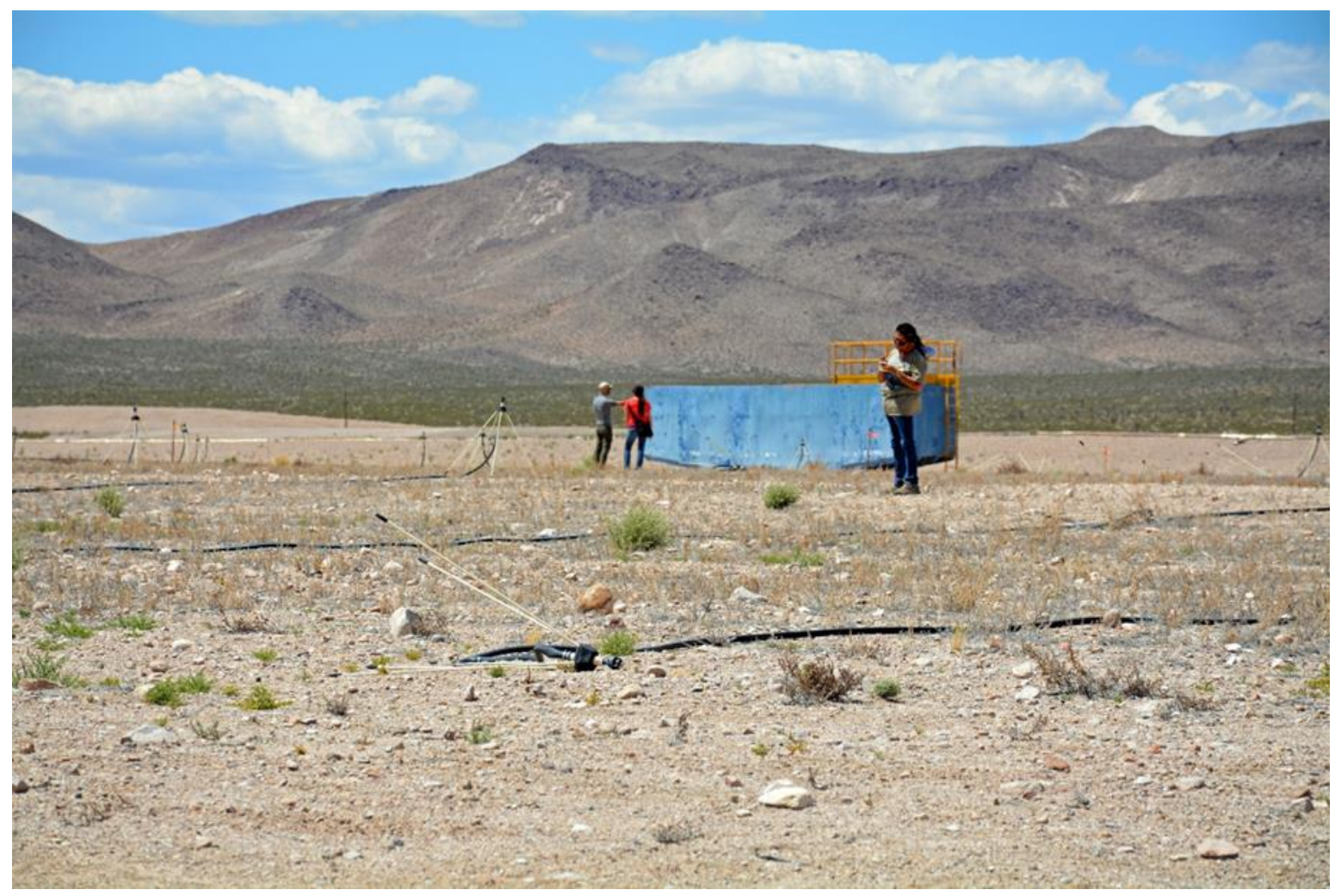

Figure 8. A TRC member evaluates and interacts with the 92-Acre Area in 2016 at the onset of the revegetation. Notice irrigation equipment used from previous revegetation attempts and the presence of limited vegetation. 
Spiritual management requires faith, trust, and an understanding of the unseen to face the challenges ahead. A TRC member shared that "they [non-Indians] need to have an open mind and an open heart. They need have to have a willingness to accept things that are not seen, because that's what faith is." The land will only heal if those involved believe the effort will be successful. This belief includes creating and sustaining relationships with the land and everything on it. Actions for this process encompass bringing spiritual leaders to a site to share prayers and songs before any healing can begin. These prayers and songs are embedded in the land and need to be reinforced through ongoing Tribal involvement. The land never forgets these interactions and responds positively when respected and approached in the correct way.

A TRC member described the power of these prayers and songs and how people need them for strength and healing. He stated, "...the songs never leave, and the songs still remain strong. They're still there; it's just that we have to reawaken the songs to bring them back to sing it all over again." Building on this unique Tribal perspective, the following is a description of the prayers that were initially left at the 92-Acre Area by a TRC member: "... when the elder was singing, he was facing to the west, I could hear his song coming from the north. And his song, came closer and closer. When he finished and was looking at everybody like that, the song was right behind him, on the west side."

Tribal participation must therefore start at the beginning of any revegetation effort or it will not be successful or the land will remain unbalanced. A TRC member explained that the project was successful "because we believed in the spiritual aspect. We're asking for permission and asking for all the other aspects that are incorporated in doing it politically, traditionally, and culturally correct." A TRC member further added, "...my favorite part [of the project] was when we were all together at the beginning, everybody... [the land appeared] barren, but seeing an ant, and I'm like okay. An ant can live here, things can grow and prosper...I took that as a good sign of just needing attention ... I felt really positive about it."

Tribal spiritual management must be engaged to heal the land according to culturally mandated protocols. The steps include special prayers on the land from the beginning and maintaining consistent Tribal interactions throughout the process. According to the TRC members, healing the land is a process and does not have a specific end point. In the words of a TRC member: “...if you want to be good at what you do, you can't miss a step. You can't leave things out, there's no such things as shortcuts." Following all of the traditional steps is considered a critical component identified by the TRC members for revegetation success. A TRC member explained, “...there's a process and it has to be followed...there are rules and if you're traditional, you follow those rules. I remember my grandma yelling at me, 'you're traditional, aren't you?" The TRC members consider spiritual management an integral component to any revegetation effort. A TRC member commented that the "key with this project is that we need to treat the land right and get it back to being healthy in order for this project to work."

In the case of revegetation, leaving out any of the necessary steps will negatively affect the outcome. The steps include:

1. Having spiritual leaders on the land before any revegetation actions occur.

2. Sustaining Tribal interactions throughout the revegetation process to create relationships and enact spiritual management. 
3. Having individuals responsible for carrying out tasks that the TRC members are not permitted to do because of regulations participate in cultural awareness training with the TRC members.

4. Monitoring contractor activities to ensure proper protocol is followed so that it can be carried out properly in the absence of Tribal people.

5. Future revegetation, requires the steps identified and/or recommended by the TRC to achieve meaningful results (see the "Guiding Principles" and "TRC Recommendations" sections for additional information and next steps).

\section{Numic Collaboration}

The 16 American Indian Tribal nations and affiliated groups with cultural and historical ties to the NNSS have continuously expressed interest in revegetation efforts on the NNSS for more than 30 years (Stoffle et al., 1990; American Indian Writers Subgroup, 1996; Stoffle et al., 2001). The TRC members expressed the importance of bringing multiple culturally affiliated Tribes together at the 92-Acre Area so that the land can hear prayers, languages, laughter, and other forms of communication from its relatives. Therefore, this project uniquely combines Tribal knowledge from three ethnic groups ( Nuwu, Newe, and Nuитu) representing 16 Tribes. It is universally understood that the land is sick and out of balance, and therefore requires the power of many Tribes. Bringing Nuwu, Newe, and Nuumu together provides more power to heal the land, which it needs because it is so sick. The prayers from multiple Tribes give the land extra puha (power) to heal. A TRC member explained, "...multiple prayers from various Tribes bring in a new level of prayer, and it is a combination of all Tribes and their prayers in their own ways, and brings in their ancestors and spiritual side, to be included...sometimes it's good to have extra, a little help out there since the land is so sick."

The positive minds and healthy hearts brought teams of Tribal members and project collaborators together to assist with the healing. A TRC member explained, "...once you put positive energy in anything, it will transform, and they [the plants] know this." Working in teams is considered vital for revegetation success. It helps in the rigorous collection of data and strengthens relationships between people and the land, and reinforces prayers that have been left previously. According to a TRC member, each field observation session "should have three monitors, one from each ethnic group [Nuwu, Newe, and Nuumu]. We don't want to leave anyone out. Each brings their own set of knowledge. Consistent with the composition of the group." After two years of planning and three years of reestablishing relationships with the land, the TRC members expressed, "....we all gave a little bit of ourselves out there to make this happen. And I think that's why we continue to want to know how it's doing. We want to see how it's doing because it goes back to that responsibility; we're hoping that it heals... and we are learning how to heal it together."

Building on the mutual respect and collective wisdom of TRC members and spiritual leaders is vitally important to solving complex problems, such as developing a vegetative cap on a radioactive waste disposal area. A TRC member shared the following perspective about how Tribal representatives learn from one another during project activities: “...you learn so much from the other Tribes of their own language, of what things are called and the purposes of them. And the purposes of the plants we planted. We learned the importance of them and the traditional knowledge of those plants and what medicines they can be." A TRC 
member added that "it's very unique you put such a diversified group together-including PSU, DRI, and Tribal participants-it's so diverse. Even though we're all from surrounding Tribes...our ideas and how we work together-it seems to be very powerful."

\section{COMPLETED PROJECT TASKS PER FISCAL YEAR}

The tasks completed in the monitoring years of the project (FY18 to FY20) are summarized below:

- FY18: Four tasks presented in the Fieldwork Plan (Spoon and Barcalow, 2017) were implemented: (1) fall/winter planting, (2) field observation (monitoring) training, (3) spring planting, and (4) field observation sessions (six sessions total). All activities were carried out by TRC members in collaboration with the DOE EM NV, DRI, PSU, Mission Support and Test Services (MSTS), Navarro Research and Engineering, and Soil-Tech, Inc., a subcontractor through Navarro that specializes in desert revegetation projects.

- FY19: Two tasks presented in the Fieldwork Plan (Spoon and Barcalow, 2017) were implemented: (1) support annual field evaluation meeting and Tribal blessings for culturally appropriate land preparation, and (2) field observation sessions (eight sessions total). All activities were carried out by TRC members in collaboration with the DOE EM NV, DRI, PSU, MSTS, and Navarro Research and Engineering.

- FY20: Two tasks presented in the Fieldwork Plan (Spoon and Barcalow, 2017) were implemented: (1) convene the annual field evaluation meeting along with Tribal blessings for culturally appropriate spiritual management and (2) field observation sessions (four modified sessions were completed, with three additional sessions cancelled because of COVID-19 pandemic complications [see section below on COVID-19 adaptations]). All activities were accomplished by TRC members in collaboration with the DOE EM NV, DRI, PSU, MSTS, and Navarro Research and Engineering.

\section{ANNUAL FIELD EVALUATION MEETING AND BLESSINGS}

Annual meetings were identified as critical to reinforce Tribal relationships with the land through spiritual management, share preliminary results, and elicit feedback. Each year the TRC, DRI, and PSU visited the test plots at the 92-Acre Area and provided collective field observations as scheduled to support Tribal interactions with the land. The EM NV and the State of Nevada attended annual meetings in FY18, FY19, and FY20 to observe progress and receive feedback from the DOE and the Regulator. The meetings were extremely valuable for exchanging ideas and identifying discussion points needed to address the empirical results and how they interface with unique Tribal perspectives. Attendees collectively shared lessons learned to more efficiently conduct field observations and adapt to the land's changing needs, and more candid conversations were had as they shared their experiences. Preliminary results could also be vetted and checked for validity by comparing the results with Tribal observations and experiences. 


\section{MODIFICATIONS TO FY20 ACTIVITIES BECAUSE OF COVID-19 PANDEMIC}

The COVID-19 pandemic brought several unexpected challenges to the project (as noted in Table 1). The TRC members were not permitted access to the 92-Acre Area during 2020, which created challenges and limited opportunities to interact with the landscape, without explanation to the plants and the land. This interrupted spiritual management and connection and may have inadvertently affected the number of plants, animals, and insects observed on site in FY20. A TRC member and Tribal Spokesperson for the 16 American Indian Tribal nations and affiliated groups with cultural and historical ties to the NNSS conducted a limited number of field observation sessions with assistance from the project ecologist. The reduction in participants conducting field observations no doubt impeded the ability to provide observations of the wildlife present. Accordingly, a TRC member stated, "I think we are limited with participation and that is going to have an impact on our results...I would like to see if we can get one more Tribal member to participate for the wildlife and insect count. That is a part of the ecosystem and it's very important to document." Consider also this statement from a TRC member about modifications to the FY20 field observation schedule because of COVID-19 restrictions: "I think not being out there is actually a discontinuation. We're disconnecting from those plants from our project from Mother Earth. We're not out there you know to help reinforce the growth of these plants." These important perspectives became the impetus for holding virtual meetings so that the TRC, DRI, and PSU could receive status updates while forwarding project outcomes. Although the meetings were an important adaptation for discussing project activities, it was unanimously agreed that the virtual format is no replacement for in-person meetings and direct experiences on the land.

\section{TRIBAL METHODOLOGY}

The project's Tribal methodology guided all aspects of the effort. It began with forming a gender-balanced TRC representing culturally and historically affiliated Numic Tribes that met regularly to share their collective knowledge and wisdom for healing the area. The TRC members identified and interviewed spiritual leaders from their respective Tribes to establish a foundation for expanding the project's collective knowledge. Integral to the methodology are spiritual land preparation, species and outplant selection, and determination of appropriate and compatible planting seasons and techniques. Therefore, the TRC created a research design with indicators for a revegetation study (see below) in tandem with the project anthropologist and ecologist. Spiritual leaders from multiple Numic Tribes shared prayers with the land to properly prepare it for the impending ground disturbance and revegetation activities. These prayers were not only directed toward the 92-Acre Area, but also the broader landscape. Combining Numic prayers made the prayers stronger and compounded their power to heal, which reinforces the importance of involving multiple Tribes. Relationships with the land, plants, animals, and environment were sustained through consistent Tribal interactions to add balance to and sustain the land. The interactions included fall and spring planting seasons in addition to insight through cultural awareness training and on-site monitoring of contractor activities during test plot preparation and planting. The TRC conducted monthly or quarterly field observations, and participated in debriefing meetings and annual meetings to discuss progress and examine results. During these activities, TRC members collected empirical information, conducted spiritual management, and nurtured their relationships with the plants and other environmental components throughout the 
project. After three-years of observation and data collection, the TRC, project anthropologist, and ecologist discussed the interpretation of the empirical results from a Tribal perspective. The TRC shared complex ethnographic information to expand the results of the empirical revegetation data.

\section{Summary of Tribal Interactions FY16 to FY20}

Tribal interactions remained consistent throughout the five-year span of the project. Figure 9(a) shows the number of monthly Tribal interactions by fiscal year between FY16 and FY20. Tribal interactions began with spiritual land preparation in FY16 and early FY17. Planting and field observation increased the number of interactions significantly from FY18 to FY20. Figure 9(b) shows that the average number of Tribal interactions between FY16 and FY20 equaled 5.5. Focusing on FY18 to FY20, the average Tribal interactions increased to eight. The three canceled field observation sessions and virtual meetings expectedly affected the number of Tribal interactions in FY20, which would have been higher than five without these constraints and modifications. The TRC members consider the number of Tribal interactions in FY18 and FY19 (9 and 10, respectively) to be an appropriate number of interactions to carryout spiritual management at the 92-Acre Area.

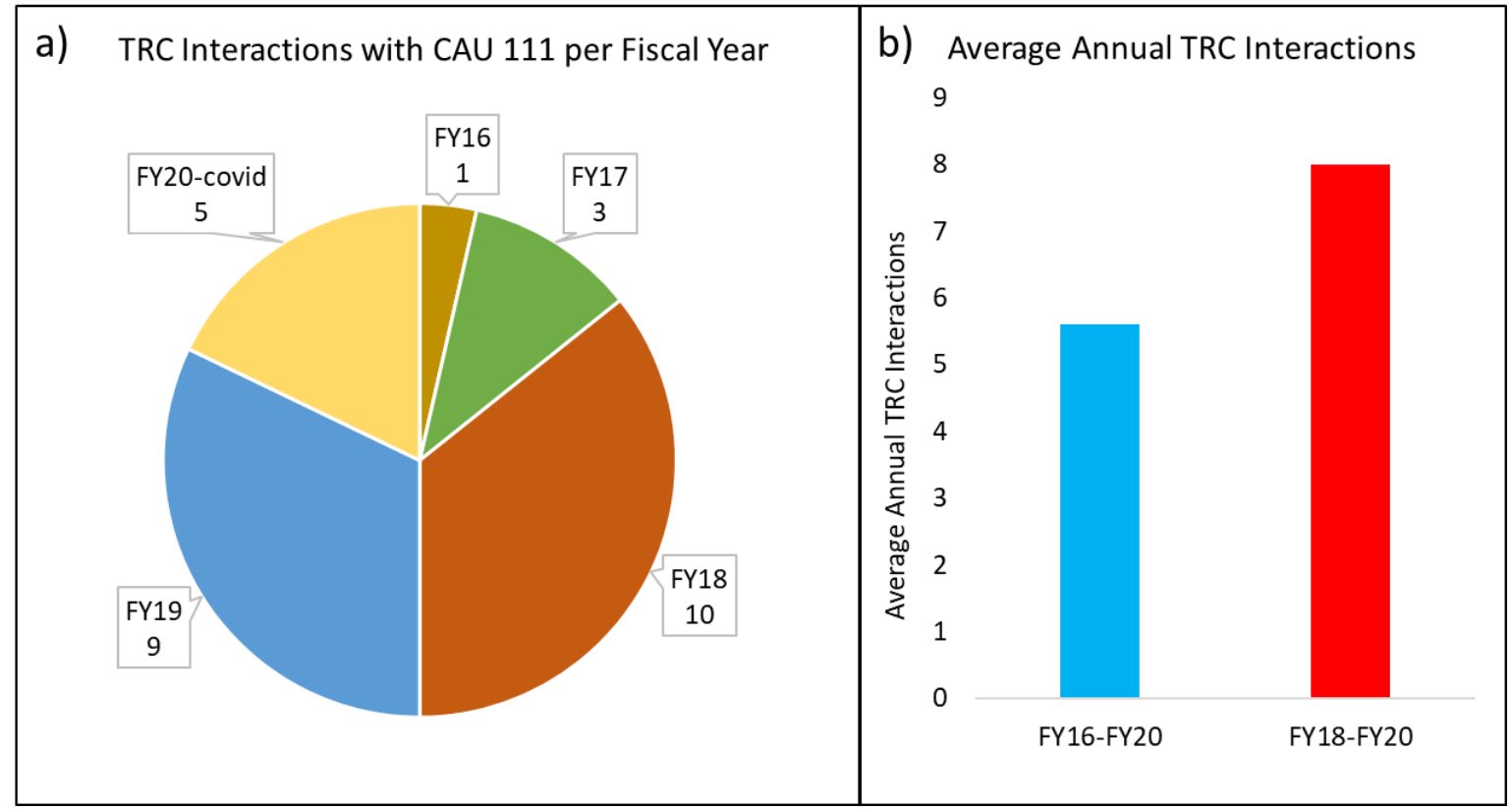

Figure 9. Total TRC interactions with the Tribal Revegetation Project site at the 92-Acre Area per (a) federal fiscal year and (b) annual TRC interactions averaged across the entire project (FY16 to FY20) and across the intensive planting and monitoring years (FY18 to FY20). 
Table 1. Tribal Revegetation Project activities FY16 to FY21.

\begin{tabular}{|c|c|c|c|}
\hline \multicolumn{2}{|c|}{ Fiscal Year (FY) } & \multirow{2}{*}{$\frac{\text { Date }}{\text { March } 2016}$} & \multirow{2}{*}{$\begin{array}{l}\text { Activity } \\
\text { Planning (no site visit); Collaborative Ethnographic Interviews with Numic } \\
\text { Spiritual Leaders ( } \mathrm{n}=4 \text { ); TRC Literature Review }\end{array}$} \\
\hline 1. & FY16 & & \\
\hline 2. & FY16 & June 2016 & Spiritual Land Preparation, Planning \\
\hline 3. & FY17 & Jan/Feb 2017 & Spiritual Land Preparation, Workplan Development \\
\hline 4. & FY17 & April 2017 & $\begin{array}{l}\text { TRC Presentation at annual meeting of } 16 \text { American Indian Tribal nations } \\
\text { and affiliated groups with cultural and historical ties to the NNSS }\end{array}$ \\
\hline 5. & FY17 & Aug 2017 & $\begin{array}{l}\text { Experimental Design Finalization, Spiritual Land Preparation, Plot } \\
\text { Selection, Field Observation Form Finalization }\end{array}$ \\
\hline 6. & FY18 & Dec 2017 & $\begin{array}{l}\text { Fall/Winter Planting: Cultural Competency Training, Spiritual Land } \\
\text { Preparation, Plot Preparation and Planting, Seed Preparation, Planning }\end{array}$ \\
\hline 7. & FY18 & Feb/March 2018 & Spiritual Land Management, Field Observation Training \\
\hline 8. & FY18 & April 2018 & $\begin{array}{l}\text { Spring Planting: Spiritual Land Preparation/Management, Plot Preparation } \\
\text { and Planting, Seed Preparation, Field Observation, Planning }\end{array}$ \\
\hline 9. & FY18 & April 2018 & $\begin{array}{l}\text { TRC Presentation at annual meeting of } 16 \text { American Indian Tribal nations } \\
\text { and affiliated groups with cultural and historical ties to the NNSS }\end{array}$ \\
\hline 10. & FY18 & May 2018 & Spiritual Land Management, Field Observation \\
\hline 11. & FY18 & June 2018 & Spiritual Land Management, Field Observation \\
\hline 12. & FY18 & June 2018 & Spiritual Land Management, Field Observation \\
\hline 13. & FY18 & July 2018 & Spiritual Land Management, Field Observation \\
\hline 14. & FY18 & Aug 2018 & Spiritual Land Management, Field Observation \\
\hline 15. & FY18 & Sept 2018 & Spiritual Land Management, Field Observation \\
\hline 16. & FY19 & Dec 2018 & Annual Meeting: Spiritual Land Management, Field Observation, Planning \\
\hline 17. & FY19 & Feb 2019 & Spiritual Land Management, Field Observation \\
\hline 18. & FY19 & March 2019 & Spiritual Land Management, Field Observation \\
\hline 19. & FY19 & April 2019 & Spiritual Land Management, Field Observation \\
\hline 20. & FY19 & April 2019 & $\begin{array}{l}\text { TRC Presentation at annual meeting of } 16 \text { American Indian Tribal nations } \\
\text { and affiliated groups with cultural and historical ties to the NNSS }\end{array}$ \\
\hline 21. & FY19 & May 2019 & Spiritual Land Management, Field Observation \\
\hline 22. & FY19 & June 2019 & Spiritual Land Management, Field Observation \\
\hline 23. & FY19 & July 2019 & Spiritual Land Management, Field Observation \\
\hline 24. & FY19 & Aug 2019 & Spiritual Land Management, Field Observation \\
\hline 25. & FY19 & Sept 2019 & Spiritual Land Management, Field Observation \\
\hline 26. & FY20 & Dec 2019 & Annual Meeting: Spiritual Land Management, Field Observation, Planning \\
\hline 27. & FY20 & March 2020 & CANCELLED DUE TO COVID-19 PANDEMIC \\
\hline 28. & FY20 & April 2020 & CANCELLED DUE TO COVID-19 PANDEMIC \\
\hline 29. & FY20 & May 2020 & Spiritual Land Management, Modified Field Observation \\
\hline 30. & FY20 & June 2020 & Spiritual Land Management, Modified Field Observation \\
\hline 31. & FY20 & June 2020 & Virtual Field Observation, Planning \\
\hline 32. & FY20 & July2020 & CANCELLED DUE TO COVID-19 PANDEMIC \\
\hline 33. & FY20 & Aug 2020 & Spiritual Land Management, Modified Field Observation \\
\hline 34. & FY20 & Aug 2020 & Virtual Field Observation, Planning \\
\hline 35. & FY20 & Sept 2020 & Spiritual Land Management, Modified Field Observation \\
\hline 36. & FY20 & Sept 2020 & Virtual Field Observation, Planning \\
\hline 37. & FY21 & Oct 2020 & Annual Meeting (Part 1), Results Discussion, Planning \\
\hline 38. & FY21 & Oct 2020 & Annual Meeting (Part 2), Results Discussion, Planning \\
\hline 39. & FY21 & Nov 2020 & $\begin{array}{l}\text { In-Depth Collaborative Ethnographic Interviews with } \\
\text { TRC Members }(n=7)\end{array}$ \\
\hline 40. & FY21 & Nov 2020 & Virtual Discussion on Collaborative Ethnographic Interview Themes \\
\hline 41. & FY21 & Dec 2020 & $\begin{array}{l}\text { Virtual Meeting with DOE and State of Nevada to Discuss Draft Report and } \\
\text { Recommendations }\end{array}$ \\
\hline 42. & FY21 & March 2021 & $\begin{array}{l}\text { Virtual Meeting to Discuss DOE Comments on Draft Report and } \\
\text { Recommendations }\end{array}$ \\
\hline
\end{tabular}




\section{REVEGETATION STUDY FIELD METHODS}

Before determining field methods, the TRC members deliberated on the potential challenges for the revegetation project. After considering the merits of the undertaking, the TRC members agreed to carry out a revegetation study to better understand what plants would grow in these challenging conditions at the 92-Acre Area (Spoon and Barcalow, 2017). For example, a Numic spiritual leader commented that "the development of a revegetation plan is crucial. Experimenting with what will grow in smaller plots will show what plants should be planted in larger areas. DOE should try this method before planting larger acres." A Numic spiritual leader also shared that "smaller plots should be developed and experimented with by willing individuals using different types of plants to see which plot is the most successful and healthy. It will be the basis for a start." Lastly, a TRC member shared at the onset of the three-year revegetation study that the approach would help the group "discover what plants can adapt with transplanting, soil variations, and weather changes...I believe it is a great approach to see what does work, and then we can provide data and move forward in planting the types of vegetation that can grow at the 92-Acre Area."

\section{Summary of Plot Design and Planting}

Based on multiple Tribal recommendations for conducting a revegetation study using blended methods from TEK and Western science, in FY18, a portion of the north cover of the 92-Acre Area was used to establish plots to introduce outplants and seeds. Plots were delineated cartographically using a geographic information system (GIS). A grid with $10 \mathrm{~m} \times 10 \mathrm{~m}(32.8 \mathrm{ft} \times 32.8 \mathrm{ft})$ squares was overlaid on a map of the north cover. A random number generator was used to select 30 plot locations and the locations of all the selected test plots were mapped in the field. The 30 plots were randomly divided into 5 different plot treatment types, including control plots that were watered but not seeded or manipulated (Table 2). Half of the plots were designated for the fall/winter planting and the other half were designated for the spring planting only, with the five plot treatment types applied to three replicates within each planting season (Figures 10 to 12). Soil amendment included undefined amounts of local borrow-pit topsoil added to and tilled into the appropriate plots, and it occurred without the presence of TRC or project members. Plots that received the mulch addition had $~ 100 \mathrm{lbs}$ of Kellogg Organics brand Topper Organic Plus product added per $10 \mathrm{~m} \times 10 \mathrm{~m}(32.8 \mathrm{ft} \times 32.8 \mathrm{ft})$ plot. The addition of straw occurred at a rate of two $50 \mathrm{lb}$ bales per $10 \mathrm{~m} \times 10 \mathrm{~m}(32.8 \mathrm{ft} \times 32.8 \mathrm{ft})$ plot in those plots that received this amendment. 
Table 2. Treatments used on $10 \mathrm{~m} \times 10 \mathrm{~m}(32.8 \mathrm{ft} \times 32.8 \mathrm{ft})$ plots. Each plot received one treatment type. The treatment code refers to the codes used in the tables of this report. The treatment numbers correspond to the treatment numbers in Figures 11 and 12.

\begin{tabular}{lcc}
\hline $\begin{array}{l}\text { Treatment } \\
\text { Number }\end{array}$ & Treatment & Treatment Code \\
\hline 1 & Soil amendment + Mulch & $\mathrm{S}+\mathrm{M}$ \\
2 & Straw & $\mathrm{St}$ \\
3 & Outplant + Soil amendment + Straw & $\mathrm{T}+\mathrm{S}+\mathrm{St}$ \\
4 & Outplant + Mulch & $\mathrm{T}+\mathrm{M}$ \\
5 & Control & Control \\
\hline
\end{tabular}

Each plot was fitted with eight sprinklers for supplemental watering. A Numic spiritual leader suggested irrigation decisions should mimic natural precipitation. He stated, "...plants should be watered in a manner consistent with natural rain. The type of plant that grows there does not require much water. Look at rainfall data." Although the initial plan indicated plants would be watered at 150 percent of the long-term average monthly precipitation totals, the logistics were unreasonably complicated. Instead, the plants were watered for approximately 20 minutes per watering event, until a depth of $1 \mathrm{~cm}(0.4 \mathrm{in})$ was achieved. For both the fall/winter- and spring-planted plots, each plot was watered at this rate twice per week during the first five months. After five months, watering was reduced to once per week for approximately 20 minutes. If natural rainfall equaled or exceeded $0.5 \mathrm{~cm}$ $\left(0.2\right.$ in) or air temperature was equal or below $35^{\circ} \mathrm{F}\left(1.7^{\circ} \mathrm{C}\right)$ during any week, irrigation was not conducted during that particular week. A TRC member described the Tribal perspective on supplemental irrigation. She stated, "...the plants need support for the first three years of their life, and I think it should be given to them and eventually they will stand alone. Giving them extra water in summer should be mandatory." The TRC members recommended the supplemental watering should taper off to allow the plants to adapt to the surrounding conditions. A TRC member explained that giving supplemental irrigation puts "the plants on a schedule. Nature is not on a schedule. I think if we add in more waiting time there shouldn't be a shock because the plants will already be established." 


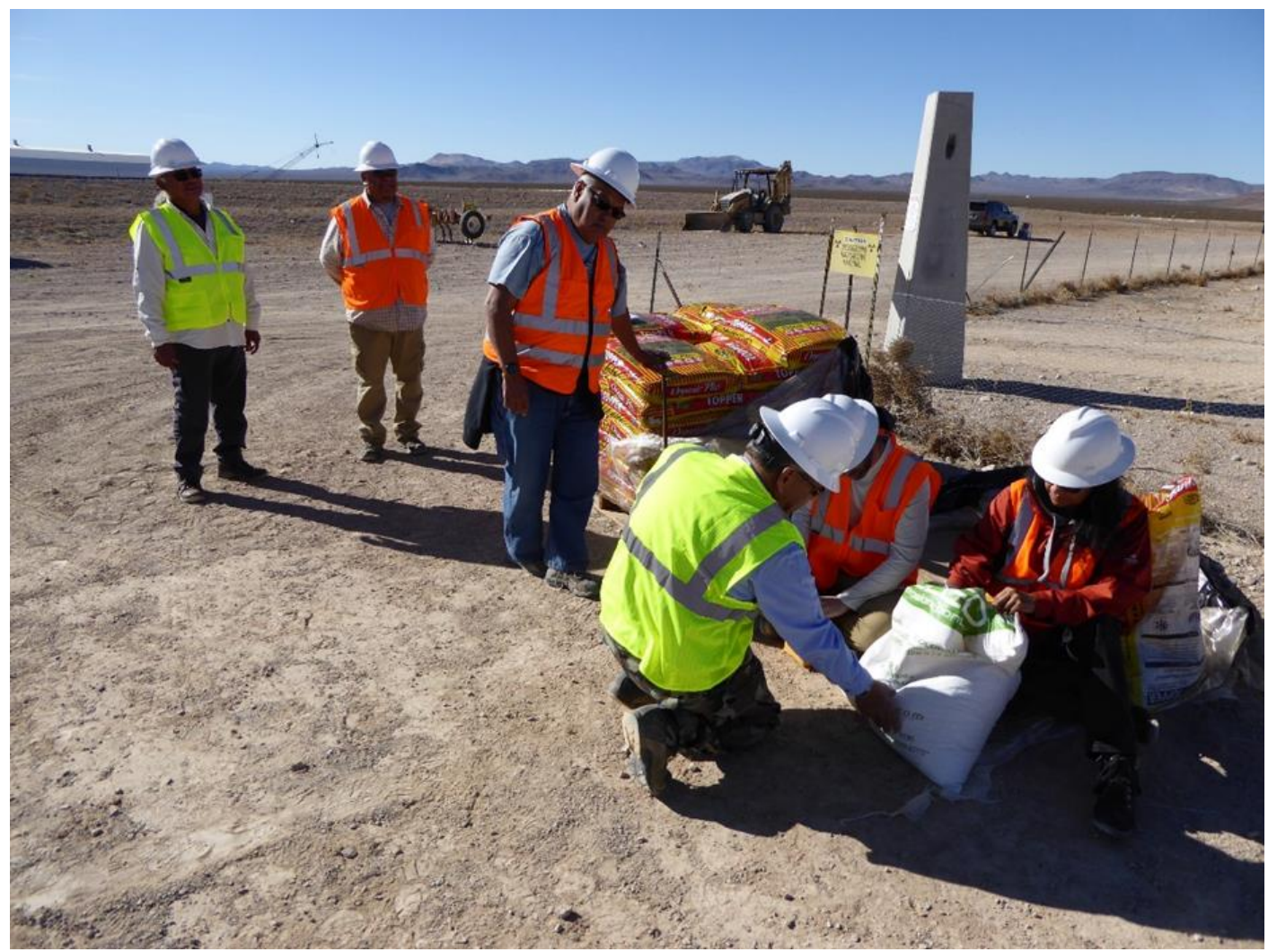

Figure 10. Fall/winter planting in December 2017. Tribal Revegetation Committee members dividing seeds for each plot in the fall/winter planting initiative.

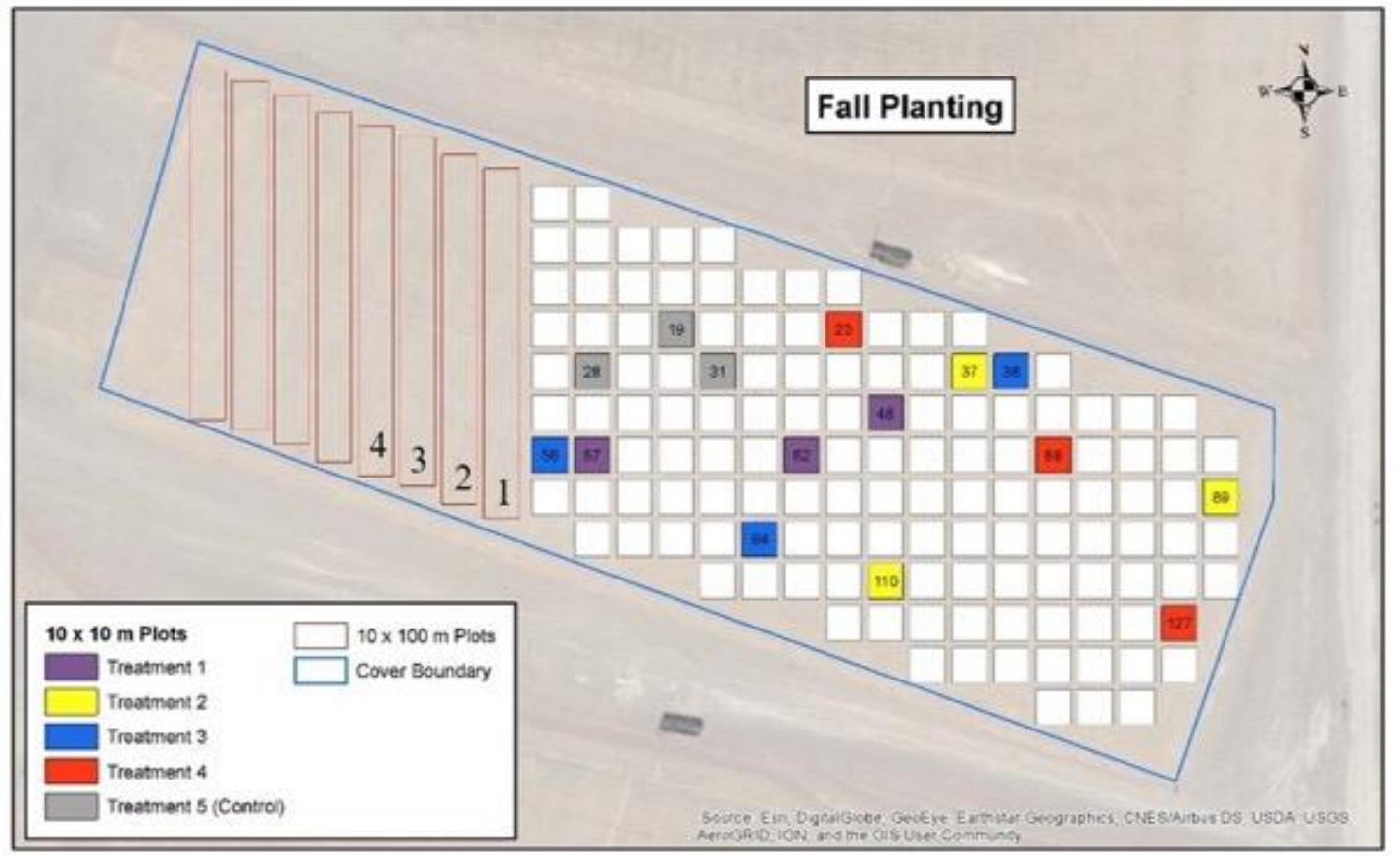

Figure 11. Plot design and location of plots planted in the fall/winter. The north-south plots on the west side of the cover are the transplant plots. 


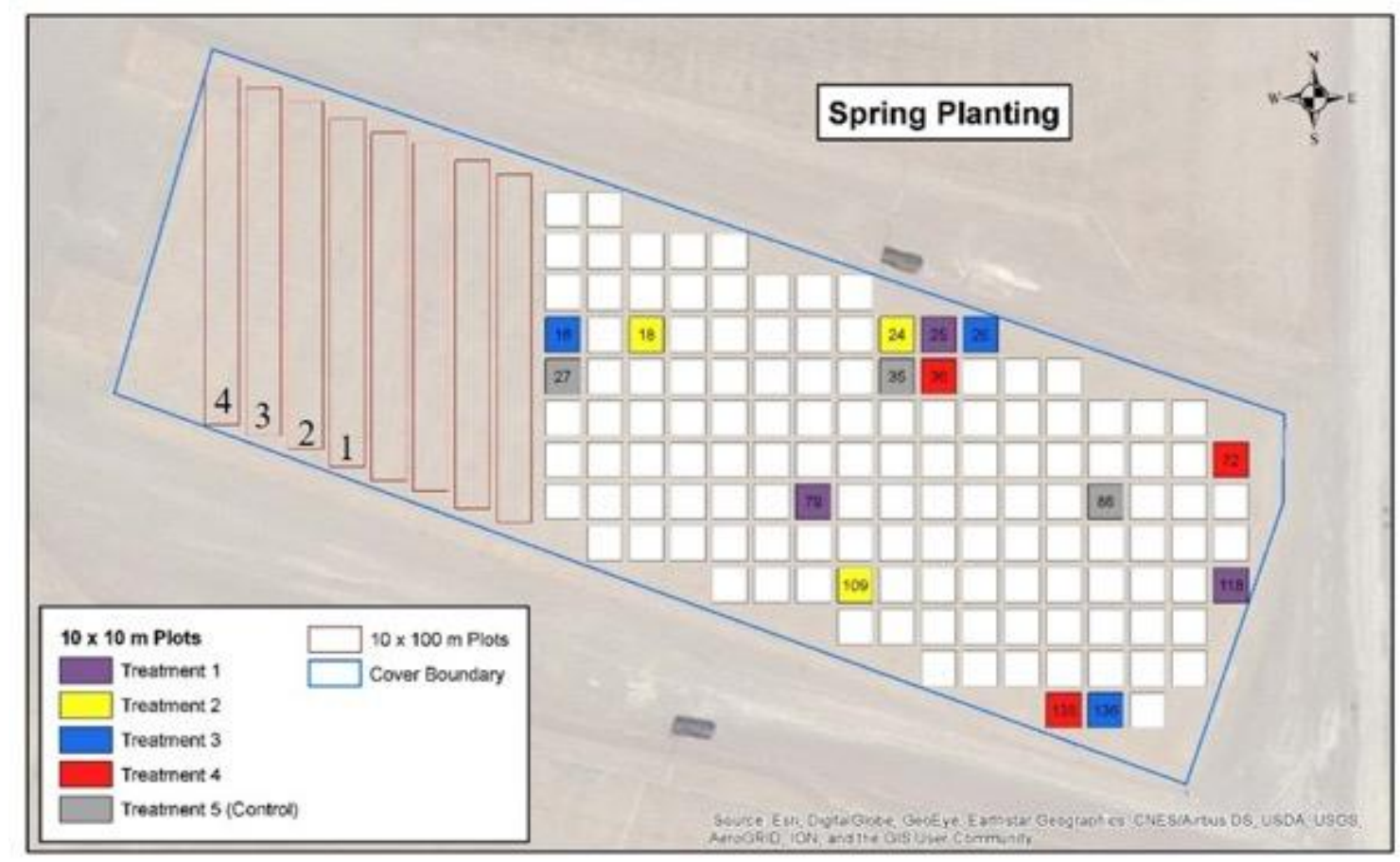

Figure 12. Plot design and location of plots planted in the spring. The north-south plots on the west side of the cover are the transplant plots.

The western portion of the cover was selected for the transplant only study, where eight $10 \mathrm{~m} \times 100 \mathrm{~m}(32.8 \mathrm{ft} \times 328 \mathrm{ft})$ plots were established. Four plots were planted in fall/winter (Figure 10) and four were planted in the spring of FY18. Four plots total (two from each planting event) were watered twice per week with approximately 7.5 liters ( 2 gallons) per watering event using drip emitters for the first five months after planting. After five months, watering was reduced to once per week for all plots for 20 minutes. Watering was not performed during the week if rainfall amounts equaled or exceeded $0.5 \mathrm{~cm}$ $\left(0.2\right.$ in) or air temperature was equal or below $35^{\circ} \mathrm{F}\left(1.7^{\circ} \mathrm{C}\right)$ during that week. In FY20, watering was systematically reduced for all plots according to a schedule recommended by the TRC members to allow plants to gently adapt to natural precipitation cycles. Starting in January 2020, watering was adjusted to occur approximately every 10 days during January/February (roughly three watering events per month), then approximately every 15 days during March/April (roughly two watering events per month), then approximately every 20 days during May/June (roughly one watering event per month), then approximately every 25 days during July/August (also roughly one watering event per month, but more widely spaced than the May/June watering), with the cessation of watering occurring in September 2020. Table S-4 summarizes the total amount of water applied per plot per year, including both irrigation and natural precipitation.

Seeds used in the planting $(10 \mathrm{~m} \times 10 \mathrm{~m}[32.8 \mathrm{ft} \times 32.8 \mathrm{ft}]$ plots $)$ were the same as those proposed in the Fieldwork Plan (Spoon and Barcalow, 2017) (Table 3), with the exception of desert trumpet (Eriogonum inflatum) for which seeds could not be found. The TRC members emphasized the importance of selecting diverse species that are appropriate for the habitats to replicate the natural environment surrounding the 92-Acre Area. In the 
Table 3. List of species used in the seed mix and amount of seed $(10 \mathrm{~m} \times 10 \mathrm{~m}$ $[32.8 \mathrm{ft} \times 32.8 \mathrm{ft}]$ plots).

\begin{tabular}{lccc}
\hline Form & Common Name & Scientific Name & $\begin{array}{c}\text { Seed Rate (kg of } \\
\text { pure live seed/ha) }\end{array}$ \\
\hline Forb & Desert marigold & Baileya multiradiata & 1 \\
Forb & Desert globemallow & Sphaeralcea ambigua & 1 \\
Grass & Indian rice grass & Achnatherum hymenoides & 2 \\
Grass & Squirreltail & Elymus elymoides & 1 \\
Shrub & Creosote bush & Larrea tridentata & 4 \\
Shrub & Four-wing saltbush & Atriplex canescens & 4.5 \\
Shrub & Desert thorn & Lycium andersonii & 3 \\
Shrub & Indian tea & Ephedra nevadensis & 3 \\
Shrub & Shadscale & Atriplex confertifolia & 3 \\
\hline
\end{tabular}

words of a TRC member at a planning meeting to create the research design: "I think $a$ variety of plants should be planted near one another, so life continues throughout the seasons and keeps the land active." The TRC members also recommended a combination of seeds and outplants. The outplants were considered to provide shade and critical nutrients to the seeds. According to a TRC member, "... shade is important for that area. We should transplant along with seeds. That shade is necessary to help seedlings grow."

In FY18, the TRC members prepared and observed seeds that would be spread incrementally by the planting subcontractor (Soil-Tech, Inc.) by separating the appropriate amount of seed for each plot from an appropriate shipping bag. This activity was described as a critical component in the spiritual management of the land. It also served as an opportunity for the TRC members to make relationships with the plants. A TRC member explained, "I still think about the time we were with the seeds, we could at least touch the seeds, and that little bluebird came down. It was special for us to see. It was a representation of hope and thankfulness."

A total of three species of plants were transplanted (Table 4) rather than the five proposed species because of unavailability. The plants transplanted into the seeded plots $(10 \mathrm{~m} \times 10 \mathrm{~m}[32.8 \mathrm{ft} \times 32.8 \mathrm{ft}])$ were caged to reduce herbivory. However, rather than caging individual plants in the transplant plots $(10 \mathrm{~m} \times 100 \mathrm{~m}[32.8 \mathrm{ft} \times 328 \mathrm{ft}])$, the entire group of eight plots were fenced with a wire-mesh fence. The TRC members considered caging an important protective step at the onset of revegetation to help reduce predation from various animals and insects. In the words of a Numic spiritual leader, "... restrict animals in the beginning when the plants are starting to grow because they may dig or track over the seedlings." The TRC advised that the cages should be removed at a time recommended by the group as the plants develop. A TRC member explained that as the plant matures, "The animals can help with spreading seeds and nurturing the plant." A Numic spiritual leader added, "...plants need to be 'trimmed' by animals. They eat the insects and disturb the land and make the land self-cultivating. If bigger animals eat plants, they are fertilizer. They are also good for transferring seeds from different areas." 
Table 4. List of plants used for outplants in both the seeded plots and the transplant plots.

\begin{tabular}{lcc}
\hline Form & Common Name & Scientific Name \\
\hline Forb & Desert globemallow & Sphaeralcea ambigua \\
Shrub & Creosote bush & Larrea tridentata \\
Shrub & Four-wing saltbush & Atriplex canescens \\
\hline
\end{tabular}

The TRC members considered their inability to directly plant the seeds and outplants to be a significant challenge in establishing relationships with the land. The techniques suggested in the original Fieldwork Plan were therefore modified to adapt to the various restrictions at the site (Spoon and Barcalow, 2017). For a reference point, here is a description of traditional planting techniques without restrictions from a TRC member: "... we did not plant in rows. We dug a little pit about three feet across in diameter and four inches deep, the seeds were planted, and earth was put over. When it rained, water collected in the pit, water was also brought from nearby springs, if available. The planting season was typically in the spring."

New knowledge was developed to meet this challenge through blended TEK and Western science to accommodate project circumstances of working on a secured site with low-level radioactive waste beneath it. Although using traditional digging sticks to simulate traditional planting was preferred, the approach was modified to use the top end of a shovel handle to replicate the TEK approach. Tables 5 and 6 list the variables used for the $10 \mathrm{~m} \times 10 \mathrm{~m}(32.8 \mathrm{ft} \times 32.8 \mathrm{ft})$ and $10 \mathrm{~m} \times 100 \mathrm{~m}(32.8 \mathrm{ft} \times 328 \mathrm{ft})$ plots $($ Spoon and Barcalow, 2017). Changes are noted where TEK was adapted to fit regulations at the 92-Acre Area. 
Table 5. Variable selection and corresponding Numic ecological knowledge and adaptation for Tribal Revegetation Project (seeded and outplant treatments).

\begin{tabular}{lll}
\hline Variable & Characteristics & $\begin{array}{l}\text { Numic Ecological Knowledge and Adaptation for Tribal } \\
\text { Revegetation Project }\end{array}$ \\
\hline Planting & Direct seed and broadcast & Use digging sticks is customary to seed directly into the soil using a \\
Technique & native seed mix sourced locally. As an alternative that is scalable to \\
& the 92-Acre Area, a seed drill could be used to mimic the use of \\
digging sticks with unknown results. On-site seed collection may not \\
be possible because of the number of seeds required. The project will \\
rely on broadcast seeding as an alternative for comparative purposes. \\
\end{tabular}

Table 6. Variable selection and corresponding Numic ecological knowledge and adaptation for Tribal Revegetation Project (outplant-only treatments).

\begin{tabular}{|c|c|c|}
\hline Variable & Characteristics & $\begin{array}{l}\text { Numic Ecological Knowledge and Adaptation for Tribal } \\
\text { Revegetation Project }\end{array}$ \\
\hline Topsoil & $\begin{array}{l}\text { Soil enhancement using } \\
\text { on-site topsoil }\end{array}$ & $\begin{array}{l}\text { Nutrient-rich topsoil or supplemental existing soils is highly } \\
\text { recommended. Borrow pits should be avoided. This process may } \\
\text { include burning nutrient-rich plants in areas outside the RWMC in } \\
\text { designated areas, then mulching the contents into the soil. It is } \\
\text { understood that burning non-native plants in the entire } 92 \text {-Acre } \\
\text { Area is not currently an option on the NNSS. Only use on-site } \\
\text { topsoil when it is part of another ground disturbance activity from } \\
\text { another comparable ecological setting. To adapt to site conditions } \\
\text { and security protocol, new topsoil can be rotated into other } \\
\text { revegetation projects from the construction of new waste cells or } \\
\text { ground disturbance in adjoining areas. }\end{array}$ \\
\hline Irrigation & Drip irrigation & $\begin{array}{l}\text { Every plant requires an appropriate amount of water to be } \\
\text { sustained and no more. Extreme overwatering causes harmful } \\
\text { effects to the environment, and therefore upsets the balance of the } \\
\text { land. Drip irrigation helps young, volatile plants thrive in difficult } \\
\text { conditions because it provides water directly to the plants. } \\
\text { Sprinklers, although more cost effective, can provide a significant } \\
\text { amount of water loss and evaporation, which supports the } \\
\text { recommendation for drip-irrigation-based watering, based on a } \\
\text { long-term monthly average precipitation data from the nearby } \\
\text { Well 5b/M5 precipitation gage. }\end{array}$ \\
\hline
\end{tabular}




\section{Field Observation (Monitoring)}

Field observation was considered vital for both spiritual management and collecting data for the revegetation study. The TRC members interacted with the plants in the test plots and the broader 92-Acre Area while monitoring resources by building and sustaining interactive relationships. This includes reinforcing prayers left on the land at the onset and throughout the life of the project. Although left on the ground, prayers can become less effective if not nurtured. According to a TRC member, "...we need to keep monitoring, and not just let the plants die. It's not just a job for us. The plants need to be monitored. Personally, we are there for a reason and a purpose."

To efficiently measure and tally the number of plants on the seeded plots $(10 \mathrm{~m} \times 10 \mathrm{~m}[32.8 \mathrm{ft} \times 32.8 \mathrm{ft}])$, a $1 \mathrm{~m} \times 1 \mathrm{~m}(3.3 \mathrm{ft} \times 3.3 \mathrm{ft})$ quadrat was randomly placed within the plot (Figure 13). All plants within the quadrat were identified by species and tallied with an average height of growth measured for each species type. Because the $1 \mathrm{~m} \times 1 \mathrm{~m}(3.3 \mathrm{ft} \times 3.3 \mathrm{ft})$ quadrat only measured one percent of the plot, TRC members surveyed the remainder of the plot and recorded (qualitatively) all species of native plants present. On plots with outplants, TRC members recorded the condition of each plant as alive, dead, or dormant. The height was measured for each individual plant and notes were taken specifying flowering, produced seeds, or any observed damage and/or evidence of animal or insect activity. The TRC members consider the continuation of field observation to be central to the future success of the revegetation efforts at the 92-Acre Area. A TRC member commented, "I think it's very important that we continue to go out and monitor and, you know, say our prayers and our blessings to encourage the plants to keep on growing."

Plants were classified as dead if they had dry, brittle stems and the leaves were not photosynthesizing (i.e., the leaves were not green). In some cases, mortality was difficult to determine because of the propensity for desert plants to become dormant during hot or dry periods and appear unhealthy. Additionally, many plants will resprout from the roots if the crown dies. Therefore, the percentage of survival may change as some plants that appear dead are later discovered to be alive, thereby modifying the number of positive results and corresponding data variations throughout subsequent growing seasons. The TRC members emphasized that the underground root systems of dormant plants are critical for healthy ecosystem functions, even if the aboveground plant appears to be stressed or dead. 


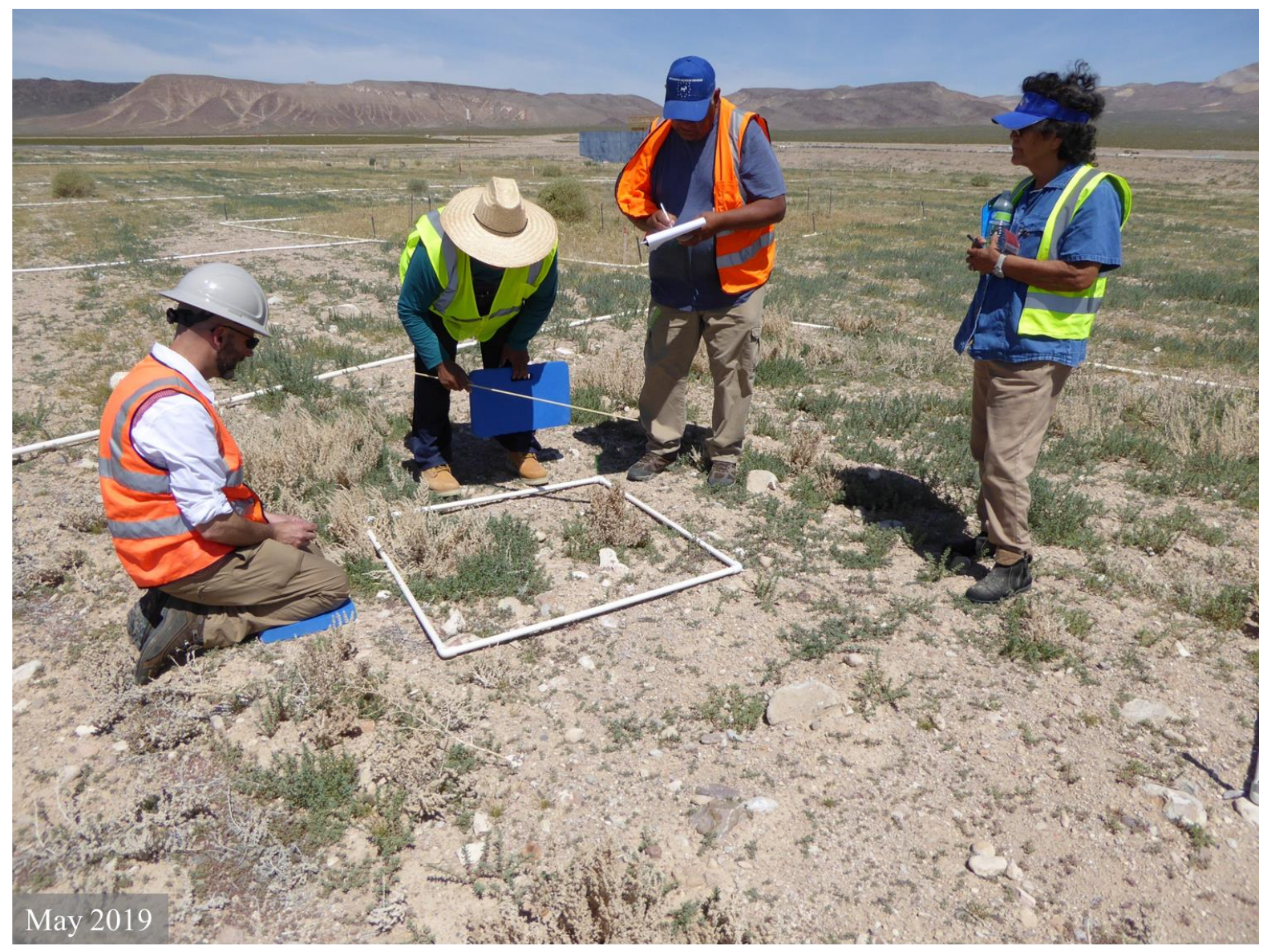

Figure 13. Members of the TRC and a representative from PSU counting plants within the randomly placed $1 \mathrm{~m} \times 1 \mathrm{~m}(3.3 \mathrm{ft} \times 3.3 \mathrm{ft})$ quadrat within a $10 \mathrm{~m} \times 10 \mathrm{~m}(32.8 \mathrm{ft} \times 32.8 \mathrm{ft})$ plot.

\section{RESULTS AND INTERPRETATION}

\section{Outplant Survival}

Outplants are plants grown in a greenhouse or nursery and they are sometimes referred to as "transplants" in earlier project documents and plot treatment descriptions. When it became clear that actual transplants (plants grown in the desert and relocated from nearby areas) would not be available for planting in this project as planned, outplants were sourced from regional greenhouse growers. Outplants were planted in select $10 \mathrm{~m} \times 10 \mathrm{~m}$ $(32.8 \mathrm{ft} \times 32.8 \mathrm{ft})$ plots along with seed distribution at a density of 0.06 plants $/ \mathrm{m}^{2}$, and the $10 \mathrm{~m} \times 100 \mathrm{~m}(32.8 \mathrm{ft} \times 328 \mathrm{ft})$ plots consisted solely of outplants (as described in the "Revegetation Study Field Methods" section above) planted at a density of $\sim 0.03$ plants $/ \mathrm{m}^{2}$ ). As discussed, the TRC members preferred to source local transplants and seeds, but this was not possible because of DOE regulations, timing, and logistics. 
In the $10 \mathrm{~m} \times 10 \mathrm{~m}(32.8 \mathrm{ft} \times 32.8 \mathrm{ft})$ plots, outplants were added to plots with the following treatments: transplant + soil amendment + straw addition $(\mathrm{T}+\mathrm{S}+\mathrm{St})$ or transplant + mulch addition $(\mathrm{T}+\mathrm{M})$. When comparing outplant performance within these plots, those planted in the spring generally outperformed those planted in the fall/winter in all years for each plant species and treatment type (Figures 14a to 14c). In FY20, plots planted in the spring ranged from 67 percent to 100 percent average survival and plots planted in the fall ranged from 17 percent to 100 percent average survival. This difference in average percent survival is significant ( $\mathrm{p}=4.1 \times 10^{-7}$, two-tailed t-test with unequal variance) and suggests that planting outplants in the spring may produce more reliably high average percent survival across species types.
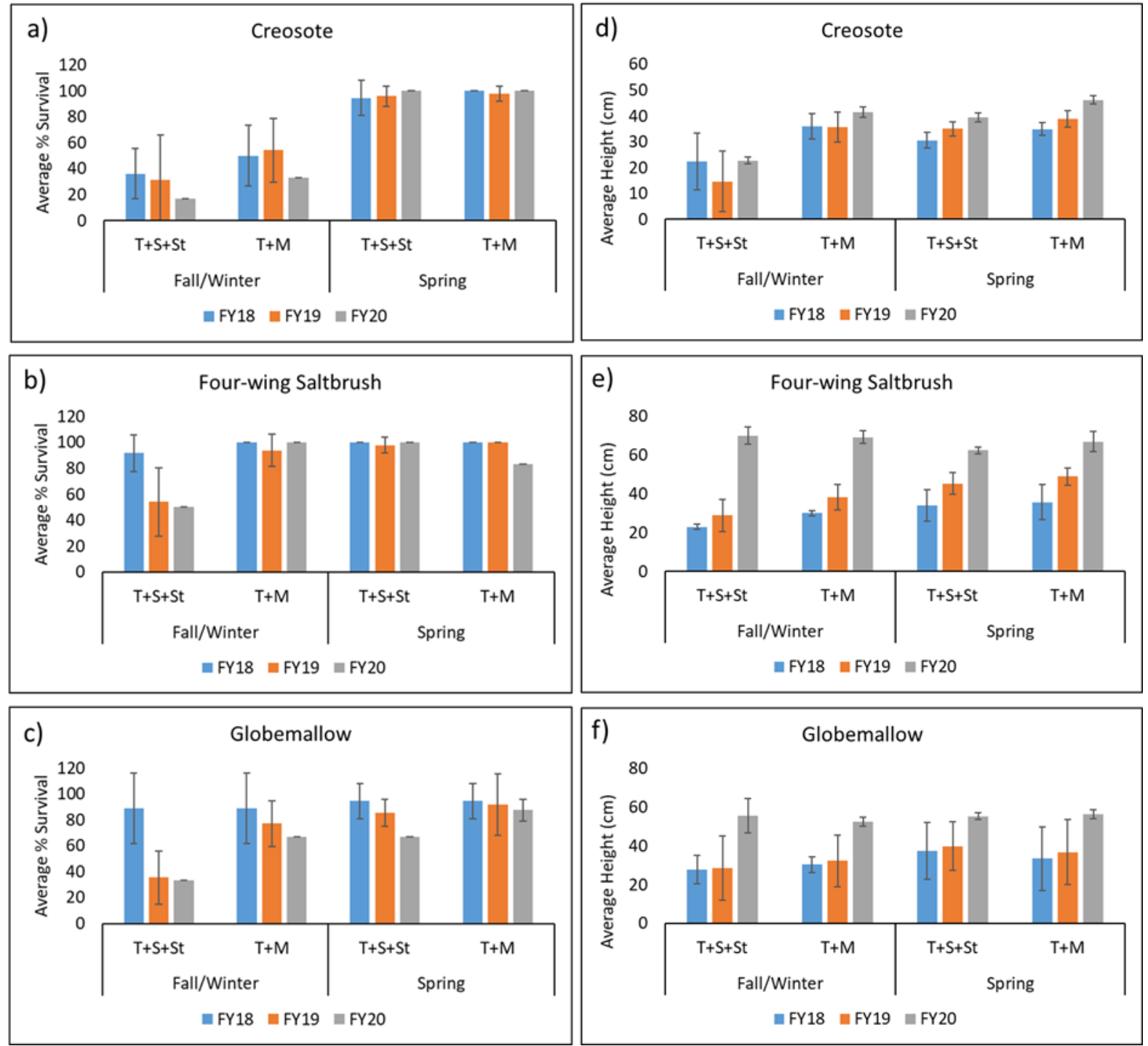

Figure 14. Average percent survival (a-c) and average height (in $\mathrm{cm}$ ) of surviving plants (d-f) across the growing season for outplants within $10 \mathrm{~m} \times 10 \mathrm{~m}(32.8 \mathrm{ft} \times 32.8 \mathrm{ft})$ plots for all three fiscal years of monitoring. Error bars represent standard deviation of the average across each growing season. Treatment: $\mathrm{T}+\mathrm{S}+\mathrm{St}=$ transplant + soil amendment + straw addition, whereas $\mathrm{T}+\mathrm{M}=$ transplant + mulch addition. 
From the onset of the project, the TRC members predicted that the spring season was the appropriate time to plant on such disturbed land for both outplants and seeded species. They advised that planting in the winter strains the plants, similar to not nurturing a person in the cold. It is considered unhealthy. The winter is therefore a time when the plants energy is sustained in the roots. According to a TRC member, "...you work with the plants in the winter. Everything is dropped into roots. The plant is only getting half of its potential during that season. In spring, everything begins climbing. The stems, roots. Everything is at its full potential getting full strength."

This TRC knowledge is further supported by published studies suggesting several potential physiological mechanisms contributing to the enhanced survival of spring-planted plants. Spring planting and subsequent regular irrigation throughout the warm summer season (as used in this revegetation effort) may promote the development of beneficial soil fungi that form symbiotic mycorrhizal relationships with plant roots and enhance the nutrient uptake of plants, whereas the cool weather encountered after a fall planting may result in slower fungal development (Barrow et al., 1997; Titus et al., 2002). Spring planting also reduces the potential for significant cold shock after planting, which can negatively affect outplant survival in warm, arid environments (Fidelibus and MacAller, 1995).

When considering the two treatment types, slightly higher average percent survival rates were often observed in $\mathrm{T}+\mathrm{M}$ treatments than $\mathrm{T}+\mathrm{S}+\mathrm{St}$ treatments, which is a difference that is significant when both planting seasons are considered $(\mathrm{p}=0.04$, two-tailed t-test with unequal variance). In FY20, the survival rates of all species ranging from 67 percent to 100 percent in $\mathrm{T}+\mathrm{S}+\mathrm{St}$ spring plots and from 83 percent to 100 percent in $\mathrm{T}+\mathrm{M}$ spring plots (Figures 14a to 14c and Table S-1a in the "Supplementary Materials" section). The average height of the surviving outplants in the $10 \mathrm{~m} \times 10 \mathrm{~m}(32.8 \mathrm{ft} \times 32.8 \mathrm{ft})$ plots increased over the course of the study, with each plant species in all plot treatments achieving the greatest average height in FY20, which was the final year of monitoring (Figures 14d to 14e). This is likely an indication that surviving plants are well-established and not experiencing significant water or nutrient stress, even though irrigation was systematically reduced and ultimately eliminated in FY20. The TRC members view this finding as the outplants stabilizing their relationships with the land and one another by reaching their greatest height in their third year of growth despite changes in the irrigation schedule. The TRC members also consider the success of these outplants in their adaptation to reduced water as a cultural indicator that the plants are healthy and established. The TRC members explained that once the larger outplants are established, they help the seedlings with shade and other nutrients. Indeed, studies confirm that soil moisture in desert habitats is positively correlated with the presence of shrub vegetation because the shade created by the plant biomass promotes soil moisture retention (Pan and Wang, 2009), the presence of shrubs has an overall net positive effect on the development of nearby annual plants in the Mojave Desert (Holzapfel and Mahall, 1999), and seed density within desert soil is likely to be significantly higher under plant canopies than in interspace soils (Zhao et al., 2007).

In $10 \mathrm{~m} \times 100 \mathrm{~m}(32.8 \mathrm{ft} \times 328 \mathrm{ft})$ plots, watering was generally the most impactful variable on outplant survival, with a significantly greater average percent survival in watered plots ( 77 percent) than in unwatered plots ( 51 percent; $\mathrm{p}=0.0001$, two-tailed t-test with unequal variance) in FY20. Plots that received water consistently showed higher average 

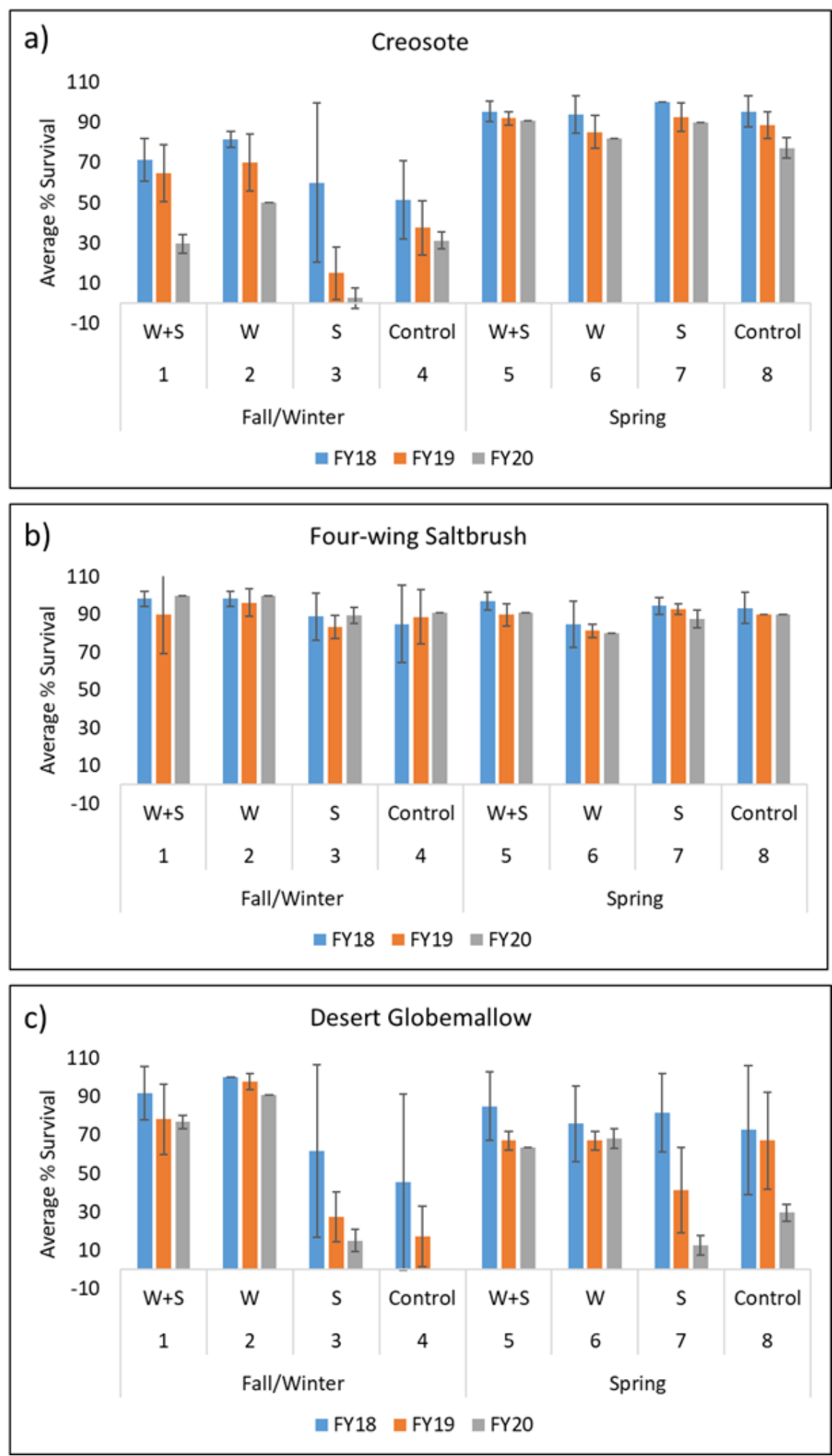

Figure 15. Average percent survival and standard deviation (error bars) across the growing season for outplants within $10 \mathrm{~m} \times 100 \mathrm{~m}(32.8 \mathrm{ft} \times 328 \mathrm{ft})$ plots, for all three fiscal years of monitoring. Treatment: $\mathrm{W}+\mathrm{S}=$ water + soil amendment, $\mathrm{W}=$ water only, $\mathrm{S}=$ soil amendment only, and Control $=$ no additions. 
percent survival of outplants compared with plots that did not receive water within the same planting season (Figure 15). Among the watered plots, outplant survival rates were similar between those that did $(\mathrm{W}+\mathrm{S})$ and $\operatorname{did}$ not $(\mathrm{W})$ receive soil amendment prior to planting (Figure 15), with the notable exception of four-wing saltbrush, for which average percent survival was high for all treatment types in all years (Figure 15b). The TRC members indicated that the outplants of the four-wing saltbrush and legacy plants that grew significantly during the three-year revegetation study are keystone species for this ecosystem. Once established, these plants can thrive in the saline soils and help other seeded species and outplants develop, which is knowledge that is supported by published literature (Holzapfel and Mahall, 1999; Zhao et al., 2007; Pan and Wang, 2009).

The TRC members considered the four-wing saltbrush to be a hearty species that is adapted for the disturbed soils at the 92-Acre Area. They pointed out that the future species composition at the 92-Acre Area will most likely be different from the surrounding environment because of the salinity of the soils and unknown constituents in the no-growth zone. The four-wing saltbrush is therefore a forerunner that can assist other more sensitive species, such as creosote, in adapting to this area. A TRC member commented, "Four-wing will be out there since it's strong plant. Maybe it is the saltiness of the soil. If look across the road, not a lot of four-wing, it is all creosote. So, it is the soil. But if we had soil like across the road, the creosote can have a greater possibility of surviving." The TRC members also pointed out that there were four-wing saltbrush and legacy plants that were thriving without water. This was considered an indicator of success. A TRC member commented, "I was pretty impressed with the four-wing saltbrush in being tall and strong. The four-wing along fence line not being watered but still growing." Another TRC member speaks about the state of the four-wing saltbrush from the plant's perspective:

If I was one of those big four-wing saltbush, I'd be pretty happy and in bloom and then when things were over with, I'd go dormant and be pretty proud... and I could help these guys [other plants] being older and bigger to talk to the younger ones and tell them to hang on, your time's coming too, you'll get big like me and we will thrive.

A TRC member added that the four-wing would say, "I'm thankful these people are coming around to help us reclaim our area, reclaim our lands. And that we can grow, and we are strong once we are understood and people take the time to appreciate our value."

This knowledge is supported by extensive primary literature describing the resiliency of four-wing saltbrush in arid environments (Glenn et al., 1998), the many physiological adaptations that allow this species to thrive in high-salt and low-moisture conditions (Barrow et al., 1997; Hao et al. 2013; Guo et al., 2020), and its subsequent role as a regional keystone species that can facilitate the emergence of additional plant species and provide sustenance to herbivorous animals (Holzapfel and Mahall, 1999; Zhao et al., 2007; Pan and Wang, 2009; Benzarti et al., 2013).

For outplant species other than four-wing saltbrush, some planting season influence was observed. Among watered plots in FY20, creosote showed significantly higher $\left(\mathrm{p}=2.05 \times 10^{-6}\right.$, two-tailed t-test with unequal variance) average percent survival in springplanted plots ( 82 percent to 91 percent survival in spring-planted watered plots versus 30 percent to 50 percent survival in fall-planted watered plots after three years; Figure 15a, 
Table S-2a), whereas globemallow showed slightly lower (but still high overall) percent survival in spring-planted plots (64 percent to 68 percent survival in spring-planted watered plots versus 77 percent to 91 percent survival in fall-planted watered plots after three years; Figure 15c, Table S-2a). The TRC members view creosote as a species that requires special care to thrive in disturbed soils, especially because it represents strong Indigenous medicine, and space to grow because it emits toxins so that other plants do not outcompete for nutrients or stunt plant growth. According to a TRC member, “... besides Creosote being one of our native medicines, maybe it will take more time to grow because it is getting its medicine from the ground." Even so, the three-year survival rates observed for both creosote and globemallow outplants in this revegetation effort, which centered TEK and incorporated spiritual land management, are much greater than the survival reported for creosote and globemallow outplants in another Mojave Desert study, which showed 23 percent and 55 percent survival, respectively, after three years (Abella et al., 2012). Abella et al. (2012) also used different irrigation rates than this study. Abella et al. (2012) applied $1 \mathrm{~L}$ of water immediately after outplant planting, and thereafter used slow-release DriWater gel packs that were recharged after $3,5,7,15$, and 20 months (the actual water volumes applied via this method were not disclosed).

The surviving outplants in the $10 \mathrm{~m} \times 100 \mathrm{~m}(32.8 \mathrm{ft} \times 328 \mathrm{ft})$ plots showed an increasing average plant height over time in all watered treatments and a generally increasing plant height in non-watered plots, with some exceptions (Figure 16). This also suggests that surviving plants are well established and continue to dedicate energy to aboveground biomass production. The TRC members considered the biomass both above and below the soil to be an important cultural indicator used in the restoration of environmental health. The TRC members specifically identified that dormant desert globemallow has critical biomass underground that communicates with the land through the root system.

Combined, the plant survival rates and observed heights in the $10 \mathrm{~m} \times 100 \mathrm{~m}$ $(32.8 \mathrm{ft} \times 328 \mathrm{ft})$ plots suggest that outplant survival depends foremost on irrigation after planting, and that planting during spring with the addition of irrigation may produce reliably high average percent survival for all three outplant species studied here. This is consistent with observations from the $10 \mathrm{~m} \times 10 \mathrm{~m}(32.8 \mathrm{ft} \times 32.8 \mathrm{ft})$ plots in which spring planting produced a more reliably high percent survival for the three outplant species in watered plots. From a Numic perspective, the success in outplant survival is attributed to the land reuniting with its relatives and welcoming new plants. The TRC stated, "The reason we are getting the response is the land recognizes us. When something is broken, we need to fix it, or it gets worse. When the land is sick, we are sick." 

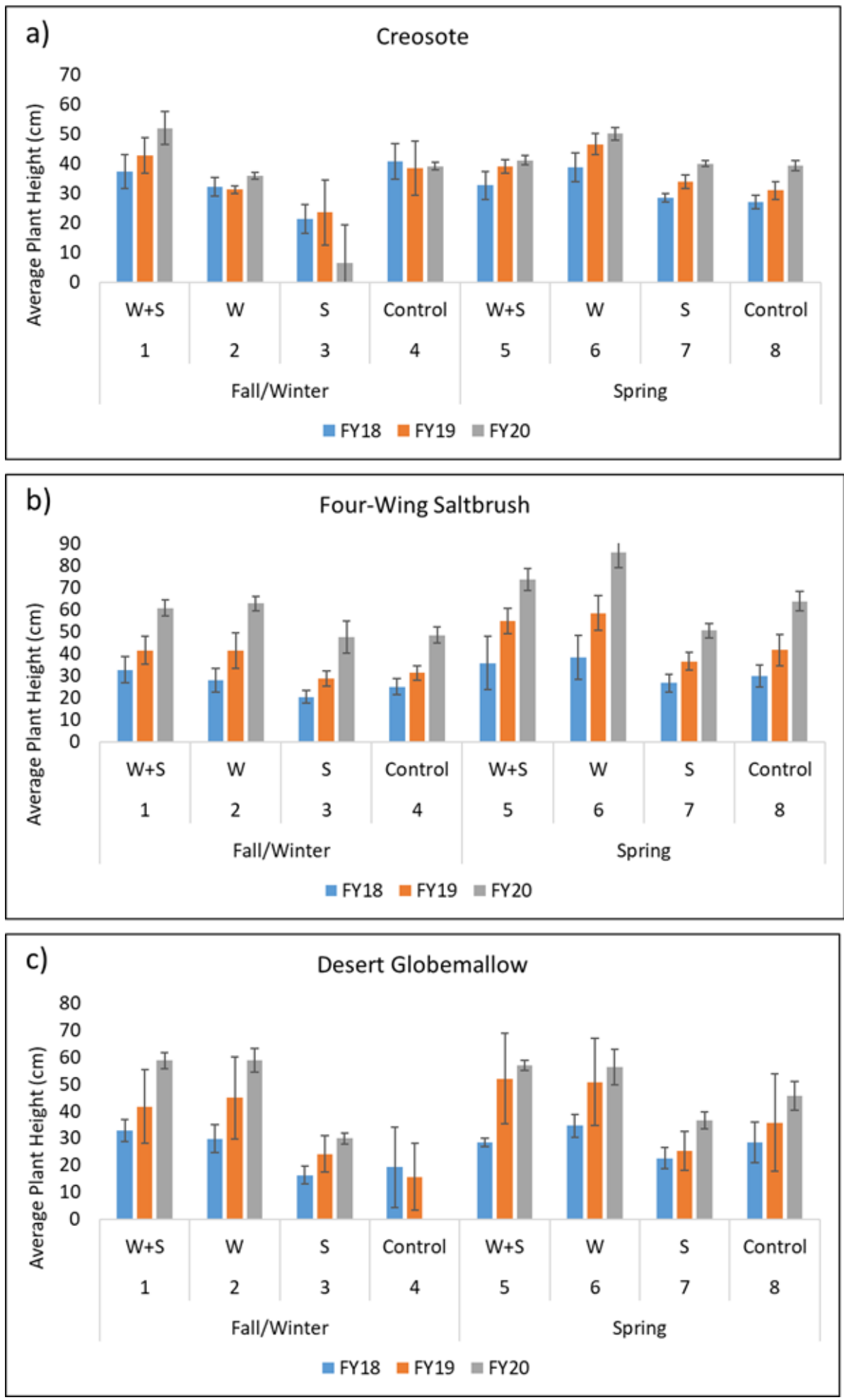

Figure 16. Average height of surviving outplants and standard deviation (error bars) across the growing season for outplants within $10 \mathrm{~m} \times 100 \mathrm{~m}(32.8 \mathrm{ft} \times 328 \mathrm{ft})$ plots, for all three fiscal years of monitoring. Treatment: $\mathrm{W}+\mathrm{S}=$ water + soil amendment, $\mathrm{W}=$ water only, $\mathrm{S}=$ soil amendment only, and Control = no additions. 


\section{Native Plants from Seed}

All $10 \mathrm{~m} \times 10 \mathrm{~m}(32.8 \mathrm{ft} \times 32.8 \mathrm{ft})$ plots received native plant seed mix as described in the "Revegetation Study Field Methods" section of this report. When considering the native plants emerging from seed in these plots, clear performance differences are noted between plots with different pretreatments.

Figure 17 shows the average overall native plant densities per square meter in the $10 \mathrm{~m} \times 10 \mathrm{~m}(32.8 \mathrm{ft} \times 32.8 \mathrm{ft})$ plots. Plots with treatment $\mathrm{S}+\mathrm{M}$ (soil amendment + mulch) had consistently high average native plant density in all fiscal years (Figure 17a) compared with all other plot treatments. Additionally, within S+M treatment plots, average plant density was higher in spring-planted plots than in fall/winter-planted plots in all years (Figure 17a). This trend persisted throughout the study and was still significant in FY20, the final year of monitoring, in which spring-planted $\mathrm{S}+\mathrm{M}$ plots showed significantly higher average native plant density than other treatments across planting seasons (one-way ANOVA $[\mathrm{F}(9,30)=2.55, \mathrm{p}=0.026])$. The TRC members considered mulch to be a critical attribute for providing nutrients to barren or unhealthy soil. A TRC member added, ".... a mulch of natural plant resources should be surrounding the plant to ensure growth and saturation of an irrigated land, not sprinkled." Although in some instances the use of mulch in other desert revegetation efforts has yielded insignificant influence on outplant or transplant survival (Bainbridge et al., 2001; Scoles-Sciulla et al., 2015), the combination of mulch with a soil amendment and cultural intervention in this study, as suggested by the TRC members, clearly produced the highest native plant survival from seed. The establishment of Mojave Desert plants from seed is known to be difficult in revegetation scenarios (Clary and Slayback, 1983; Abella et al., 2012) and this S+M soil treatment in conjunction with spiritual land management by the TRC members should be considered a promising method for promoting seedling establishment.

In all treatment types, significantly higher average plant density was observed in FY18, followed by substantially reduced average plant densities in subsequent years. The reduced density was not surprising and was predicted by the TRC members because it is common for many seeds to germinate immediately after planting only to self-thin as a result of competition for water, nutrients, and physical space, as well as variable tolerance to natural weather stressors and loss by herbivory (Bowers et al., 2004). However, among all treatment types, only spring-planted $\mathrm{S}+\mathrm{M}$ plots showed an increasing average native plant density between FY19 and FY20. There was significant rainfall during winter of 2019 and spring of 2020, which could have affected native plant growth (Table S-4). However, not all plots showed the increased native plant density from FY19 to FY20 as seen in the springplanted $\mathrm{S}+\mathrm{M}$ plots. This suggests either that increased rainfall is not the main driver of this result or that the spring-planted $\mathrm{S}+\mathrm{M}$ treatment creates conditions that capitalize on the increased water availability. Among the plots that received outplants in addition to seed (treatments $\mathrm{T}+\mathrm{S}+\mathrm{St}$ and $\mathrm{T}+\mathrm{M}$ ), the average plant density from seed was consistently higher in $\mathrm{T}+\mathrm{M}$ plots. Together, these results suggest that mulch can be an important soil amendment for the successful establishment of native plants from seed. 

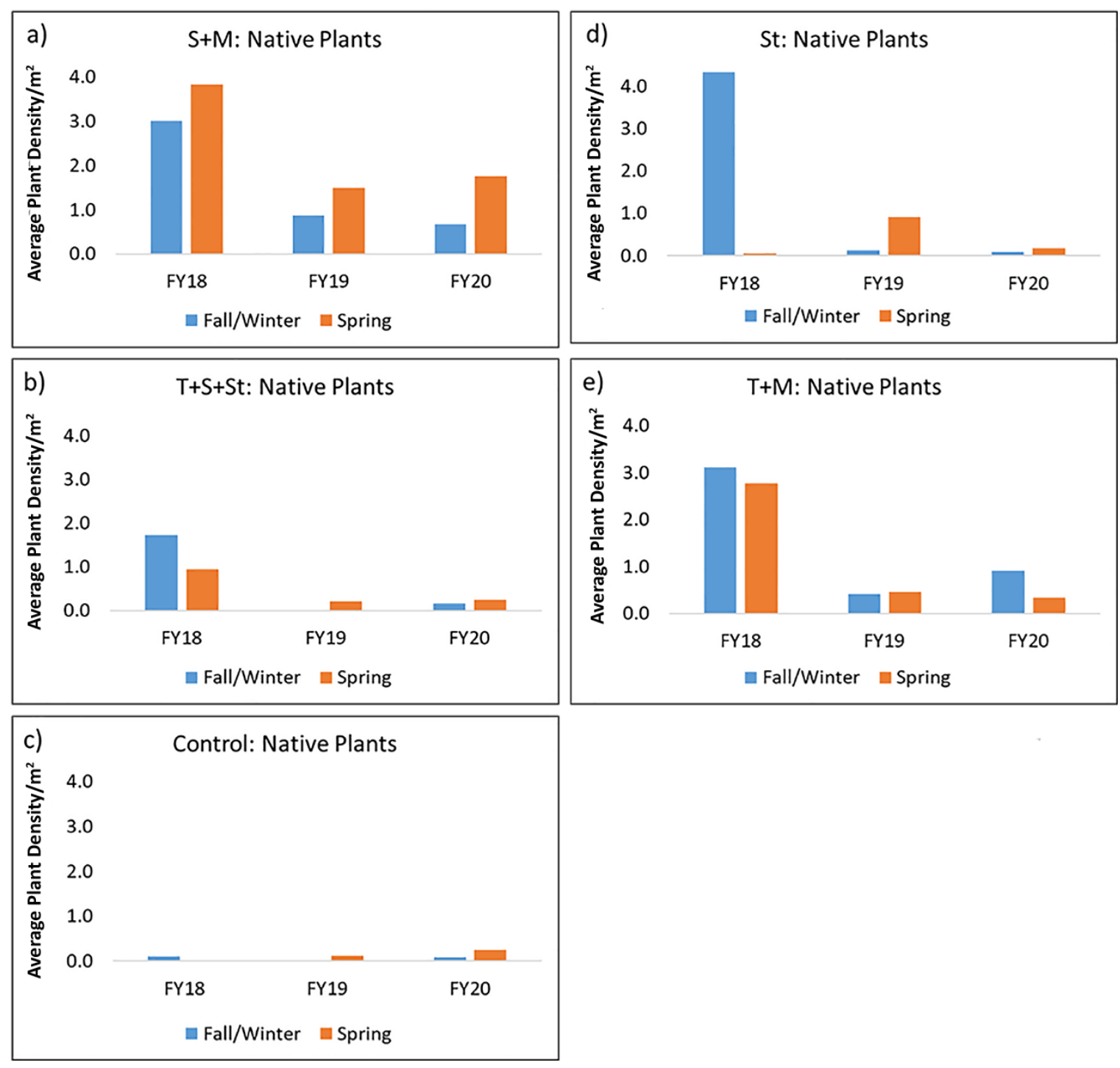

Figure 17. Average native plant densities (plants per square meter $\left[\mathrm{m}^{2}\right]$ ) in $10 \mathrm{~m} \times 10 \mathrm{~m}$ $(32.8 \mathrm{ft} \times 32.8 \mathrm{ft})$ plots for all years of monitoring. Treatment: (a) $\mathrm{S}+\mathrm{M}=$ soil amendment + mulch, (b) $\mathrm{T}+\mathrm{S}+\mathrm{St}=$ transplants + soil amendment + straw, (c) Control $=$ no additions, (d) $\mathrm{St}=$ straw only, and (e) $\mathrm{T}+\mathrm{M}=$ transplants + mulch.

Overall, the results suggest that adding a soil amendment plus mulch prior to spring planting is likely to produce the most favorable conditions for developing high native plant density from seed. These findings validate the prediction of a Numic spiritual leader who advised to "use topsoil from another area and natural fertilizer" because of the state of the soil at the 92-Acre Area. Indeed, the addition of soil amendments in various forms and regular irrigation prior to annual monsoonal rains have both been shown to positively affect native seedling emergence in the desert Southwest (Hall and Anderson, 1999; Roundy et al., 2001). 
Significant establishment of invasive plant species within the $10 \mathrm{~m} \times 10 \mathrm{~m}$ $(32.8 \mathrm{ft} \times 32.8 \mathrm{ft})$ plots was also observed. However, in all plot treatments except the control, a significantly lower average density of invasive species was seen in plots planted in the spring compared with those planted in fall/spring (Figure 18; $\mathrm{p}=0.02$, two-tailed t-test with unequal variance), which is additional evidence to support spring planting. The TRC members consider non-native species as tough "forerunners" to prepare the area for the native plants to thrive. The native species will eventually "overtake the non-native species since those are the ones that belong there." However, the non-native species have value and are considered living things that require relationships to be healthy. According to the TRC members, "...the invasive ones... are the first arrivals. They are preparing the native plants' way. If everything is totally barren and nothing is growing, obviously we know that something is wrong with the ground."

Indeed, the TRC believes the non-native species should not be considered invaders. A TRC member explained non-native plants are "actually needed...to lay it out, lay out the land first and then because it's showing that the land isn't completely ugly...only the toughest can survive sometimes in certain places... usually the tough ones always have to stand up first to make way for the other ones to come in."

The establishment of non-native plants in desert environments is traditionally considered to have a negative net effect on ecosystem health (Eckert and Kinsinger, 1960; Brooks, 2003; Duda et al., 2003), but this may not apply to constructed arid environments such as the raised cap at the 92-Acre Area, as suggested by the TRC members. This interpretation is supported by published studies that indicate the presence of "invasive" plant species may not negatively affect the resilience and long-term establishment of native plant species in heavily disturbed, arid environments. Annuals, and especially non-native annuals, in the Mojave Desert have been found to contain few indicators of arbuscular mycorrhizae development (beneficial associations of fungi with plant root structures that enhance plant growth by enabling increased nutrient uptake), whereas native plants studied from the NNSS, especially perennial shrubs and herbs, showed significant indicators of such mycorrhizae development (Titus et al., 2002). The enhanced procurement of vital nutrients facilitated by these arbuscular mycorrhizae gives perennial native plant species a long-term competitive edge over non-native annuals, especially in disturbed and low-nutrient environments, such as the 92-Acre Area.

Dense monoculture stands of Halogeton glomeratus (one of the most common invasive species recorded at the 92-Acre Area during this revegetation effort) have been shown to significantly raise soil sodium concentrations to potentially concerning levels (Eckert and Kinsinger, 1960; Duda et al., 2003). However, essential plant macronutrients (nitrogen, phosphorus, and potassium) were also found in higher concentrations in Halogeton-dominated soils compared with the adjacent native-plant dominated soils in western Utah (Duda et al., 2003). Therefore, some heterogeneous Halogeton colonization among native outplants and seedlings may enhance essential soil nutrients needed for native plant survival, especially in highly disturbed areas with low-nutrient soils, such as the 92-Acre Area. 

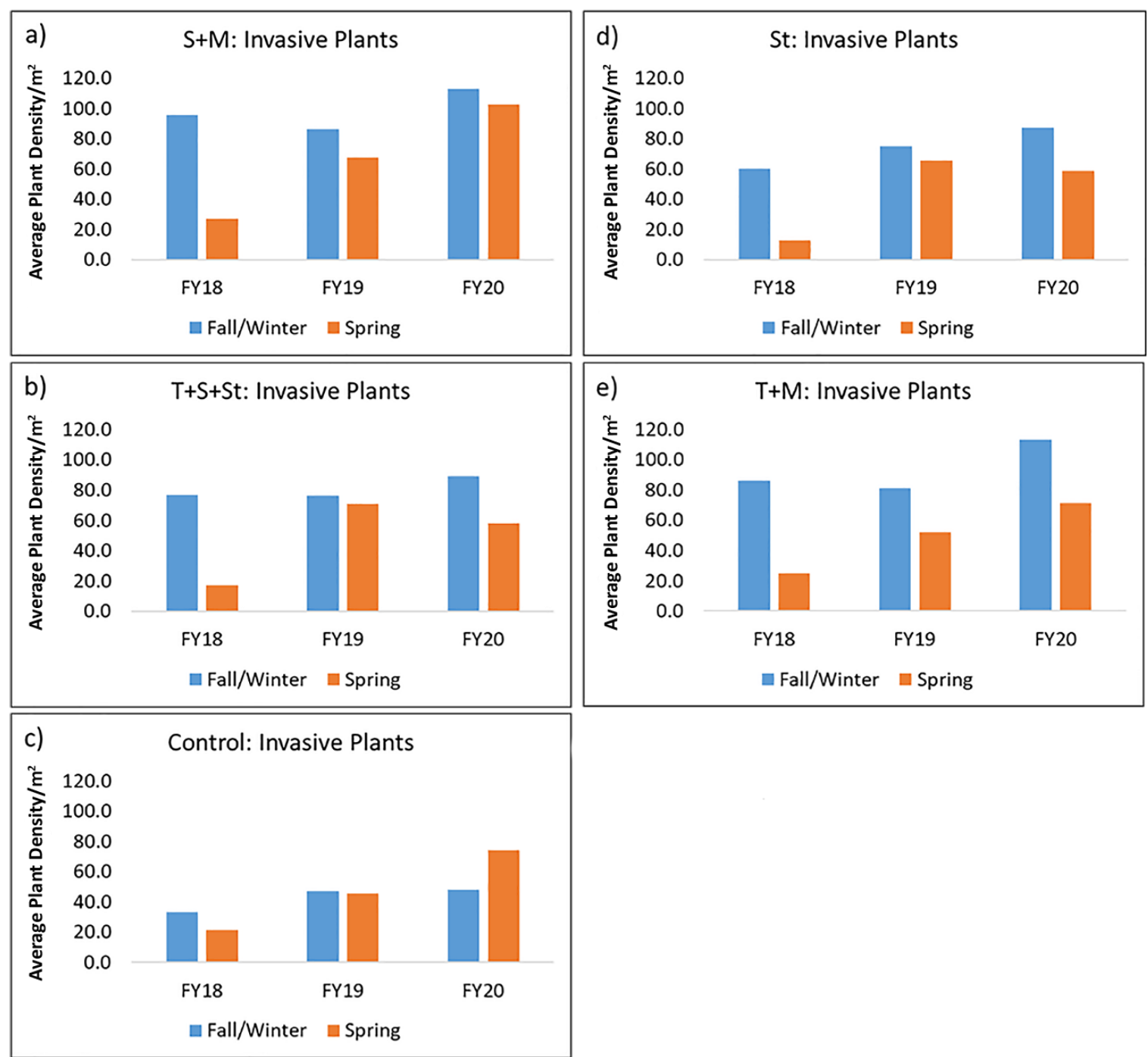

Figure 18. Average invasive plant densities (plants per square meter $\left[\mathrm{m}^{2}\right]$ ) in $10 \mathrm{~m} \times 10 \mathrm{~m}$ $(32.8 \mathrm{ft} \times 32.8 \mathrm{ft}$ ) plots for all years of monitoring. Treatment: (a) $\mathrm{S}+\mathrm{M}=$ soil amendment + mulch, (b) $\mathrm{T}+\mathrm{S}+\mathrm{St}=$ transplants + soil amendment + straw, (c) Control $=$ no additions, (d) $\mathrm{St}=$ straw only, and (e) $\mathrm{T}+\mathrm{M}=$ transplants + mulch.

Although competition from invasive species such as Halogeton glomeratus and Schismus sp. (the two most commonly observed non-native species at the 92-Acre Area) has been suggested to negatively affect native plant densities in desert environments (Brooks, 2000; Brooks, 2003), it has also been found that nutrient concentrations in the tissues of a native shrub species were not negatively affected by competition with Halogeton in western Utah, but that Halogeton fitness was negatively affected by competition with the native shrub. Native plants are also shown to reestablish after disturbance but at a slower rate, even though non-native plants are often the quickest initial plant colonizers after disturbance in arid locations (Kotanen, 1997). This highlights the need for progressive management strategies that foster native plant establishment in disturbed arid lands (Kotanen, 1997), such as the integration of TEK and associated spiritual management of the land by Indigenous participants. 
Therefore, at the 92-Acre Area, where the constructed and unnatural environment presents challenges for establishing any plant types, there may be beneficial interactions between quick-colonizing invasive species and native species to some extent. Furthermore, although competition for resources may affect the proliferation of native species, those native species have inherent adaptations to promote long-term establishment despite the presence of invasive species, and those adaptations can be fostered by systematic Tribal involvement and integrating TEK into land management practices.

In the final year of the project (FY20), a diverse set of native species had become established from seed across all $10 \mathrm{~m} \times 10 \mathrm{~m}(32.8 \mathrm{ft} \times 32.8 \mathrm{ft})$ plot types (Table 7$)$. Desert marigold from seed was especially abundant throughout the project, but only in treatments $\mathrm{T}+\mathrm{M}$ (outplants + mulch) and $\mathrm{S}+\mathrm{M}$ (soil amendments + mulch) after the initial emergence period of FY18.

The TRC members considered the abundance of desert marigold from seed in FY18 to be an early environmental indicator of the slow return of a healthy ecosystem, signaling that more native species could be anticipated in subsequent seasons. The TRC members emphasized that patience was needed to allow the native seeds to germinate at the appropriate time in this slow-growing ecosystem. At the end of the first field observation season, a TRC member commented, “... after monitoring for the year, I am very optimistic especially when we see the marigold popping up at the end of the year, and seeing the animals come back is a good thing." This TRC perspective is supported by another study, which found that of twelve plant species seeded in the Mojave Desert, desert marigold became established at one of the highest plant densities after two years of growth (Walker and Powell, 1999).

The trend of declining plant density after the initial FY18 germination is again common because seedlings begin to compete for space and resources and fall prey to herbivory (Bowers et al., 2004). That desert marigold thrived only in plots with treatments $\mathrm{T}+\mathrm{M}$ and $\mathrm{S}+\mathrm{M}$ is additional evidence for the suitability of adding mulch prior to planting. The plots with treatments $\mathrm{S}+\mathrm{M}$ and $\mathrm{T}+\mathrm{M}$ not only showed the highest overall native plant densities, but also higher native plant diversity with high incidences of desert marigold, Indian tea, shadscale, four-wing saltbrush, and Indian ricegrass from seed. Although the overall difference in native plant densities between mulched and un-mulched plots in FY20 was not significant ( $\mathrm{p}=0.07$, two-tailed t-test with unequal variance), this is likely attributable to the high variance observed between individual plant species.

Shadscale and four-wing saltbrush from seed were observed with more frequency in FY20, the final year of the project. The increased rainfall in winter 2019/2020 could have aided in additional germination of these species because germination in both species is thought to be negatively affected by notable moisture stress (Springfield, 1970; Stidham et al. 1980), although shadscale is also known to be generally slow to germinate, with two or more spring seasons often required in field seed banks until germination occurs (Meyer et al., 1998). Both species develop into large-volume shrubs that could be considered keystone species in this environment. The increased seedling densities in FY20 highlight the importance of plot maintenance (watering, spiritual management through consistent Tribal interactions) over multiple years to allow these species to develop from seed. The TRC members interpreted this finding as further evidence of the patience and time required to allow plants to develop in a slow-growing ecosystem, creating healing. A TRC member 
explained, "...we found out the seeds are growing three years later instead of that following year. Sometimes it takes things a little while to acclimate to their new environment, because that's a new environment for them. And as they start to acclimate, and learning how to live, sprout, and grow." The TRC members pointed out that species that germinated in the third year of the project, such as Indian tea and Indian ricegrass, have essential cultural attributes for Numic peoples. The TRC members reiterated this is another example that it takes a good heart and recognition of the value of patience to allow the land to recover and thrive.

Table 7. Heat-map table showing most commonly observed native plants by plot treatment (average plant density as plant $\left./ \mathrm{m}^{2}\right)$ in $10 \mathrm{~m} \times 10 \mathrm{~m}(32.8 \mathrm{ft} \times 32.8 \mathrm{ft})$ plots corresponding to planting events during all fiscal years. Orange colors indicate lower plant densities, green colors indicate higher plant densities, and yellow colors indicate midrange plant densities.

\begin{tabular}{|c|c|c|c|c|c|c|c|c|c|c|}
\hline $\begin{array}{c}\text { Fiscal } \\
\text { Year }\end{array}$ & $\begin{array}{l}\text { Planting } \\
\text { time }\end{array}$ & Treatment & $\begin{array}{c}\text { Desert } \\
\text { globemallow }\end{array}$ & $\begin{array}{c}\text { Desert } \\
\text { marigold }\end{array}$ & $\begin{array}{l}\text { Four-wing } \\
\text { saltbush }\end{array}$ & $\begin{array}{c}\text { Indian } \\
\text { ricegrass }\end{array}$ & Indian tea & Creosote & Shadscale & $\begin{array}{c}\text { Overall } \\
\text { Average } \\
\text { Plants/m² }\end{array}$ \\
\hline \multirow{10}{*}{ FY18 } & \multirow{5}{*}{ Fall } & $\mathrm{S}+\mathrm{M}$ & 0.00 & 1.33 & 0.00 & 1.56 & 0.11 & 0.00 & 0.00 & 3.00 \\
\hline & & St & 0.00 & 0.78 & 0.17 & 3.11 & 0.11 & 0.00 & 0.11 & 4.28 \\
\hline & & $\mathrm{T}+\mathrm{S}+\mathrm{St}$ & 0.00 & 0.33 & 0.00 & 1.42 & 0.00 & 0.00 & 0.00 & 1.75 \\
\hline & & $\mathrm{T}+\mathrm{M}$ & 0.50 & 2.17 & 0.00 & 0.44 & 0.00 & 0.00 & 0.00 & 3.11 \\
\hline & & Control & 0.00 & 0.00 & 0.00 & 0.11 & 0.00 & 0.00 & 0.00 & 0.11 \\
\hline & \multirow{5}{*}{ Spring } & $\mathrm{S}+\mathrm{M}$ & 0.06 & 3.03 & 0.06 & 0.58 & 0.06 & 0.22 & 0.00 & 4.00 \\
\hline & & St & 0.00 & 0.06 & 0.00 & 0.00 & 0.00 & 0.00 & 0.00 & 0.06 \\
\hline & & $\mathrm{T}+\mathrm{S}+\mathrm{St}$ & 0.00 & 0.89 & 0.00 & 0.00 & 0.06 & 0.00 & 0.00 & 0.94 \\
\hline & & $\mathrm{T}+\mathrm{M}$ & 0.78 & 1.39 & 0.22 & 0.17 & 0.11 & 0.11 & 0.00 & 2.78 \\
\hline & & Control & 0.00 & 0.00 & 0.00 & 0.00 & 0.00 & 0.00 & 0.00 & 0.00 \\
\hline \multirow{10}{*}{ FY19 } & \multirow{5}{*}{ Fall } & $\mathrm{S}+\mathrm{M}$ & 0.04 & 0.81 & 0.00 & 0.04 & 0.00 & 0.00 & 0.00 & 0.90 \\
\hline & & St & 0.00 & 0.00 & 0.00 & 0.13 & 0.00 & 0.00 & 0.00 & 0.13 \\
\hline & & $\mathrm{T}+\mathrm{S}+\mathrm{St}$ & 0.00 & 0.00 & 0.00 & 0.00 & 0.00 & 0.00 & 0.00 & 0.00 \\
\hline & & $\mathrm{T}+\mathrm{M}$ & 0.00 & 0.25 & 0.04 & 0.04 & 0.04 & 0.04 & 0.00 & 0.42 \\
\hline & & Control & 0.00 & 0.00 & 0.00 & 0.00 & 0.00 & 0.00 & 0.00 & 0.00 \\
\hline & \multirow{5}{*}{ Spring } & $\mathrm{S}+\mathrm{M}$ & 0.08 & 1.04 & 0.00 & 0.38 & 0.00 & 0.00 & 0.00 & 1.50 \\
\hline & & St & 0.00 & 0.00 & 0.00 & 0.92 & 0.00 & 0.00 & 0.00 & 0.92 \\
\hline & & $\mathrm{T}+\mathrm{S}+\mathrm{St}$ & 0.17 & 0.04 & 0.00 & 0.00 & 0.00 & 0.00 & 0.00 & 0.21 \\
\hline & & $\mathrm{T}+\mathrm{M}$ & 0.08 & 0.38 & 0.00 & 0.00 & 0.00 & 0.00 & 0.00 & 0.46 \\
\hline & & Control & 0.00 & 0.00 & 0.00 & 0.13 & 0.00 & 0.00 & 0.00 & 0.13 \\
\hline \multirow{10}{*}{ FY20 } & \multirow{5}{*}{ Fall } & $\mathrm{S}+\mathrm{M}$ & 0.00 & 0.17 & 0.00 & 0.00 & 0.25 & 0.00 & 0.25 & 0.67 \\
\hline & & St & 0.00 & 0.00 & 0.00 & 0.08 & 0.00 & 0.00 & 0.00 & 0.08 \\
\hline & & $\mathrm{T}+\mathrm{S}+\mathrm{St}$ & 0.00 & 0.00 & 0.08 & 0.00 & 0.00 & 0.00 & 0.08 & 0.17 \\
\hline & & $\mathrm{T}+\mathrm{M}$ & 0.00 & 0.42 & 0.25 & 0.08 & 0.17 & 0.00 & 0.00 & 0.92 \\
\hline & & Control & 0.00 & 0.00 & 0.00 & 0.00 & 0.00 & 0.00 & 0.08 & 0.08 \\
\hline & \multirow{5}{*}{ Spring } & $\mathrm{S}+\mathrm{M}$ & 0.08 & 1.50 & 0.08 & 0.00 & 0.00 & 0.00 & 0.08 & 1.75 \\
\hline & & St & 0.00 & 0.00 & 0.00 & 0.08 & 0.00 & 0.00 & 0.08 & 0.17 \\
\hline & & $\mathrm{T}+\mathrm{S}+\mathrm{St}$ & 0.00 & 0.00 & 0.25 & 0.00 & 0.00 & 0.00 & 0.00 & 0.25 \\
\hline & & $\mathrm{T}+\mathrm{M}$ & 0.00 & 0.17 & 0.17 & 0.00 & 0.00 & 0.00 & 0.00 & 0.33 \\
\hline & & Control & 0.00 & 0.00 & 0.00 & 0.29 & 0.00 & 0.00 & 0.00 & 0.29 \\
\hline
\end{tabular}




\section{Qualitative Data}

Throughout the project, as quantitative monitoring data were collected within the $10 \mathrm{~m} \times 10 \mathrm{~m}(32.8 \mathrm{ft} \times 32.8 \mathrm{ft})$ plots, qualitative observations of animal signs and insect occurrences were concurrently recorded, as recommended by the TRC members.

Additionally, native plant seedlings inside the $10 \mathrm{~m} \times 10 \mathrm{~m}(32.8 \mathrm{ft} \times 32.8 \mathrm{ft})$ plot but outside the randomly placed $1 \mathrm{~m} \times 1 \mathrm{~m}(3.3 \mathrm{ft} \times 3.3 \mathrm{ft})$ counting square were also recorded. Although not quantitative, these data served as critical indictors for overall ecosystem health and functionality from the TRC perspective. The TRC members noted animals and insects help aerate roots, distribute seeds, and connect ecosystems through migratory pathways. The presence of animal and insects was documented throughout all years of plant monitoring (Figure 19), with a slight decline in each in FY20 that was attributed to the modified monitoring methods due to the COVID-19 pandemic. The reduction of the monitoring team from approximately five personnel to only two during FY20 with one TRC representative meant reduced spiritual management and less Tribal interactions with fewer eyes for qualitative observations. A TRC member speaks from the perspective of personified seeded plants and outplants during the pandemic and explains how they feel about abruptly reduced interactions: "Where did these people go? Did they abandon us? They were there. They're our protectors. They're here to protect these plants. ...nobody's talking to us, nobody's telling our stories of our ancestors. They have ancestors too."

Despite the reduction in monitoring members in FY20, more qualitative observations of native plant species were still recorded in all plot treatment types during the final year of the project (Figure 20). This overall increase in qualitatively observed native seedling diversity was considered an important attribute of the project. A TRC member explained that some of the native plants observed qualitatively were not part of the seed mix and they may have been brought in by animals, which is considered a healthy environmental indicator. He explained, "I think maybe animals are bringing them in. Like birds or rabbits. Whatever little types of animal or critter is out there... they're helping to pollinate stuff. Because they're coming out, and animals see those plants... and [say] I wanna hang out there, I need something from there, and they're dropping off little friends."
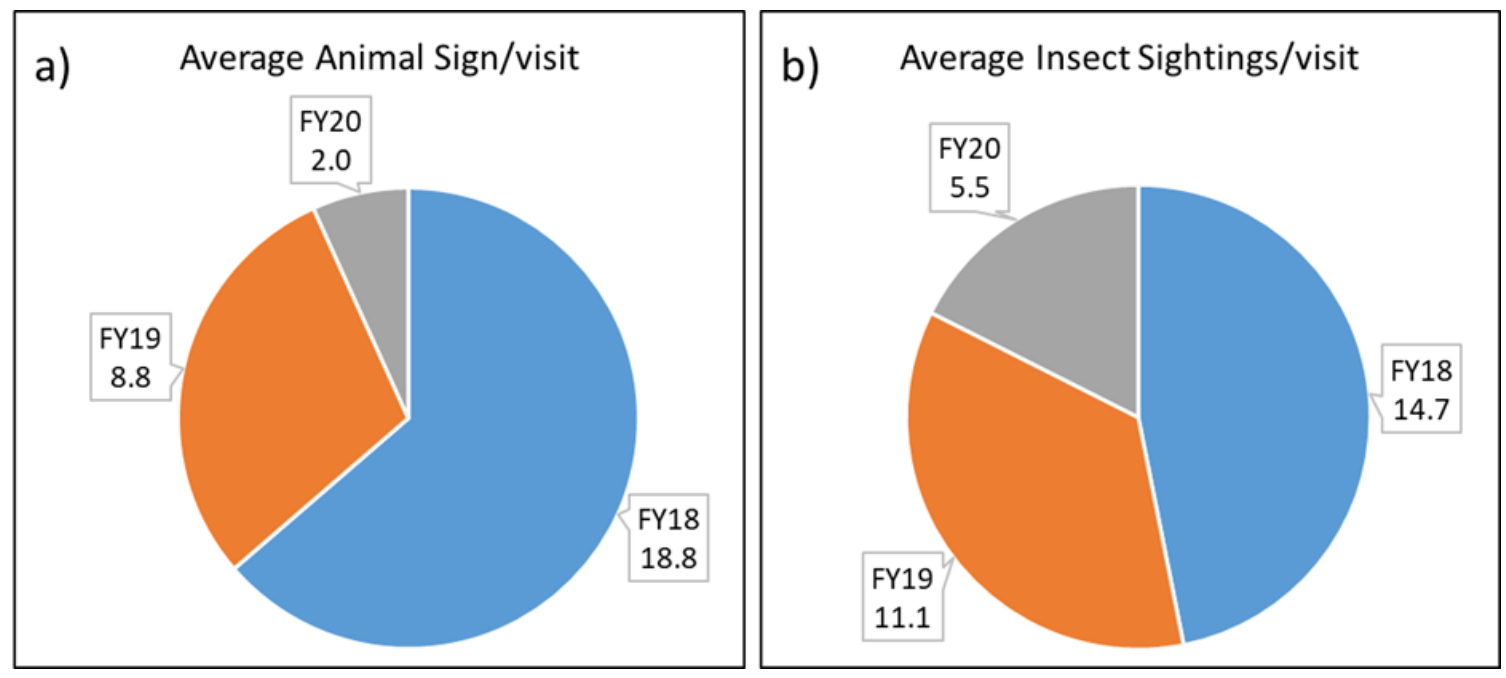

Figure 19. (a) Average animal signs observed per visit and (b) average insect observations per visit to the Tribal Revegetation Project site. 


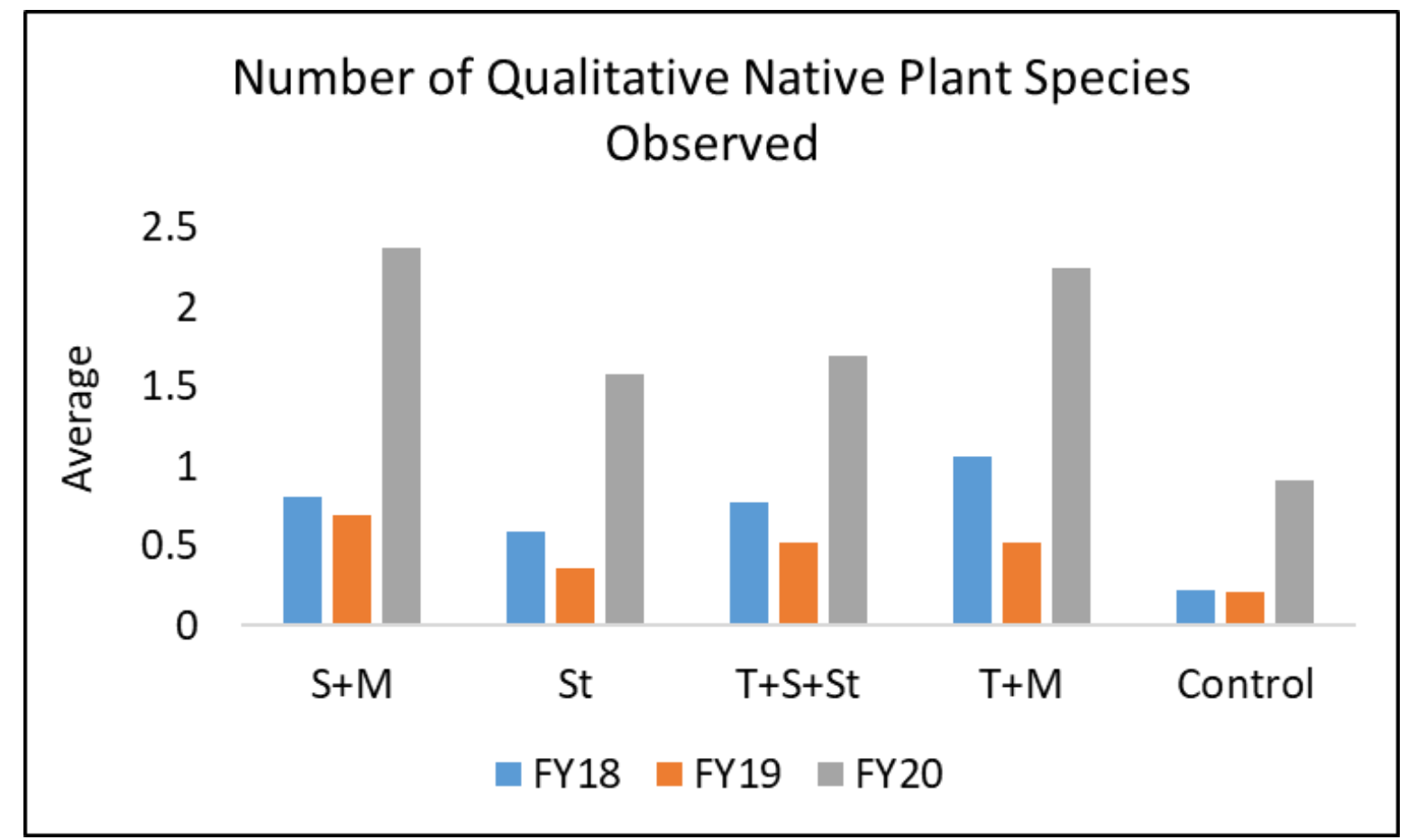

Figure 20. Average number of native species observed qualitatively in $10 \mathrm{~m} \times 10 \mathrm{~m}$ $(32.8 \mathrm{ft} \times 32.8 \mathrm{ft}$ ) plots per fiscal year (observed within $10 \mathrm{~m} \times 10 \mathrm{~m}[32.8 \mathrm{ft} \times 32.8 \mathrm{ft}]$ plots but outside the $1 \mathrm{~m} \times 1 \mathrm{~m}(3.3 \mathrm{ft} \times 3.3 \mathrm{ft})$ sampling square $)$.

\section{DISCUSSION OF EVALUATION METRIC}

\section{Tribal Definitions of Revegetation Success}

Numic peoples view revegetation success as something to be experienced. Revegetation is considered a process with no specific end point. The land is considered a holistic being with human relatives. Relationships with disturbed land requires constant nurturing and interaction for healing. The TRC members prefer calling revegetation efforts part of a program, not a project, so relationships initiated through revegetation can be sustained over time with respect and patience. It takes time to build a relationship with the land and understand the health of the land. The 92-Acre Area is a holistic site. It is impossible for Numic peoples to separate out the test plots from the environmental health and function of the entire 92-Acre Area and the NNSS in general (see the "Supplementary Materials" section for individual TRC member descriptions of revegetation success).

One of the most important environmental indicators of the test plot success according to the TRC members is the presence of animals (mammals, birds, reptiles, and amphibians) and insects. Such reunions occur through continuous Tribal interactions, propagating seeds, plant growth, outplants thriving, and animals and insects returning home. This is evidence of healing. In the words of a TRC member: "...there is a need for the ecological process to be balanced between animals and plants. Animals are needed...for the food chain to evolve...provide natural fertilizer...cultivation of the soils, [whose] tracks form [sh] allow deposits, nutrients and water to flow." 
Some native plant species that came to the test plots and the 92-Acre Area were not planted, and therefore they are signs of success because they are participating in the reunion of the healing ecosystem. According to the TRC members, "... we have seen ... [some species that we] didn't plant, but seeing [them] grow. Seeing mustard [with] little yellow flowers... [and] skeleton weed...we didn't plant ... are all native."

The TRC members shared that judging what is aboveground in the test plots is not the only indication of successful revegetation. According to a TRC member, "... what you see is aboveground, there is also things below ground. When it is aboveground there is more interaction with insect and birds, and feeding what is below. When whipping the trees have to remove it so that it becomes stronger underneath. They are forgetting that."

The TRC members further validated the empirical results of the revegetation study, which they helped conceptualize and implement. However, they caution that the findings are only a "snapshot of the entire process that included spiritual management and consistent Tribal interactions." A TRC member commented that "there's some good data there [in the empirical results] it showed a lot about the way the plants [seeds and outplants] started out and to how they are right now. Which is all positive. I don't see any negatives." The TRC added that seeded plants growing inside plots but outside of the selected $1 \mathrm{~m} \times 1 \mathrm{~m}$ $(3.3 \mathrm{ft} \times 3.3 \mathrm{ft})$ area and seeded plants growing outside of plots altogether indicated additional success. In the words of a TRC member: "...we know they [the seedlings and outplants] are from us." The TRC members consider plants growing in the control plots, outplants outgrowing cages, and outplants growing without irrigation to be other signs of success attributed to TEK. These environmental indicators are viewed as contributing elements of the much larger picture that support other areas around the 92-Acre Area.

\section{Blended TEK and Western Science Evaluation Metric}

In an effort to more objectively evaluate revegetation success, we combined TRC definitions (see above) with a numerical metric that meets contractual standards. In the early stages of this project, a proposed numerical metric was suggested to evaluate plant success. Upon subsequent discussions with the DOE, NDEP, and TRC, it became necessary to modify activities to propose a three-year revegetation study based on the Fieldwork Plan developed in collaboration with the TRC (Spoon and Barcalow, 2017) and use the results to determine a metric that could be implemented as a measure of success for future revegetation efforts. The TRC members caution that the following evaluation metric of plant survival is only a "snapshot of the entire revegetation process," which cannot be separated from spiritual management and consistent Tribal interactions. The intensity of the prayers coupled with implementing TEK at the onset of the revegetation effort reinforced the need for special cultural activities at the 92-Acre Area, including respect and patience for making relationships with the emerging ecosystem while conducting field observations and collecting revegetation data. Based on the overall native plant densities from seed achieved in all plot types (Table 7), an average plant density of 0.2 plants $/ \mathrm{m}^{2}\left(10.7 \mathrm{ft}^{2}\right)$ after three years is considered to be an appropriate overall numerical metric to support successful native plant establishment. This metric was achieved by six plot treatments in this study: fall-planted $\mathrm{S}+\mathrm{M}$ and $\mathrm{T}+\mathrm{M}$ plots; and spring-planted $\mathrm{S}+\mathrm{M}, \mathrm{T}+\mathrm{S}+\mathrm{St}, \mathrm{T}+\mathrm{M}$, and Control plots. However, treatments with higher native plant densities and higher corresponding plant diversity (e.g., 0.5 plants $/ \mathrm{m}^{2}\left[10.7 \mathrm{ft}^{2}\right]$ after three years with at least three native species established) may be preferred to promote a more sustainable and healthier ecosystem. This metric was achieved 
by three plot treatments in this study: fall-planted $\mathrm{S}+\mathrm{M}$ and $\mathrm{T}+\mathrm{M}$ plots, and spring-planted $\mathrm{S}+\mathrm{M}$ plots. These numerical metrics represent native plant establishment from seed, and the addition of outplants to a revegetation landscape is considered as a favorable way to jumpstart revegetation efforts. An outplant survival rate of 70 percent after three years is suggested as a suitable metric to indicate successful establishment of outplants. All springplanted, watered, non-control plots in this study readily achieved or surpassed this metric. Additionally, we recommend combining these numerical metrics with Tribal metrics of success to encourage a holistic ecosystem assessment of success that includes animal and insect presence. This reasonable goal will be attainable by supporting systematic Tribal inclusion in future revegetation efforts. According to the TRC, the success attained in this revegetation study is a result of the Tribal relationships with the land, which included opportunities to synthesize Tribal perspectives and observations of plant communities throughout the duration of the study. Plants will continue to thrive only if they are nurtured by the TRC members in a culturally appropriate manner, creating a reunion between Indigenous peoples and their homelands.

\section{TRC GUIDING PRINCIPLES}

The TRC members shared the following guidance through key principles to explain how to view and interact with the land at the 92-Acre Area. These principles frame the following recommendations:

1. The TRC does not support the storage of low-level radioactive waste or any nuclear testing activities on their ancestral lands, including the NNSS.

2. The TRC considers the test plots and broader 92-Acre Area part of a larger holistic landscape within the Numic ancestral territory.

3. Future revegetation efforts supported by the DOE should include appropriate Tribal representation from the onset and throughout the project.

4. The TRC, DOE EM NV, NDEP, PSU, DRI, and designated contractors must work collaboratively for revegetation success.

5. Tribal revegetation activities should become an ongoing program rather than a temporary project so that plants can be properly nurtured and balance can be sustained.

6. The TRC knows the land is unique and has many components that must be approached with integrated TEK to fully understand the cultural complexities at the 92-Acre Area. Receptiveness to innovative approaches and opportunities to sustain ecological balance remains critically important to healing the land, such as blending TEK with Western science approaches.

7. The TRC considers the metrics for success applied to the revegetation study to be tacit, or experiential knowledge learned over time, and empirical implicit results derived from the three-year revegetation study. Therefore, the TRC knows the importance of integrating different types of Tribal knowledge with Western science to evaluate and document revegetation success. 
8. The TRC believes the value of respect and cultural understanding of the ecosystem are essential elements for creating relationships between people and the land.

9. The TRC knows patience and time are critical when revegetating the area. Rushing the process will yield unfavorable results.

10. The DOE and contractors must view everything on the land as interconnected, sentient beings that need human interactions.

11. All individuals associated with the 92-Acre Area, including for revegetation, must maintain positive thoughts and speak from the heart.

12. The TRC views non-native plants as helpers for native plants that will eventually outcompete invasive plants. Everything has a purpose and is an important part of the ecosystem.

\section{TRC RECOMMENDATIONS}

The following recommendations reflect the next steps in the revegetation of the 92-Acre Area:

1. Integration of the cultural protocols described throughout this report should serve as a foundation for successful revegetation activities. Modification to systematic steps will result in different results.

2. Longer time intervals for field observations are needed to measure revegetation success. From the perspective of the TRC, three years is considered a short window to view and validate the development of this slow-growing ecosystem.

3. Consideration must be given to allotting a minimum of 30 days to review all draft documents and deliverables prior to submittal to ensure Tribal perspectives are appropriately represented.

4. Additional scientific analysis is needed on soils from the no-growth area to understand the different soil composition creating unsuitable conditions for revegetation. The initial findings identified incompatible soil, but more research is needed for future revegetation activities at the RWMC.

5. The success of the TRC is attributed to gender and ethnic group balance and support from a minimum of one spiritual leader from each ethnic group.

6. Development of a co-created revegetation plan for the entire 92-Acre Area should include TRC participation in tandem with the DOE and involvement from NDEP, PSU, and DRI.

7. The 92-Acre Area revegetation plan will require input from the TRC to replicate spiritual management, planting techniques, and Tribal interactions at the 92-Acre Area.

8. The co-created 92-Acre Area revegetation plan will include recommendation on whether to conduct revegetation in phases or all at once. 
9. Defining revegetation success provides clarity and understanding. Empirical results, as described in this report, should be supplemented by photographs and ongoing interviews with program participants

10. Spiritual management remains the cornerstone of project success. Corresponding activities should be integrated at the onset of the revegetation effort before land preparation or planting activities occur.

11. Spiritual management should be carried out in tandem with field observation, depending on the season, after prayers and songs are initially left on the land.

12. The TRC field observations should be conducted on a quarterly basis (three annually).

13. The DOE EM NV should support annual TRC meetings with the DOE, NDEP, DRI, and PSU to discuss results, Tribal observations, and experiences with the recommended adaptations to address emerging circumstances.

14. The TRC should present updates on Tribal revegetation activities at the annual Tribal Update Meeting between NNSA/NFO and the 16 American Indian Tribal nations and affiliated groups with cultural and historical ties to the NNSS

15. The TRC, PSU, and DRI should present the approach, results, and lessons learned from the 92-Acre Area study at appropriate conferences or other venues.

16. The TRC - in tandem with EM NV, NDEP, DRI, and PSU-should develop roles and responsibilities to define the next steps of Tribal involvement in revegetation at the 92-Acre Area.

17. The DOE staff and contractors should participate in cultural awareness training and training in Numic planting techniques before initiating planting activities or land disturbance.

18. Systematic contractor monitoring is necessary to ensure adherence to culturally appropriate protocols.

19. Ongoing Tribal monitoring and evaluation of plants associated with the existing Tribal Revegetation Project are necessary to observe and sustain long-term revegetation success. The relationships between Numic peoples and the study area were abruptly and unexpectedly modified during the COVID-19 pandemic, which perpetuated the separation and sense of isolation.

20. Initiate a new revegetation study in the larger 92-Acre Area to view revegetation success carried out by TRC members in collaboration with DRI and PSU. The study would include empirical data collection and spiritual management through ongoing Tribal interactions with the entire area.

21. The use of outplants/transplants and seeds from adjacent areas is the preferred method for revegetating the 92-Acre Area.

22. The use of the same plant species and outplants should be considered for revegetation and future studies. 
23. Tribal members, with involvement from trained biologists, should collect seeds and transplants from sites near the 92-Acre Area to start a seedbank for future RWMC revegetation activities.

24. The EM NV should support a Tribally operated plant nursey with a greenhouse to supply outplants if transplants are not available from nearby sites on the NNSS.

25. After implementation of the TEK-based methodology, a numerical metric of 0.2 plants $/ \mathrm{m}^{2}\left(10.7 \mathrm{ft}^{2}\right)$ after three years for seeded plant densities should be used to indicate a baseline for successful native plant establishment from seed. Alternatively, an overall metric of 0.5 plants $/ \mathrm{m}^{2}\left(10.7 \mathrm{ft}^{2}\right)$ after three years with a higher plant diversity (at least three different native plant species established) should be used as an indicator of a more sustainable and healthier ecosystem.

26. An outplant survival rate of 70 percent after three years, along with TRC indicators of success, should be used as a metric to indicate successful establishment of outplants.

27. Revegetation should include a spring planting with soil amendment, mulch, spiritual management, and consistent Tribal interactions because these conditions most consistently produced the highest outplant survival and native plant establishment from seed in this study.

28. Temporarily caging outplants/transplants is needed during planting to provide herbivory protection. Plant growth should be monitored to determine when the cage should be removed.

29. Consideration of amendments or treatments different from those presented in this work should occur in consultation with the TRC prior to approval by EM NV and NDEP.

30. Calibrating supplemental irrigation from natural precipitation levels should be used as a baseline. Irrigation should be incrementally decreased so that plants can adapt to the local precipitation.

31. Desert marigold should be used as an environmental indicator for native seeded species that will be sustained in subsequent growing seasons.

32. Outplants/transplants of four-wing saltbrush are a keystone species that provide shade and nutrients to the soil that allow other plants to thrive in subsequent years.

33. The EM NV should create a new video that documents the success of the Tribal Revegetation Project that complements the introductory video.

\section{PROPOSED NEXT STEPS FOR REVEGETATION AT THE 92-ACRE AREA AND BEYOND}

1. Convene a series of planning meetings with the TRC, DOE, DRI, PSU, and contractors to discuss needs and develop an implementation plan for scaling up the revegetation effort to include the entire 92-Acre Area. This plan will include a 
continuation of the existing cultural and scientific analyses to develop a workable strategy for the broader 92-Acre Area. Planning meetings can be used to identify suitable areas to support existing or future revegetation activities on the NNSS.

2. In conjunction with the TRC, establish an on-site greenhouse and plant nursery to provide seeds and transplants for revegetation initiatives at the RWMC and other NNSS locations.

3. Invite spiritual experts and the TRC team to the 92-Acre Area to share prayers on the land before, during, and after ground disturbance associated with revegetation efforts.

4. Provide opportunities for the TRC team to develop and present cultural awareness training for the DOE, contractors, and other personnel participating in overseeing and participating in land preparation and planting at the 92-Acre Area or surrounding area.

5. Develop mechanisms for the TRC team to monitor and provide guidance on contractor activities during land preparation, planting, and irrigation.

6. Quarterly field observation (monitoring) by the TRC team is necessary to sustain cultural relationships with the plants and the environment to provide proper spiritual management through consistent Tribal interactions. The TRC members will work closely with other Tribal representatives to train alternate TRC members to provide continuity and ensure the sustainability of Tribal interactions.

7. Sustaining annual meetings of the TRC, DOE, NDEP, TRC, and DRI to discuss the status of the revegetation effort, exchange information, and conduct spiritual management as determined necessary remains vital to sustaining collaborative relationships.

8. Sharing information with the 16 American Indian Tribal nations and affiliated groups with cultural and historical ties to the NNSS at annual meetings is important for providing updates and sustaining government-to-government interactions. Opportunities should be developed for representatives from the 16 American Indian Tribal nations and affiliated groups with cultural and historical ties to the NNSS to annually visit the 92-Acre Area to examine revegetation efforts and provide additional recommendations or interactions with the land.

9. Professional symposia and publications provide opportunities for the exchange of information to a broader audience. Consideration should be given to supporting the TRC team in presenting information about the Tribal Revegetation Study in the 92-Acre Area.

\section{CONCLUSION}

This effort represents a unique blended approach to revegetating an unnatural landscape with a high level of outside disturbance from the disposal of low-level radioactive waste on a raised, gently sloping landfill cover. It is progressive in both its methodology and the information it produced. Previous efforts failed three times to create a vegetative evapotranspirative cover at the 92-Acre Area in accordance with the FFACO. At the recommendation of the NSSAB, the DOE EM NV supported the Tribal Revegetation Project at the 92-Acre Area. The support of the DOE EM NV (Tiffany Gamero, Long-term 
Monitoring Activity Lead) and the NDEP (Christine Andres, Bureau of Federal Facilities Chief) were critical to the success of this effort. The gender-balanced TRC was formedrepresenting the three primary ethnic groups $N u w u, N e w e$, and Nuumu - to provide guidance on the next steps based on TEK. The need to care for the land, juxtaposed with the opposition to the storage of low-level radioactive waste and materials on ancestral land, was a challenging obstacle in this project. Despite the complexities of the epistemological views, the TRC relied on the responsibility of healing the land no matter the condition with the support of consistent Tribal interactions. The TRC conducted collaborative ethnographic interviews with spiritual leaders and a targeted literature review relevant to Indigenous knowledge of the area. Based on extensive Tribal recommendations, the group proposed a three-year revegetation study using seeds and outplants. The study randomly selected thirty $10 \mathrm{~m} \times 10 \mathrm{~m}(32.8 \mathrm{ft} \times 32.8 \mathrm{ft})$ plots and eight $10 \mathrm{~m} \times 100 \mathrm{~m}(32.8 \mathrm{ft} \times 328 \mathrm{ft})$ plots on the 92-Acre Area to conduct a variety of revegetation interventions based on TEK and supported by Western science. Although study plots were planted at the 92-Acre Area, numerous other plants were observed inside and outside of the study plots from broadcast seeding and natural conditions, which created more robust results.

Ongoing spiritual management was an integral component that guided the timing of plantings, soil amendments, adding mulch or straw, combining seeding with outplanting, and irrigation schedules. Traditional prayers were shared with the land at the onset and throughout the study. The TRC members collected empirical data in conjunction with DRI and PSU for further analysis. The TRC met with PSU and DRI for annual meetings to conduct spiritual management and discussed emerging circumstances and preliminary results. The TRC made presentations during the annual Tribal Update Meeting between NNSA/NFO and the 16 American Indian Tribal nations and affiliated groups with cultural and historical ties to the NNSS to provide Tribal representatives with the status of the project. Additionally, a visit to the RWMC was incorporated into the annual meeting so that Tribal representatives could view progress at the 92-Acre Area for additional context. Lastly, in-depth virtual ethnographic interviews were conducted with each TRC member after the entire five-year process to discuss Tribal perspectives relating to revegetation success and interpretations of the empirical results.

The results of the revegetation study serve as a foundation for sustaining spiritual management through consistent Tribal interactions from the onset and throughout the study. Based on overall TRC perspectives, the empirical results of the three-year revegetation study cannot be fully understood without recognizing the benefits of the spiritual management that occurred in tandem throughout the entire five-year project process. Without the spiritual management component, the results of future revegetation efforts will achieve much different results. Consistent Tribal interactions are integral to the success of the project and they provide an optimal time to collect empirical ecological data to further understand short-term and long-term ecosystem health. The TRC monitoring of contractors who carryout land preparation and planting activities is needed to ensure that the contractors are adhering to appropriate cultural protocols. Optimally, seeds and outplants should be collected and nurtured locally through a plant nursery with a greenhouse and Tribal participation. A seed bank could also be created from the plants grown in the greenhouse to support future EM NV activities. 
Cumulatively, this study found that spring is the optimal season to initiate planting after starting spiritual management of the specific areas within the 92-Acre Area. Seeding combined with outplanting, using the seed mix and outplant species specified in this study, appeared to yield the most desirable outcomes, as evidenced by both large keystone species and diverse native seedlings being concurrently established. Implementing a proper soil amendment and adding mulch based on soil conditions prior to planting fostered the most robust native plant establishment from seed. Regular irrigation of both outplants and seeded areas after planting was crucial to both plant survival and seed germination. After an initial establishment period, a reduction in irrigation was not found to negatively affect native plant survival. Initially caging the outplants resulted in low herbivory and removing these cages at strategic times as the plants matured was not found to negatively affect plant survival. Among outplants, four-wing saltbrush emerged as a keystone species of this ecosystem, showing more resilience to a wide range of watering and soil treatments than other outplant species. Of the seeded plants, desert marigold was an early environmental indicator, readily germinating and achieving high plant densities in all project years, with the most diverse native plant communities subsequently establishing from seed in plots with high desert marigold densities. Non-native plants were viewed as ecological forerunners whose heterogeneous establishment helped the disturbed, nutrient-deficient soil prepare for the transition into an emerging ecosystem, including native species. The results suggest that supplemental irrigation calibrated with annual precipitation and systematically tapered off as the plants matured helped the plants adapt to the natural precipitation cycle. Critically, animal and insect signs were indicators of successful revegetation efforts coupled with plant survival.

Based on the overall native plant densities from seed achieved in all plot types (Table 7), an average plant density of 0.2 plants $/ \mathrm{m}^{2}\left(10.7 \mathrm{ft}^{2}\right)$ after three years is considered an appropriate overall numerical metric to support successful native plant establishment. This metric was achieved by six plot treatments in this study: fall-planted $\mathrm{S}+\mathrm{M}$ and $\mathrm{T}+\mathrm{M}$ plots; and spring-planted $\mathrm{S}+\mathrm{M}, \mathrm{T}+\mathrm{S}+\mathrm{St}, \mathrm{T}+\mathrm{M}$, and Control plots. However, treatments with higher native plant densities and higher corresponding plant diversity (e.g., 0.5 plants $/ \mathrm{m}^{2}\left[10.7 \mathrm{ft}^{2}\right]$ after three years with at least three native species established) may be preferred to promote a more sustainable and healthier ecosystem. This metric was achieved by three plot treatments in this study: fall-planted $\mathrm{S}+\mathrm{M}$ and $\mathrm{T}+\mathrm{M}$ plots, and spring-planted $\mathrm{S}+\mathrm{M}$ plots. These numerical metrics represent native plant establishment from seed and the addition of outplants to a revegetation landscape is viewed as a favorable way to jump-start revegetation efforts. An outplant survival rate of 70 percent after three years is considered a suitable metric to indicate successful establishment of outplants. All spring-planted, watered, noncontrol plots in this study readily achieved or surpassed this metric. Additionally, it is critical that these numerical metrics are combined with Tribal metrics of success to encourage a holistic ecosystem assessment of success that includes animal and insect presence. These results were achieved through consistent Tribal interactions using spiritual management that reinforced the relationships made in healing the test plots and the 92-Acre Area in general.

This study demonstrates how combining multiple types of knowledge created appropriate solutions to complicated problems. It serves as a model for both healing the land and complying with federal policy in sustainable, progressive, and creative ways. New knowledge was developed that was rooted in Indigenous knowledge and enhanced by Western science. This approach helped make this project a success. The results show that this 
combination of tacit and implicit knowledge created a dynamic, emerging native ecosystem in the test plots at the 92-Acre Area, which was not possible during the three previous unsuccessful attempts to revegetate the area. The guiding principles and recommendations of this study should be used as a guide beyond the challenges at the 92-Acre Area so that other portions of the NNSS that require healing can be healed by their Indigenous relatives.

\section{SUPPLEMENTARY MATERIALS}

\section{Quantitative Data Used for Figure Construction}

constructed.

The following tables list the data from which the figures in the main text were

Table S-1a. Average annual percent survival rates of outplants in $10 \mathrm{~m} \times 10 \mathrm{~m}(32.8 \mathrm{ft} \times 32.8 \mathrm{ft})$ plots during all years for each outplant species type (standard deviations in parentheses).

\begin{tabular}{lccc|cc}
\hline \multirow{2}{*}{ Species } & Sample Period & \multicolumn{2}{c|}{ Fall/Winter } & \multicolumn{2}{c}{ Spring } \\
\cline { 2 - 6 } & & T+S+St & T+M & T+S+St & T+M \\
\hline \multirow{2}{*}{ Creosote bush } & FY18 & $36(19)$ & $50(24)$ & $94(14)$ & $100(0)$ \\
& FY19 & $31(35)$ & $54(25)$ & $96(8)$ & $98(6)$ \\
& FY20 & $17(0)$ & $33(0)$ & $100(0)$ & $100(0)$ \\
\hline \multirow{2}{*}{$\begin{array}{l}\text { Four-wing } \\
\text { saltbush }\end{array}$} & FY18 & $92(14)$ & $100(0)$ & $100(0)$ & $100(0)$ \\
& FY19 & $54(26)$ & $94(12)$ & $98(6)$ & $100(0)$ \\
& FY20 & $50(0)$ & $100(0)$ & $100(0)$ & $83(0)$ \\
\hline $\begin{array}{l}\text { Desert } \\
\text { globemallow }\end{array}$ & FY18 & $89(27)$ & $89(27)$ & $94(14)$ & $94(14)$ \\
& FY19 & $35(21)$ & $77(18)$ & $85(11)$ & $92(24)$ \\
\hline & FY20 & $33(0)$ & $67(0)$ & $67(0)$ & $88(8)$ \\
\hline
\end{tabular}


Table S-1b. Average plant height (in cm) of surviving outplants in $10 \mathrm{~m} \times 10 \mathrm{~m}(32.8 \mathrm{ft} \times 32.8 \mathrm{ft})$ plots during all years for each outplant species type (standard deviations in parentheses).

\begin{tabular}{lccc|cc}
\hline \multirow{2}{*}{ Species } & \multirow{2}{*}{ Sample Period } & \multicolumn{2}{c|}{ Fall/Winter } & \multicolumn{2}{c}{ Spring } \\
\cline { 2 - 6 } & & T+S+St & T+M & T+S+St & T+M \\
\hline \multirow{2}{*}{ Creosote bush } & FY18 & $22(11)$ & $36(5)$ & $31(3)$ & $35(3)$ \\
& FY19 & $15(12)$ & $36(6)$ & $35(3)$ & $39(3)$ \\
& FY20 & $23(1)$ & $42(2)$ & $39(2)$ & $46(2)$ \\
\hline \multirow{2}{*}{ Four-wing } & FY18 & $23(1)$ & $30(1)$ & $34(8)$ & $36(9)$ \\
saltbush & FY19 & $29(8)$ & $38(7)$ & $45(6)$ & $49(4)$ \\
& FY20 & $70(5)$ & $69(3)$ & $62(2)$ & $67(5)$ \\
\hline \multirow{2}{*}{$\begin{array}{l}\text { Desert } \\
\text { globemallow }\end{array}$} & FY18 & $28(7)$ & $30(4)$ & $37(15)$ & $33(17)$ \\
& FY19 & $29(17)$ & $32(13)$ & $40(13)$ & $37(17)$ \\
& FY20 & $56(9)$ & $53(2)$ & $55(2)$ & $56(2)$ \\
\hline
\end{tabular}

Table S-2a. Average percent survival in $10 \mathrm{~m} \times 100 \mathrm{~m}(32.8 \mathrm{ft} \times 328 \mathrm{ft}$ ) (outplant only) plots for all three years of monitoring (standard deviations of measurements across each season in parentheses).

\begin{tabular}{|c|c|c|c|c|c|c|c|c|c|}
\hline \multirow[b]{3}{*}{ Species } & \multirow[b]{3}{*}{$\begin{array}{r}\text { Sample } \\
\text { Period } \\
\end{array}$} & \multicolumn{4}{|c|}{ Fall/Winter } & \multicolumn{4}{|c|}{ Spring } \\
\hline & & Plot 1 & Plot 2 & Plot 3 & Plot 4 & Plot 5 & Plot 6 & Plot 7 & Plot 8 \\
\hline & & $\mathbf{W}+\mathbf{S}$ & $\mathbf{W}$ & $\mathbf{S}$ & Control & $\mathbf{W}+\mathbf{S}$ & W & $\mathbf{S}$ & Control \\
\hline \multirow{3}{*}{$\begin{array}{l}\text { Creosote } \\
\text { bush }\end{array}$} & FY18 & $71(11)$ & $82(4)$ & $60(39)$ & $51(19)$ & $95(5)$ & $94(9)$ & $100(0)$ & $95(8)$ \\
\hline & FY19 & $65(14)$ & $70(14)$ & $15(13)$ & $38(13)$ & $92(3)$ & $85(8)$ & $93(7)$ & $89(6)$ \\
\hline & FY20 & $30(5)$ & $50(0)$ & $3(5)$ & $31(4)$ & $91(0)$ & $82(0)$ & $90(0)$ & 77 (5) \\
\hline \multirow{3}{*}{$\begin{array}{l}\text { Four-wing } \\
\text { saltbush }\end{array}$} & FY18 & $98(4)$ & $98(4)$ & $89(13)$ & $85(20)$ & $97(5)$ & $85(12)$ & $94(4)$ & $93(8)$ \\
\hline & FY19 & $90(21)$ & $96(7)$ & $83(6)$ & $89(14)$ & $90(6)$ & $81(4)$ & $93(3)$ & $90(0)$ \\
\hline & FY20 & $100(0)$ & $100(0)$ & $90(4)$ & $91(0)$ & $91(0)$ & $80(0)$ & $88(5)$ & $90(0)$ \\
\hline \multirow{3}{*}{$\begin{array}{l}\text { Desert } \\
\text { globemallow }\end{array}$} & FY18 & $92(14)$ & $100(0)$ & $62(45)$ & $45(46)$ & $85(18)$ & $76(20)$ & $82(20)$ & $73(34)$ \\
\hline & FY19 & $78(18)$ & $98(4)$ & $28(13)$ & $17(16)$ & $67(5)$ & $67(5)$ & $41(22)$ & $67(25)$ \\
\hline & FY20 & $77(3)$ & $91(0)$ & $15(6)$ & $0(0)$ & $64(0)$ & $68(5)$ & $13(5)$ & $30(5)$ \\
\hline
\end{tabular}


Table S-2b. Average height $(\mathrm{cm})$ of surviving plants in $10 \mathrm{~m} \times 100 \mathrm{~m}(32.8 \mathrm{ft} \times 328 \mathrm{ft})$ (outplant only) plots for all three years of monitoring (standard deviations of measurements across each season in parentheses).

\begin{tabular}{|c|c|c|c|c|c|c|c|c|c|}
\hline \multirow[b]{3}{*}{ Species } & \multirow[b]{3}{*}{$\begin{array}{r}\text { Sample } \\
\text { Period }\end{array}$} & \multicolumn{4}{|c|}{ Fall/Winter } & \multicolumn{4}{|c|}{ Spring } \\
\hline & & Plot 1 & Plot 2 & Plot 3 & Plot 4 & Plot 5 & Plot 6 & Plot 7 & Plot 8 \\
\hline & & $\mathbf{W}+\mathbf{S}$ & $\mathbf{W}$ & $\mathbf{S}$ & Control & $\mathbf{W}+\mathbf{S}$ & $\mathbf{W}$ & $\mathbf{S}$ & Control \\
\hline \multirow{3}{*}{$\begin{array}{l}\text { Creosote } \\
\text { bush }\end{array}$} & FY18 & $37(6)$ & $32(3)$ & $21(5)$ & $41(6)$ & $33(5)$ & $39(5)$ & $28(1)$ & $27(2)$ \\
\hline & FY19 & $43(6)$ & $31(1)$ & $24(11)$ & $39(9)$ & $39(2)$ & 47 (4) & $34(2)$ & $31(3)$ \\
\hline & FY20 & $52(6)$ & $36(1)$ & $7(13)$ & $39(1)$ & $41(2)$ & $50(2)$ & $40(1)$ & $39(2)$ \\
\hline \multirow{3}{*}{$\begin{array}{l}\text { Four-wing } \\
\text { saltbush }\end{array}$} & FY18 & $33(6)$ & $28(5)$ & $20(3)$ & $25(4)$ & $36(12)$ & $38(10)$ & $27(4)$ & $30(5)$ \\
\hline & FY19 & $41(6)$ & $41(8)$ & $29(3)$ & $31(3)$ & $55(6)$ & $58(8)$ & $37(4)$ & $42(7)$ \\
\hline & FY20 & $61(4)$ & $63(3)$ & $48(7)$ & $48(4)$ & $74(5)$ & $86(7)$ & $50(3)$ & $64(4)$ \\
\hline \multirow{3}{*}{$\begin{array}{l}\text { Desert } \\
\text { globemallow }\end{array}$} & FY18 & $33(4)$ & $30(5)$ & $16(3)$ & $19(15)$ & $29(2)$ & $35(4)$ & $23(4)$ & $29(7)$ \\
\hline & FY19 & $42(14)$ & $45(15)$ & $24(7)$ & $16(12)$ & $52(17)$ & $51(16)$ & $25(7)$ & $36(18)$ \\
\hline & FY20 & $59(3)$ & $59(4)$ & $30(2)$ & $0(0)$ & $57(2)$ & $56(7)$ & $37(3)$ & $46(5)$ \\
\hline
\end{tabular}

Table S-3. Average plant densities, both native and invasive plants, on $10 \mathrm{~m} \times 10 \mathrm{~m}$ $(32.8 \mathrm{ft} \times 32.8 \mathrm{ft})$ plots, as observed in FY19 (February through June). Only native plants were part of the seed mix.

\begin{tabular}{llcc|cc}
\hline \multirow{2}{*}{ Treatment } & FY & \multicolumn{2}{c|}{ Native $\left(\mathbf{m}^{2}\right)$} & \multicolumn{2}{c}{ Invasive $\left(\mathbf{m}^{2}\right)$} \\
\cline { 2 - 6 } & & Fall/Winter & Spring & Fall/Winter & Spring \\
\hline \multirow{3}{*}{ S+M } & FY18 & 3.0 & 3.8 & 95.6 & 26.9 \\
& FY19 & 0.9 & 1.5 & 86.0 & 67.4 \\
& FY20 & 0.7 & 1.8 & 112.8 & 102.5 \\
\hline \multirow{3}{*}{$\mathrm{St}$} & FY18 & 4.3 & 0.1 & 60.0 & 12.8 \\
& FY19 & 0.1 & 0.9 & 74.7 & 65.4 \\
& FY20 & 0.1 & 0.2 & 87.3 & 58.8 \\
\multirow{3}{*}{$\mathrm{T}+\mathrm{S}+\mathrm{St}$} & FY18 & 1.7 & 0.9 & 76.9 & 17.0 \\
& FY19 & 0.0 & 0.2 & 76.5 & 71.0 \\
& FY20 & 0.2 & 0.3 & 89.3 & 57.8 \\
\multirow{3}{*}{$\mathrm{T}+\mathrm{M}$} & FY18 & 3.1 & 2.8 & 86.3 & 24.9 \\
& FY19 & 0.4 & 0.5 & 81.2 & 52.2 \\
& FY20 & 0.9 & 0.3 & 113.0 & 71.5 \\
\hline \multirow{2}{*}{ Control } & FY18 & 0.1 & 0.0 & 33.3 & 21.3 \\
& FY19 & 0.0 & 0.1 & 47.0 & 45.5 \\
& FY20 & 0.1 & 0.3 & 48.0 & 74.2 \\
\hline
\end{tabular}


Table S-4. Record of annual natural precipitation and irrigation rain equivalent. Total water (precipitation + irrigation) given for each year and average total water per month are calculated. All values are given in inches of rain equivalent (in). Spring plots were not planted until April 2018.

\begin{tabular}{l|cccc}
\hline & $\begin{array}{c}\text { Natural } \\
\text { Precipitation }\end{array}$ & $\begin{array}{c}\text { Irrigation Rain } \\
\text { Equivalent (in) }\end{array}$ & $\begin{array}{c}\text { Total } \\
\text { Annual } \\
\text { Water (in) }\end{array}$ & $\begin{array}{c}\text { Average Water } \\
\text { per Month (in) }\end{array}$ \\
\hline 2018 - fall plots & 2.8 & 31 & 34 & 2.8 \\
2018 - spring plots & 2.8 & 14 & 17 & 1.9 \\
2019 & 9.3 & 15 & 25 & 2.1 \\
2020 (through September) & 2.9 & 5 & 8 & 0.9 \\
\hline
\end{tabular}




\section{TRC Descriptions of Revegetation Success}

The following are descriptions by TRC members of how they define revegetation success in their own words:

For us, when we see the ants and the insects, boy-that was a success, those are the ones that are like the first arrivals. They'll be there first, then the animals will follow, and then the plants will be used. To me success is that the insects and animals are using the plants for what they're worth. Like you see all that rabbit poop, it means the rabbits are enjoying it-that's a success! - TRC Member.

When I see these pictures it's like OK, this makes me feel good and shows that we were part of it. Part of the at least give a little bit of life back to what wasn't there. In order to see the little things-even people don't think about that, from all the insects, the creepy-crawlers, and all of them coming back to the land. That's life, that's energy coming back into that land. For them to come back to it, we did something right you know in a sense of they must have felt to come back. So as that energy starts to build and expand and go out hopefully it will call more in and they'll start right even more. Even the birds are bringing more seeds, and the site will likely grow more.

- TRC Member

We were successful at growing plants out there when they've tried in the past. The land was really barren when we got there. Very few plants survived before we got there. And then after we left, and we were continuing to monitor and do this project they seem to flourish even when the watering has ceased or decreased. - TRC Member

The indicators are that the plants are coming back. Some of them are coming back even in the control where we don't do anything with them. The animals are definitely a sign of success because when they come back, they help pollinate the plants, which are going to help grow more, hopefully. - TRC Member

I think it was great. It was a great project. I mean it worked. I know we haven't been out there for a while, but still we were there, and we've seen all the progress as the little plants started growing and they got bigger and bigger. And we'd measure them, they're getting taller. I think it was a success...how the animals and the plants are always coming back now because and getting nutrients from the plants too. So, everybody is getting stuff out of this besides the people. So are the animals and the earth. Success. - TRC member

Ifeel the best about is not only seeing the plants thrive and grow but the animals. The animals I believe because I know for a fact that the animals were here on earth before man came to be in our beliefs, the Indians, the different Indians. They were here first, so I saw the animals out on the Area 5 and birds and lizards, toads and snakes, and that antelope close by and rabbit... that goes to show me that this is somehow with these plants growing is helping them come around to being in that area and doing 
better I'm not saying that humans are going to live there but you know for the plants that were planted there they're coming around and doing good that this is a good sign. - TRC Member

I think revegetation success is seeing the insects, and the little wildlife coming out there, like they're coming home. They see it as a home, and so therefore that's taking, because they, they know that difference in there, the only, they're the real landowners out there, is those creatures and they give the OK, they give the thumbs up, and by them being present, it's like we hit jack pot basically, so to speak. And more importantly, is seeing other plants that we haven't planted growing. And that's like they're invited, and they accepted it and claim it as their home too, so you know that, and that's what develops land, that's what develops natural life out there, it is when it's thriving and other plants say, "oh I wanna live here too" and they jump in, and then next thing you know.... - TRC Member 


\section{REFERENCES}

Abella, S.R., D.J. Craig, and A.A. Suazo, 2012. Outplanting not seeding establishes native desert perennials. Native Plants Journal, 13(2), pp. 81-90.

American Indian Writers Subgroup, 1996. Appendix G. American Indian Assessments: Final Environmental Impact Statement for the Nevada Test Site and Off-site Locations in the State of Nevada. U.S. Department of Energy Nevada Field Office, Las Vegas, NV.

Bainbridge, D., J. Tiszler, R. MacAller, and M.F. Allen, 2001. Irrigation and mulch effects on desert shrub transplant establishment. Native Plants Journal, 2(1), pp.25-29.

Barrow, J.R., K.M. Havstad, and B.D. McCaslin, 1997. Fungal root endophytes in fourwing saltbush, Atriplex canescens, on arid rangelands of southwestern USA. Arid Land Research and Management, 11(2), pp.177-185.

Benzarti, M., K.B. Rejeb, A. Debez, and C. Abdelly, 2013. Environmental and economic opportunities for the valorisation of the genus Atriplex: new insights. In Crop Improvement. Springer, Boston, MA, pp. 441-457.

Berkes, F., 2012. Sacred Ecology: Traditional Ecological Knowledge and Resource Management. Routledge, New York, NY.

Berkes, F., and N.L. Turner, 2006. Knowledge, learning, and the evolution of conservation practice for social-ecological system resilience. Human Ecology, 34(4):479-494.

Blaikie, N.W.H. 1991. A critique of the use of triangulation in social research. Quality and Quantity, 25(2):115-136.

Bowers, J.E., Turner, R.M. and Burgess, T.L., 2004. Temporal and spatial patterns in emergence and early survival of perennial plants in the Sonoran Desert. Plant Ecology 172(1), pp.107-119.

Brooks, M.L., 2000. Competition between alien annual grasses and native annual plants in the Mojave Desert. The American Midland Naturalist, 144(1), pp.92-108.

Brooks, M.L., 2003. Effects of increased soil nitrogen on the dominance of alien annual plants in the Mojave Desert. Journal of Applied Ecology, 40(2), pp.344-353.

Clary, R.F., and R.D. Slayback, 1983. Plant materials and establishment techniques for revegetation of California desert highways. Transportation Research Record, 969, pp. 24-26.

Clifford, M., and J. Spoon, 2018. Tribal Revegetation Project FY18 Annual Report, 92-Acre Area, Area 5 Radioactive Waste Management Complex, Nevada National Security Site, Nevada. Portland State University and Desert Research Institute, DOE/NV/0003590-30.

Duda, J.J., D.C. Freeman, J.M. Emlen, J. Belnap, S.G. Kitchen, J.C. Zak, E. Sobek, M. Tracy, and J. Montante, 2003. Differences in native soil ecology associated with invasion of the exotic annual chenopod, Halogeton glomeratus. Biology and Fertility of Soils, 38(2), pp. 72-77. 
Eckert, Jr., R.E., and F.E. Kinsinger, 1960. Effects of Halogeton glomeratus leachate on chemical and physical characteristics of soils. Ecology, 41, pp. 764-772.

Fidelibus, M., and R. MacAller, 1995. Appendix G: Techniques for Plant Establishment in Arid Ecosystems Restoration and Management Notes 13 (2): 190-197 1995 David A. Bainbridge. Restoration and Management Notes, 13(2), pp. 190-197.

Fowler, C.S., 1996. Historical perspectives on Timbisha Shoshone land management practices, Death Valley, California. In Case Studies in Environmental Anthropology, E. Reitz, C.M. Scarry, and S.J. Scudder (eds.). Plenum Press, New York, p. 87-101.

Fowler, C.S., and D. Garey-Sage. 2016. Isabel T. Kelly's Southern Paiute Ethnographic Field Notes, 1932-1934. Las Vegas. University of Utah Press, Salt Lake City,

Glenn, E., D. Moore, S. Sanderson, J.J. Brown, D. Lash, M. Nelson, and J. Waugh, 1998. Comparison of growth and morphology of Atriplex canescens varieties occidentalis and angustifolia. The Southwestern Naturalist, pp. 176-182.

Guo, H., Y.N. Cui, Y.Q. Pan, S.M. Wang, and A.K. Bao, 2020. Sodium chloride facilitates the secretohalophyte Atriplex canescens adaptation to drought stress. Plant Physiology and Biochemistry, 150, pp. 99-108.

Hall, D.B., and D.C. Anderson, 1999. Reclaiming disturbed land using supplemental irrigation in the Great Basin/Mojave Desert transition region after contaminated soils remediation: The Double Tracks project. In: USDA Proceedings RMRS-P-11: Shrubland Ecotones, pp. 260-265.

Hao, G.Y., M.E. Lucero, S.C. Sanderson, E.H. Zacharias, and N.M. Holbrook, 2013. Polyploidy enhances the occupation of heterogeneous environments through hydraulic related trade-offs in Atriplex canescens (Chenopodiaceae). New Phytologist, 197(3), pp. 970-978.

Hawkes, G., and G. Rowe. 2008. A characterization of the methodology of qualitative research on the nature of perceived risk: trends and omissions. Journal of Risk Research, 11(5):617-643.

Hill, R, Ç. Adem, W.V. Alangui, Z. Molnár, Y. Aumeeruddy-Thomas, P. Bridgewater, M. Tengö, R. Thaman, C.Y. Adou Yao, F. Berkes, J. Carino, M.C. da Cunha, M.C. Diaw, S. Díaz, V.E. Figueroa, J. Fisher, P. Hardison, K. Ichikawa, P. Kariuki, M. Karki, P.O.B. Lyver, P. Malmer, O. Masardule, A.A. Oteng Yeboah, D. Pacheco, T. Pataridze, E. Perez, M.M. Roué, H. Roba, J. Rubis, O. Saito, and D. Xue. 2020. Working with Indigenous, local and scientific knowledge in assessments of nature and nature's linkages with people. Current Opinion in Environmental Sustainability, 43:8-20.

Holzapfel, C., and B.E. Mahall, 1999. Bidirectional facilitation and interference between shrubs and annuals in the Mojave Desert. Ecology, 80(5), pp. 1,747-1,761.

Huntington, H.P., 2000. Using traditional ecological knowledge in science: Methods and applications. Ecological Applications 105:1270-1274. 
Kelly, I.T., and C.S. Fowler, 1986. Southern Paiute. In Handbook of North Americans Indians: Great Basin. W.L. D’Azevedo (ed.). Smithsonian Institution, Washington, D.C., pp. 368-397.

Kotanen, P.M., 1997. Effects of experimental soil disturbance on revegetation by natives and exotics in coastal California meadows. Journal of Applied Ecology, pp.631-644.

Meyer, S.E., Carlson, S.L. and Garvin, S.C., 1998. Seed germination regulation and field seed bank carryover in shadscale (Atriplex confertifolia: Chenopodiaceae). Journal of Arid Environments, 38(2), pp.255-267.

Moller, H., F. Berkes, P.O.B. Lyver, and M. Kislalioglu, 2004. Combining science and traditional ecological knowledge: monitoring populations for co-management. Ecology and Society, 9(3):2.

Ostler, K., 2015. Report Remedial Revegetation and Vegetation Monitoring CAU 111, South-North Closure Cover "92-Acre Site.” DOE/NV Report. Las Vegas, NV.

Pan, Y.X. and Wang, X.P., 2009. Factors controlling the spatial variability of surface soil moisture within revegetated-stabilized desert ecosystems of the Tengger Desert, Northern China. Hydrological Processes: An International Journal, 23(11), pp. 1,591-1,601.

Raymond, C.M., I. Fazey, M.S. Reed, L.C. Stringer, G.M. Robinson, and A.C. Evely, 2010. Integrating local and scientific knowledge for environmental management. Journal of Environmental Management, 91(8):1,766-1,777

Roundy, B.A., H. Heydari, C. Watson, S.E. Smith, B. Munda, and M. Pater, 2001. Summer establishment of Sonoran Desert species for revegetation of abandoned farmland using line source sprinkler irrigation. Arid Land Research and Management, 15(1), pp. 23-39.

Scoles-Sciulla, S.J., L.A. DeFalco, and T.C. Esque, 2015. Contrasting long-term survival of two outplanted Mojave Desert perennials for post-fire revegetation. Arid Land Research and Management, 29(1), pp.110-124.

Spoon, J., 2014. Quantitative, qualitative, and collaborative methods: Approaching Indigenous ecological knowledge heterogeneity. Ecology and Society 19(3):33.

Spoon, J., and R. Arnold, 2012. Collaborative research and co-learning: Integrating Nuwuvi (Southern Paiute) ecological knowledge and spirituality to revitalize a fragmented land. Journal for the Study of Religion, Nature, and Culture, 6.4:477-500.

Spoon, J., R. Arnold, B. Lefler, and C. Milton, 2015. Nuwuvi (Southern Paiute), shifting fire regimes, and the Carpenter One Fire in the Spring Mountains National Recreation Area, Nevada. Journal of Ethnobiology, 35(1):85-110.

Spoon, J., and K. Barcalow, 2016. Phase 1 Summary Report, Tribal Revegetation Project, Corrective Action Unit 110, Radioactive Waste Management Complex. Portland State University and Desert Research Institute, Portland, OR. DRI Report No. AI011216-1.

Spoon, J., and K. Barcalow, 2017. Tribal Revegetation Project Fieldwork Plan, 92-Acre Area, Area 5 Radioactive Waste Management Complex, Nevada National Security 
Site, Nevada. Portland State University and Desert Research Institute. DOE/NV/0003590-07.

Spoon, J., C.E. Hunter, D. Gerkey, R.B. Chhetri, A. Rai, U. Basnet, and A. Dewan, 2020. Anatomy of disaster recoveries: tangible and intangible recovery dynamics following the 2015 Nepal earthquakes. International Journal of Disaster Risk Reduction 51, 101879.

Springfield, H.W., 1970. Germination and Establishment of Fourwing Saltbush in the Southwest. USDA Forest Service Research Paper RM-55. Rocky Mountain Forest and Range Experiment Station, Fort Collins, CO, p. 48.

Stidham, N.D., Ahring, R.M., Powell, J. and Claypool, P.L., 1980. Chemical scarification, moist prechilling, and thiourea effects on germination of 18 shrub species. Rangeland Ecology \& Management/Journal of Range Management Archives, 33(2), pp.115-118.

Stoffle, R.W., M.N. Zedeño, and D.L. Halmo (eds.), 2001. American Indians and the Nevada Test Site: A Model of Research and Consultation. U.S. Government Printing Office, Washington D.C.

Stoffle, R.W., D.B. Halmo, J.E. Omsted, and M.J. Evans, 1990. Native American Cultural Resources Studies at Yucca Mountain, Nevada. The Institute for Social Research, the University of Michigan, Ann Arbor.

Thomas, D.W., L.S.A. Pendleton, and S.C. Cappannnari, 1986. Western Shoshone. In Handbook of North Americans Indians: Great Basin. W.L. D'Azevedo (ed.). Smithsonian Institution, Washington, D.C., pp. 262-283.

Titus, J.H., P.J. Titus, R.S. Nowak, and S.D. Smith, 2002. Arbuscular mycorrhizae of Mojave Desert plants. Western North American Naturalist, pp. 327-334.

Turner, N.J., and F. Berkes, 2006. Coming to understanding developing conservation through incremental learning in the Pacific Northwest. Human Ecology, 34:495-513.

Walker, L.R., and E.A. Powell, 1999. Effects of seeding on road revegetation in the Mojave Desert, southern Nevada. Ecological Restoration, 17(3), pp. 150-155.

White, H., 2002. Combining quantitative and qualitative approaches in poverty analysis. World Development, 30(3):511-522.

Woodward, E., S. Jackson, M. Finn, and P.M. McTaggart, 2012. Utilizing indigenous seasonal knowledge to understand aquatic resource use and inform water resource management in northern Australia. Ecological Management and Restoration, 13(1):58-64.

Zhao, H.L., R.L. Zhou, Y.Z. Su, H. Zhang, L.Y. Zhao, and S. Drake, 2007. Shrub facilitation of desert land restoration in the Horqin Sand Land of Inner Mongolia. Ecological engineering, 31(1), pp. 1-8.

Zent, S., 2012. A genealogy of scientific representations of indigenous knowledge. In Landscape, Process and Power: Reevaluating Traditional Environmental Knowledge. S. Heckler (ed.). Berghahn Books, Oxford, pp. 19-67. 
APPENDIX A. PHOTOGRAPHS FROM SELECT FY18, FY19, AND FY20 ACTIVITIES

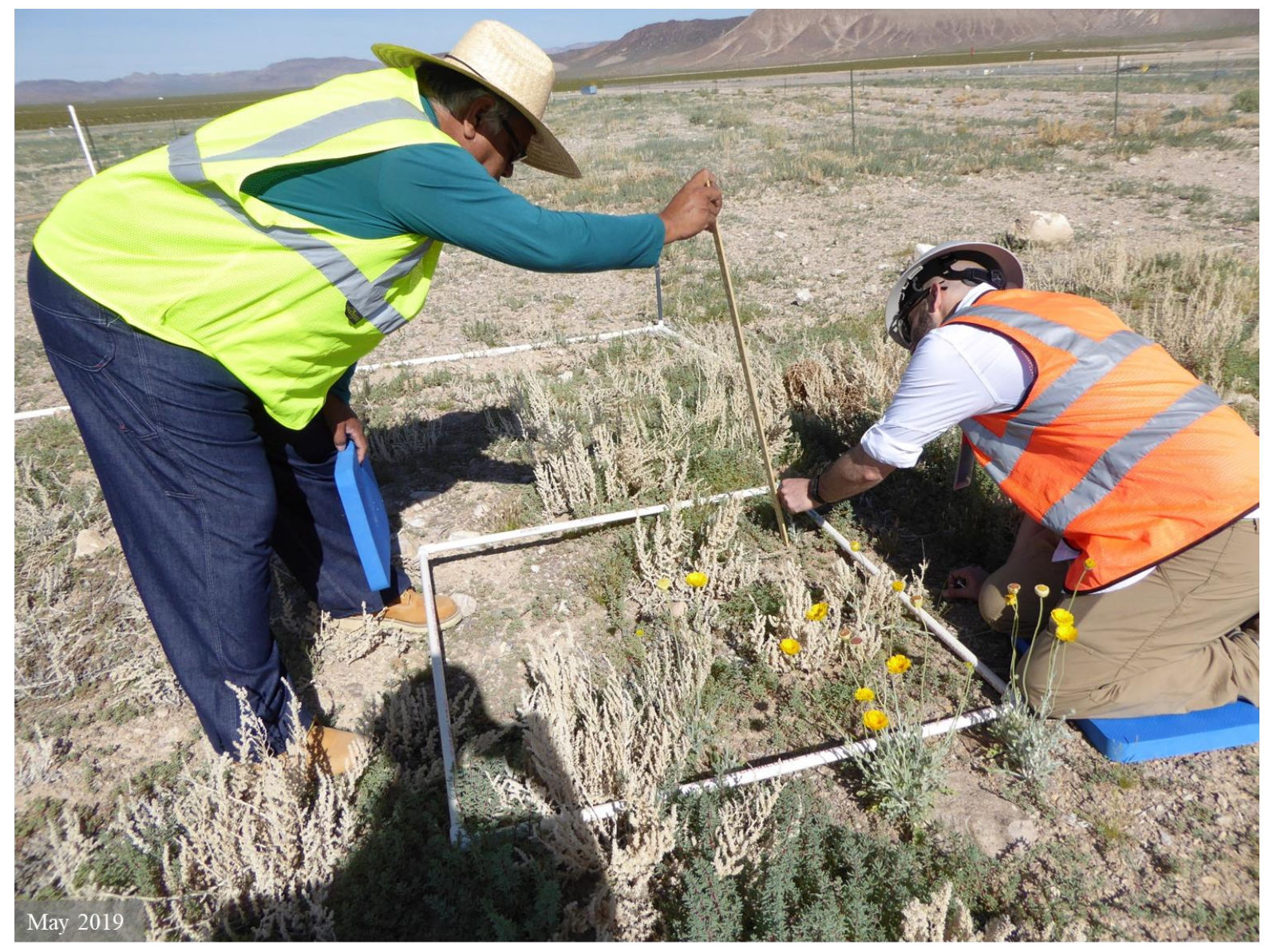

Figure A-1. Abundant flowering desert marigold in $10 \mathrm{~m} \times 10 \mathrm{~m}(32.8 \mathrm{ft} \times 32.8 \mathrm{ft})$ plot. 


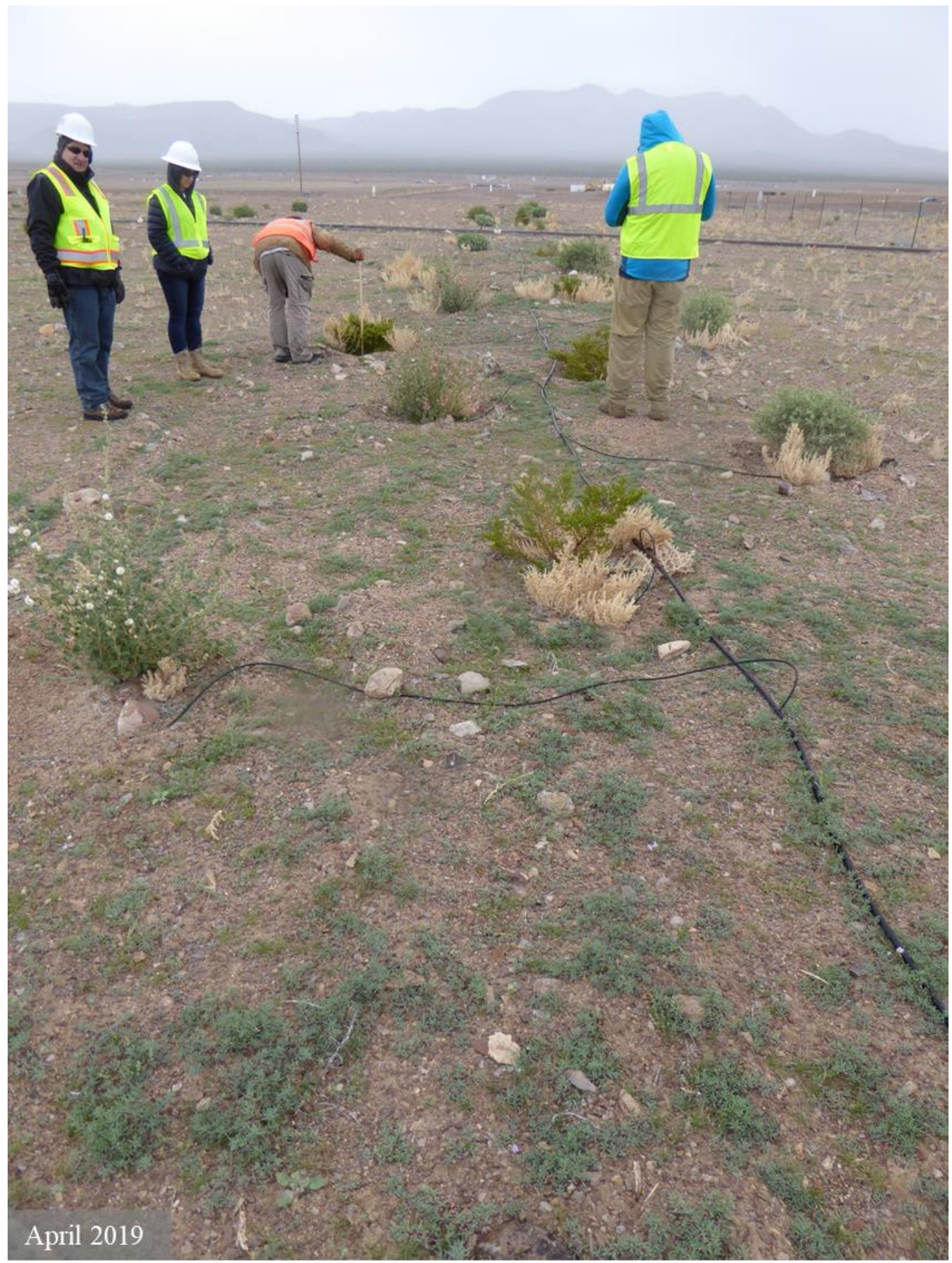

Figure A-2. Transplant plot $(10 \mathrm{~m} \times 100 \mathrm{~m}[32.8 \mathrm{ft} \times 328 \mathrm{ft}])$ from spring planting. 

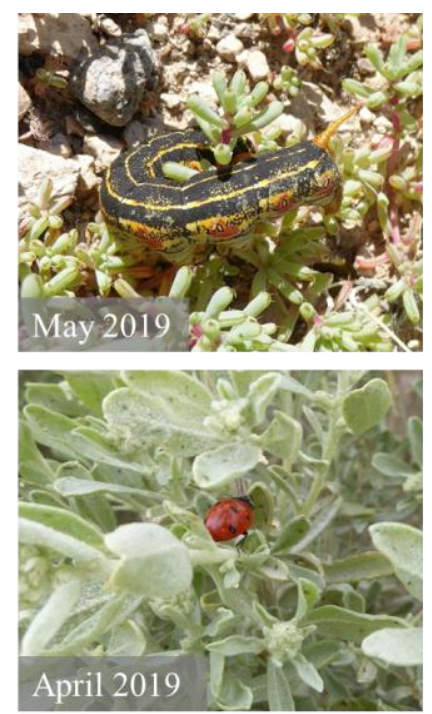
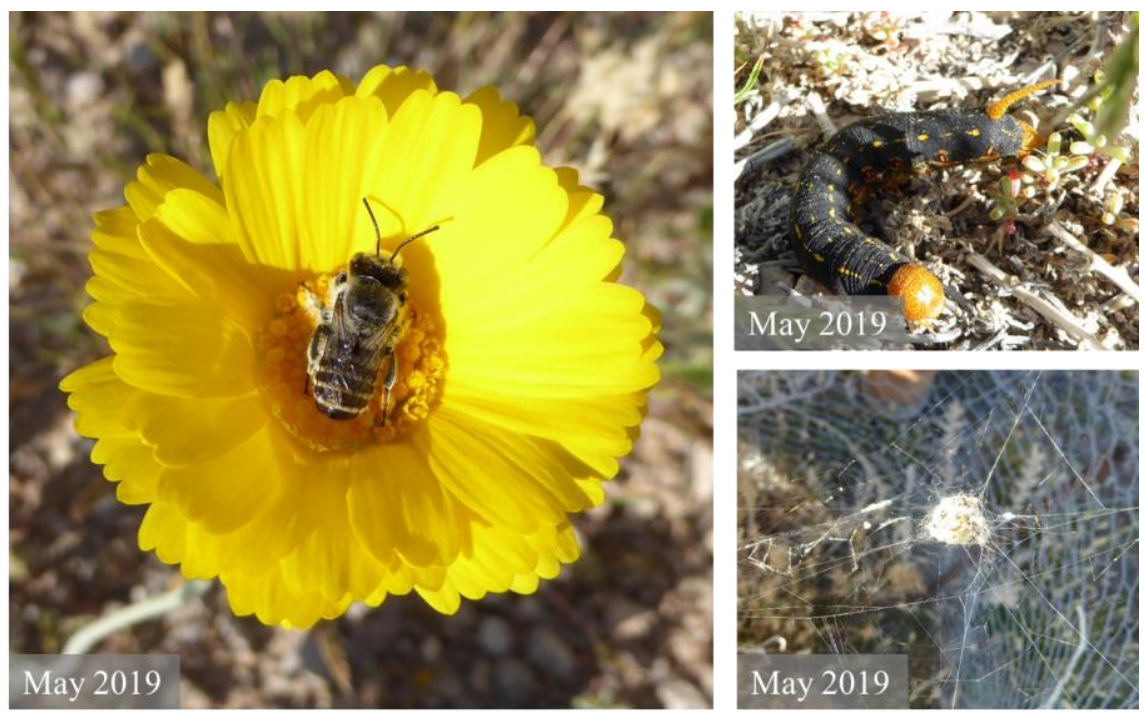

Figure A-3. Observations of insect and spider activity within study plots.
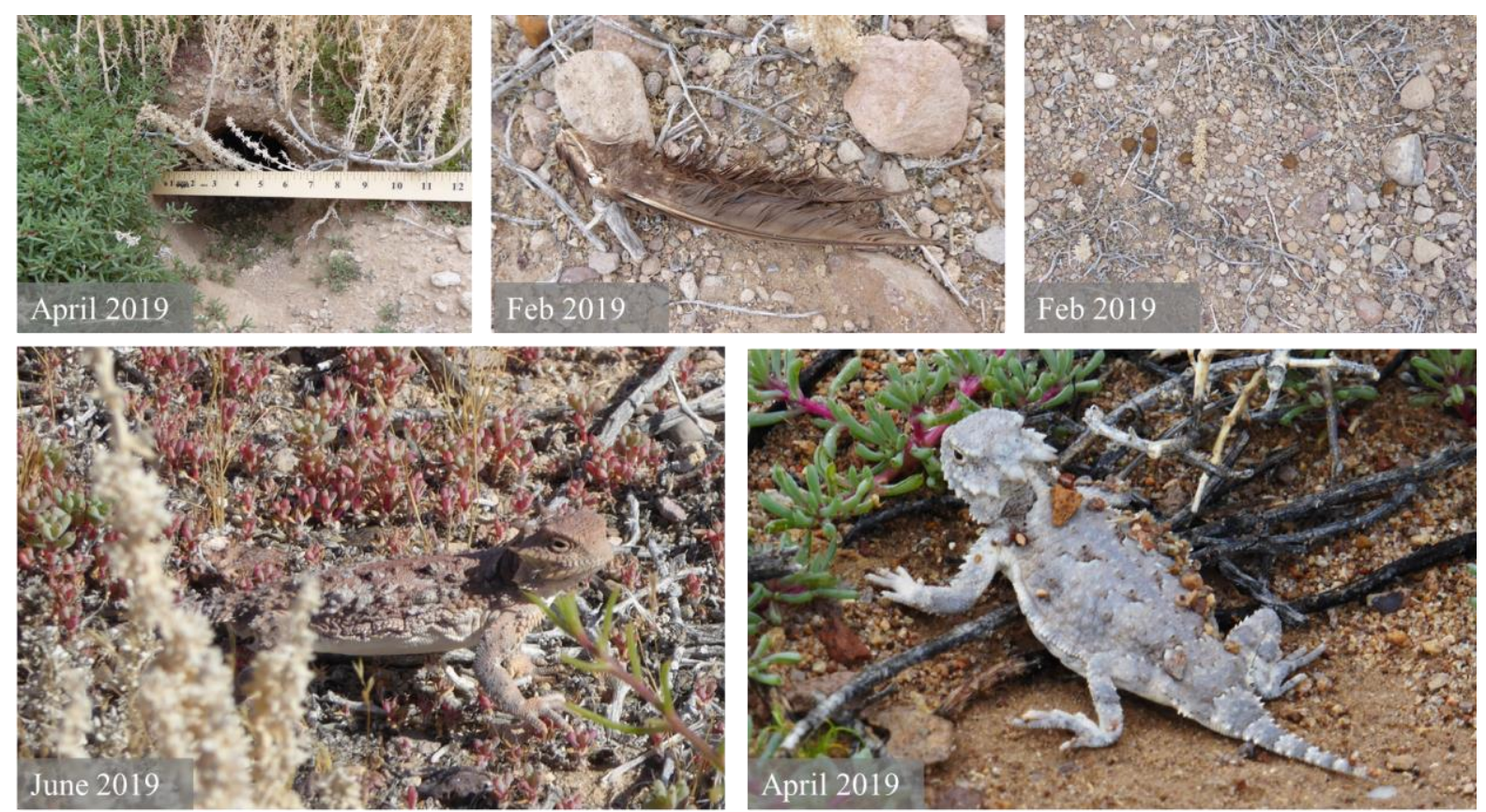

Figure A-4. Observations of wildlife (and evidence of wildlife) within study plots. 

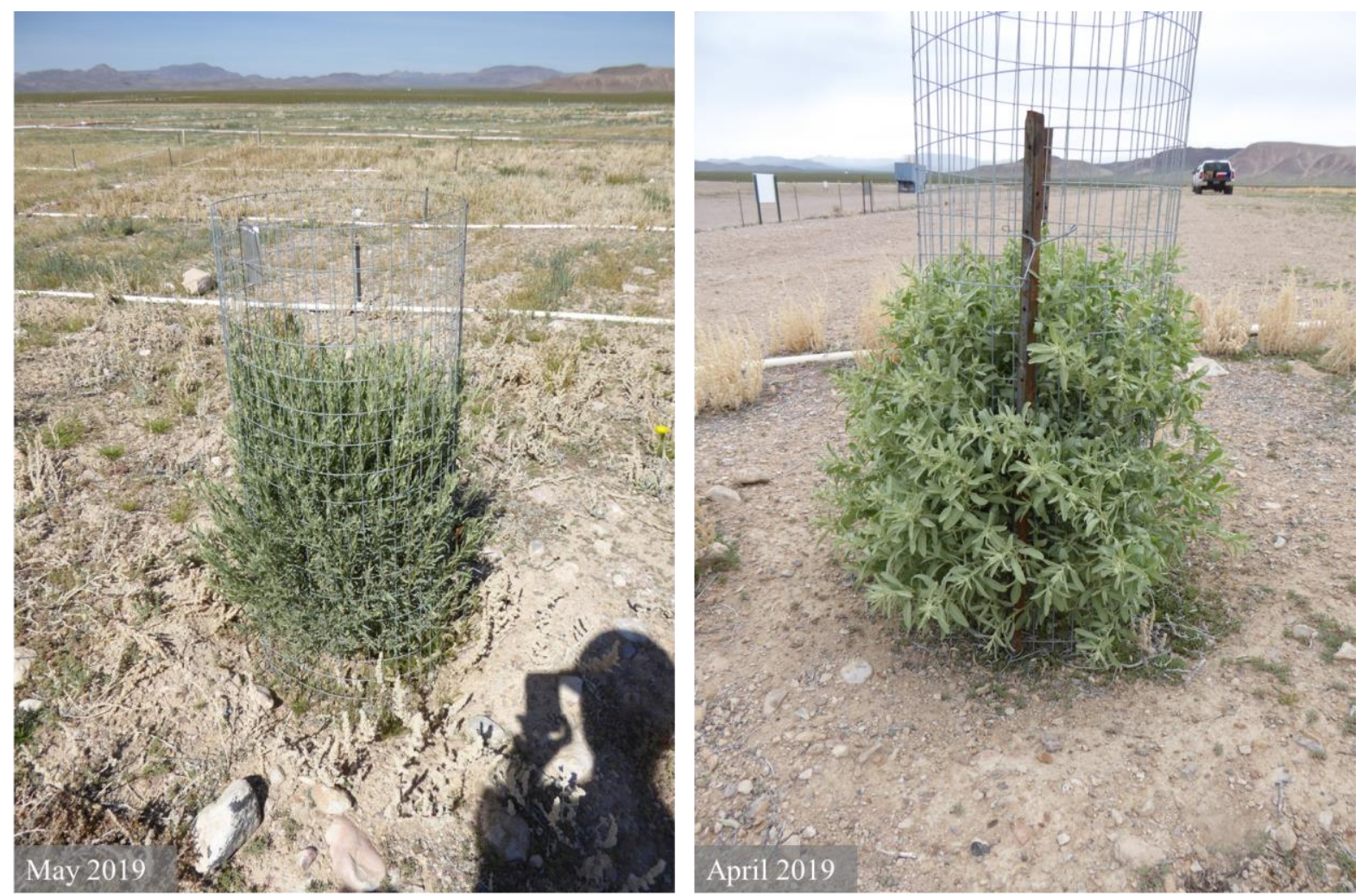

Figure A-5. Growth of transplants within $10 \mathrm{~m} \times 10 \mathrm{~m}(32.8 \mathrm{ft} \times 32.8 \mathrm{ft})$ plots require removal of fencing. 


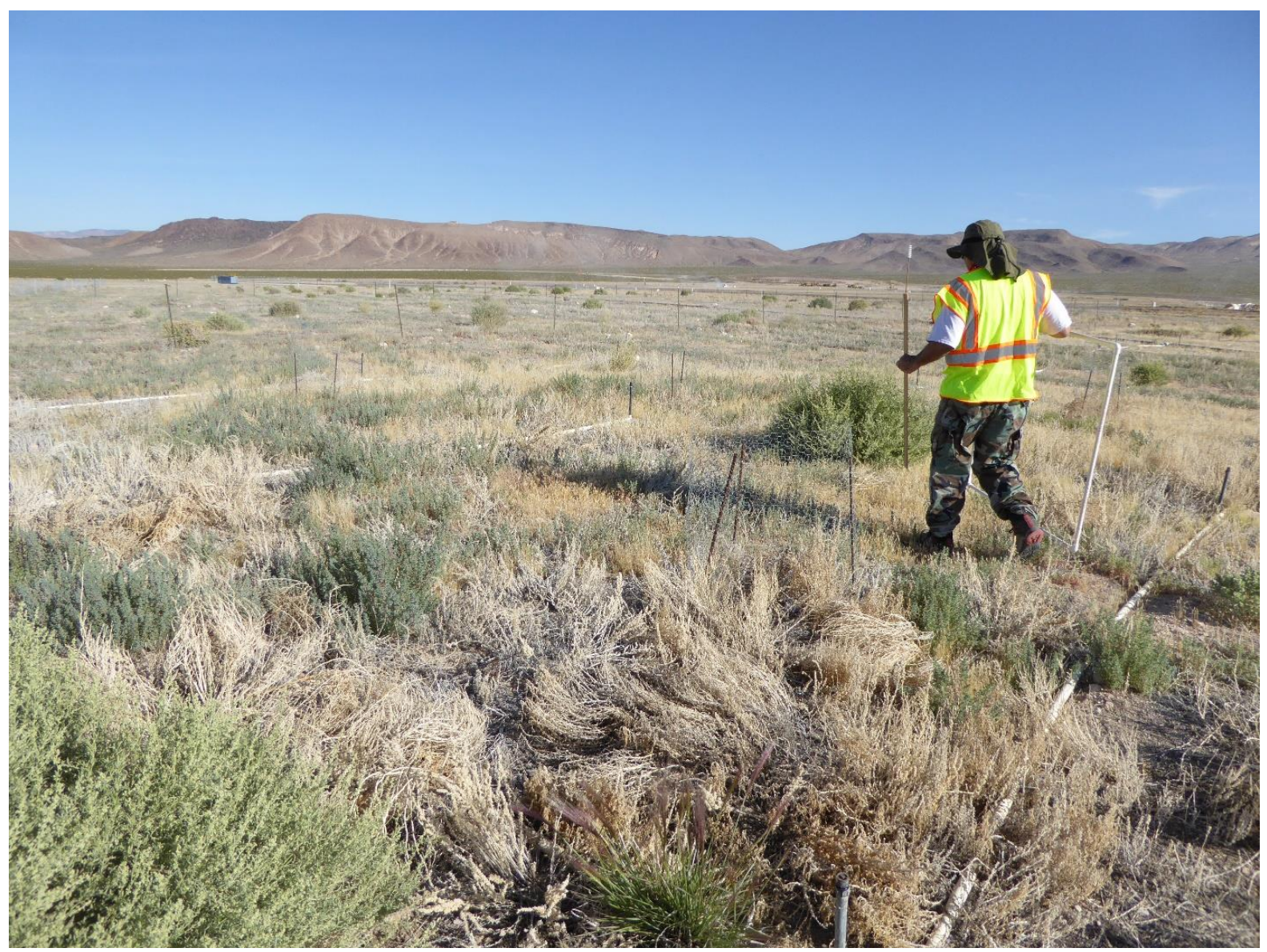

Figure A-6. A TRC member walks in a plot, with many established plants visible in the distance.
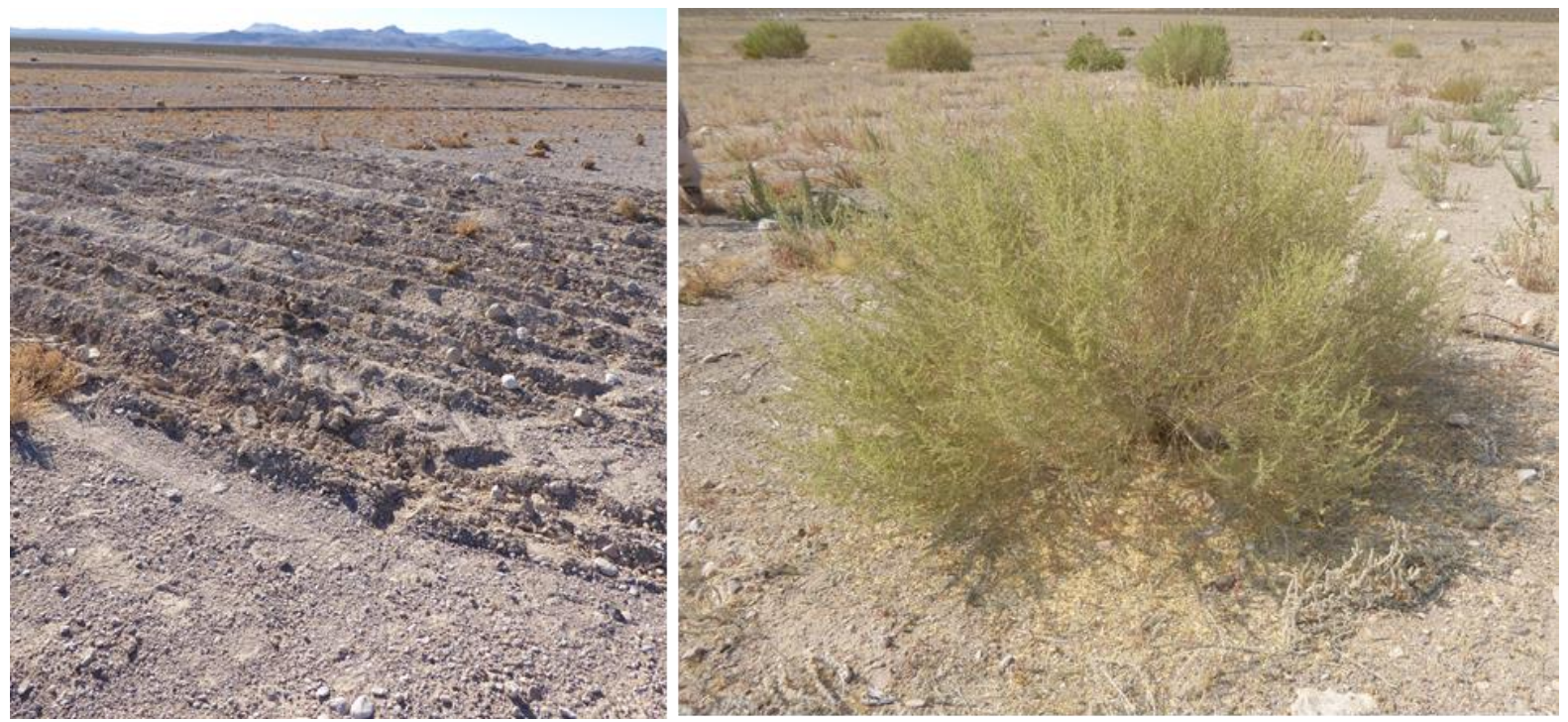

Figure A-7. The site during the December 2017 planting event (left) versus the currently established large four-wing saltbrush now on the site, as observed in September 2020 (right). 


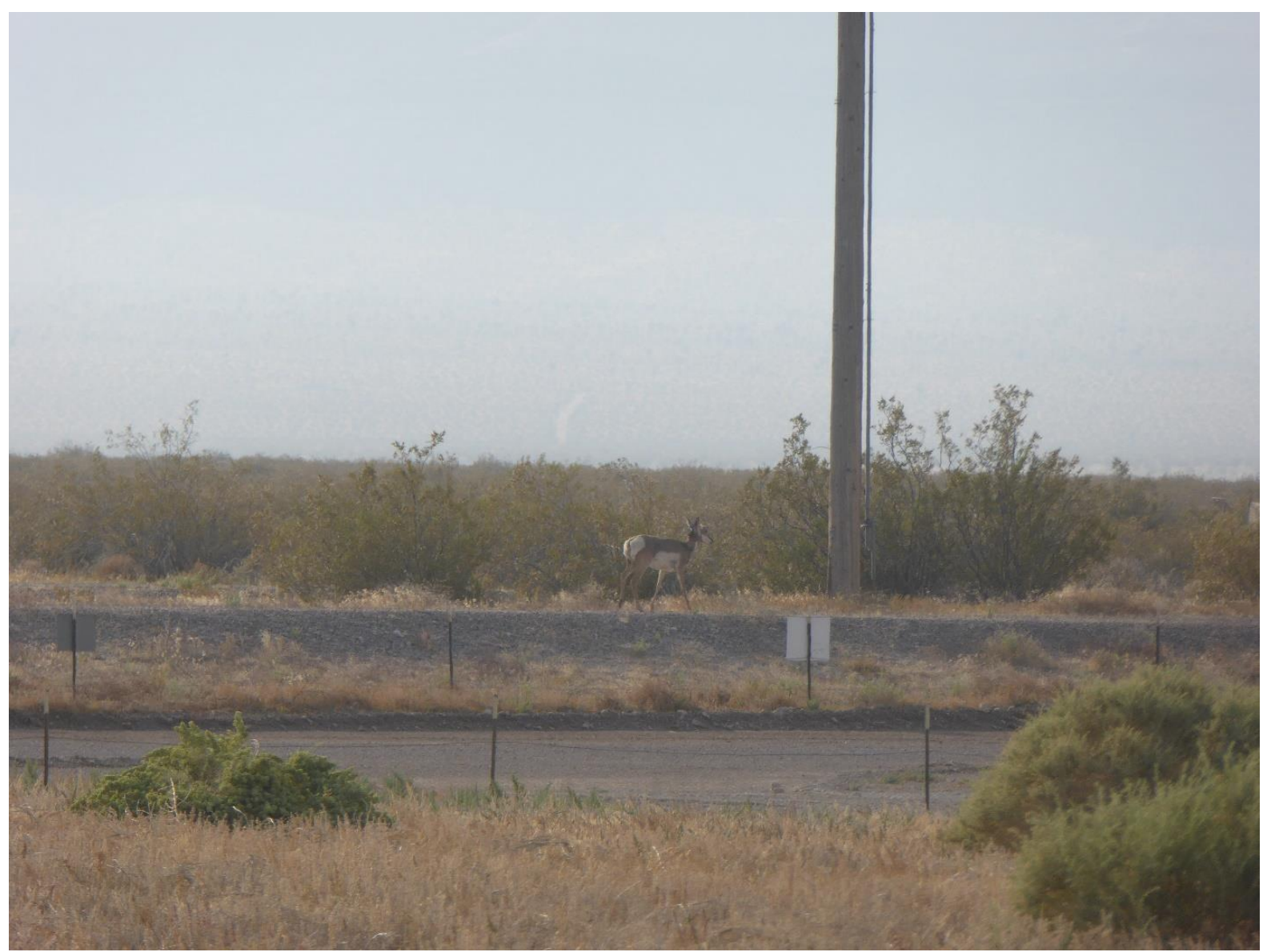

Figure A-8. An antelope visitor during the September 2020 monitoring. 


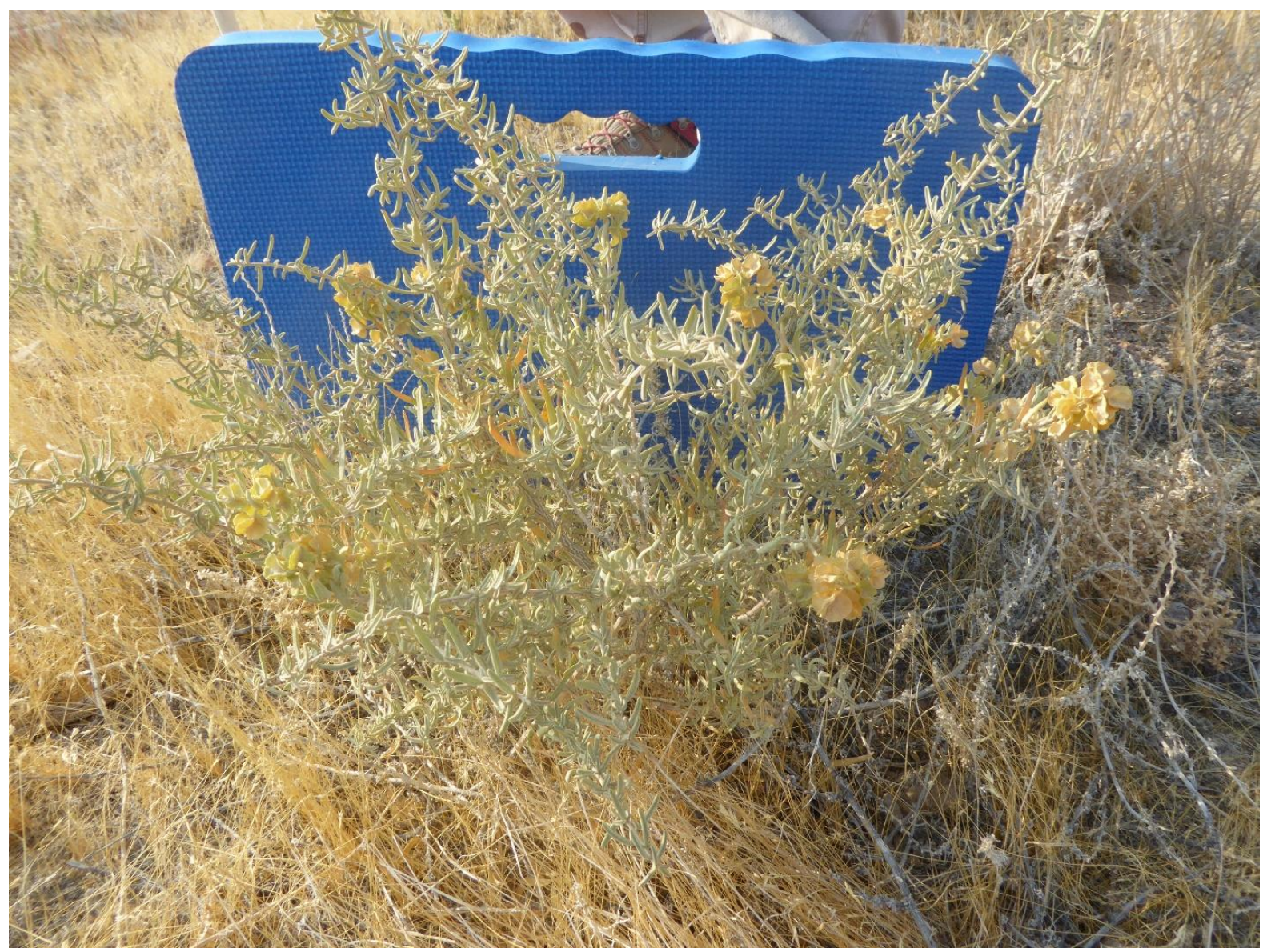

Figure A-9. A healthy four-wing saltbrush established from seed in a plot. 


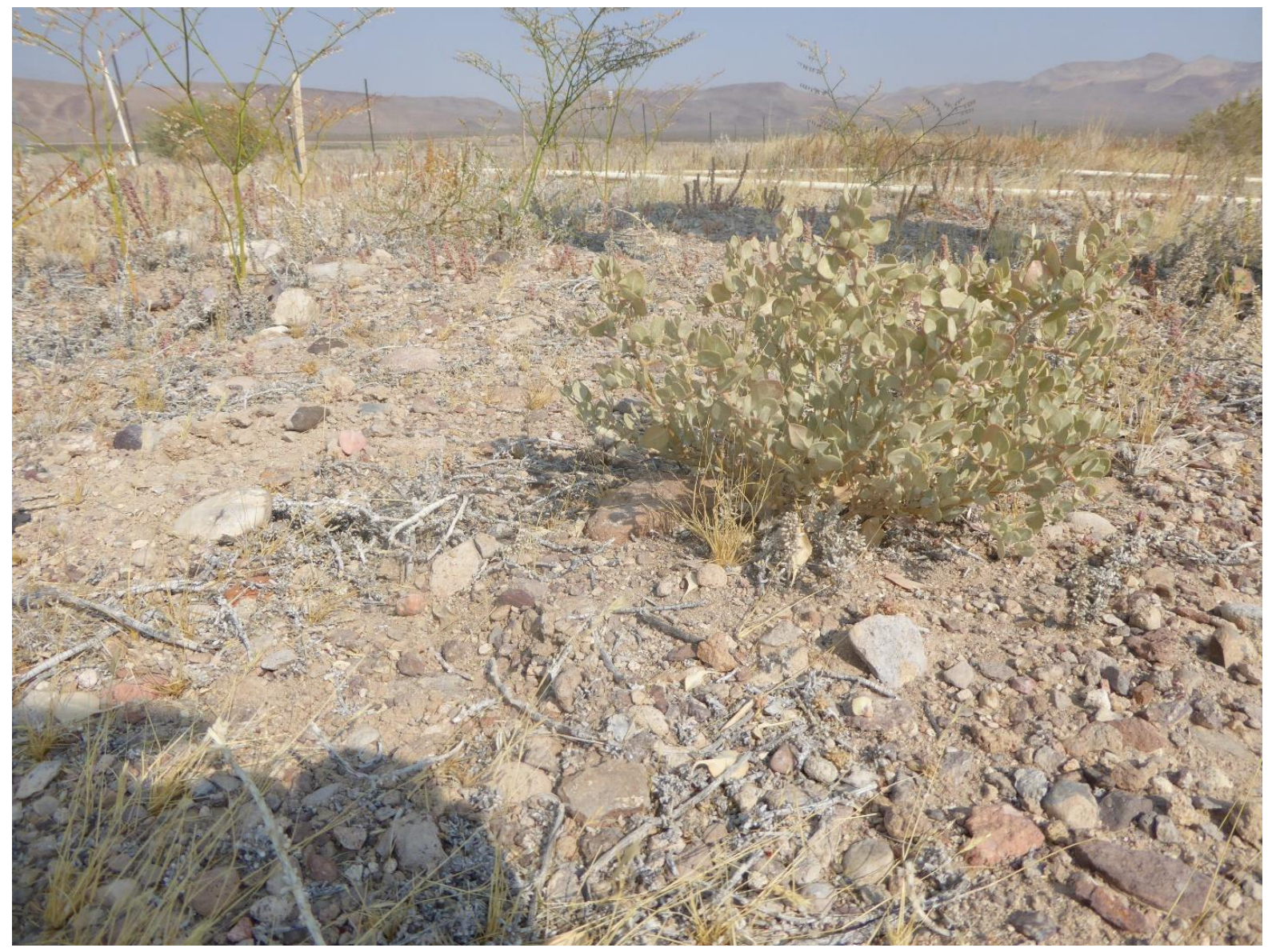

Figure A-10. A healthy shadscale established from seed in a plot with native Eriogonum sp. (skeleton weed or flat-topped buckwheat, which was not in the seed mix but still started to grow in the plots) established in the background. 


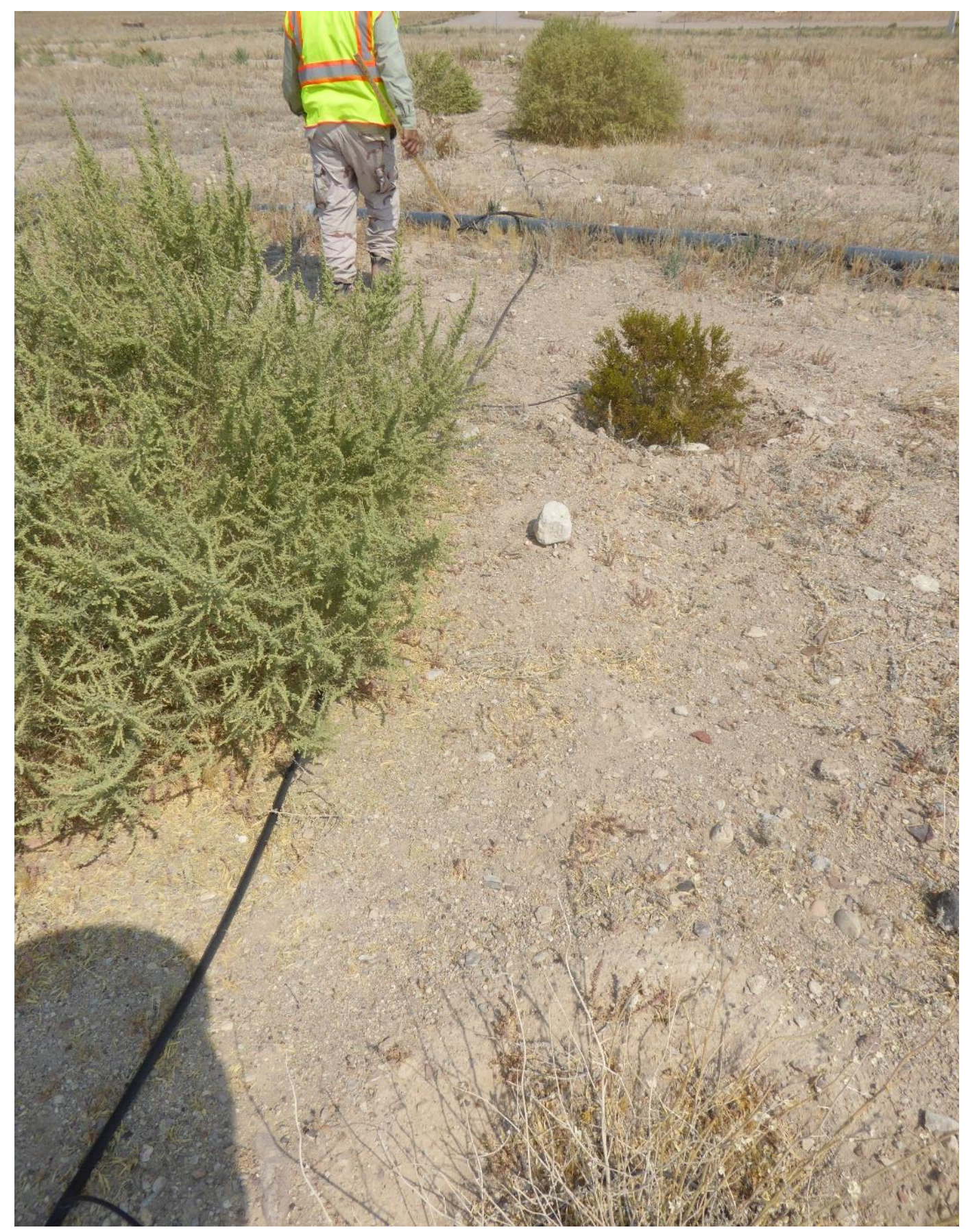

Figure A-11. Walking along one of the $10 \mathrm{~m} \times 100 \mathrm{~m}(32.8 \mathrm{ft} \times 328 \mathrm{ft})$ plots with well-established transplants. 

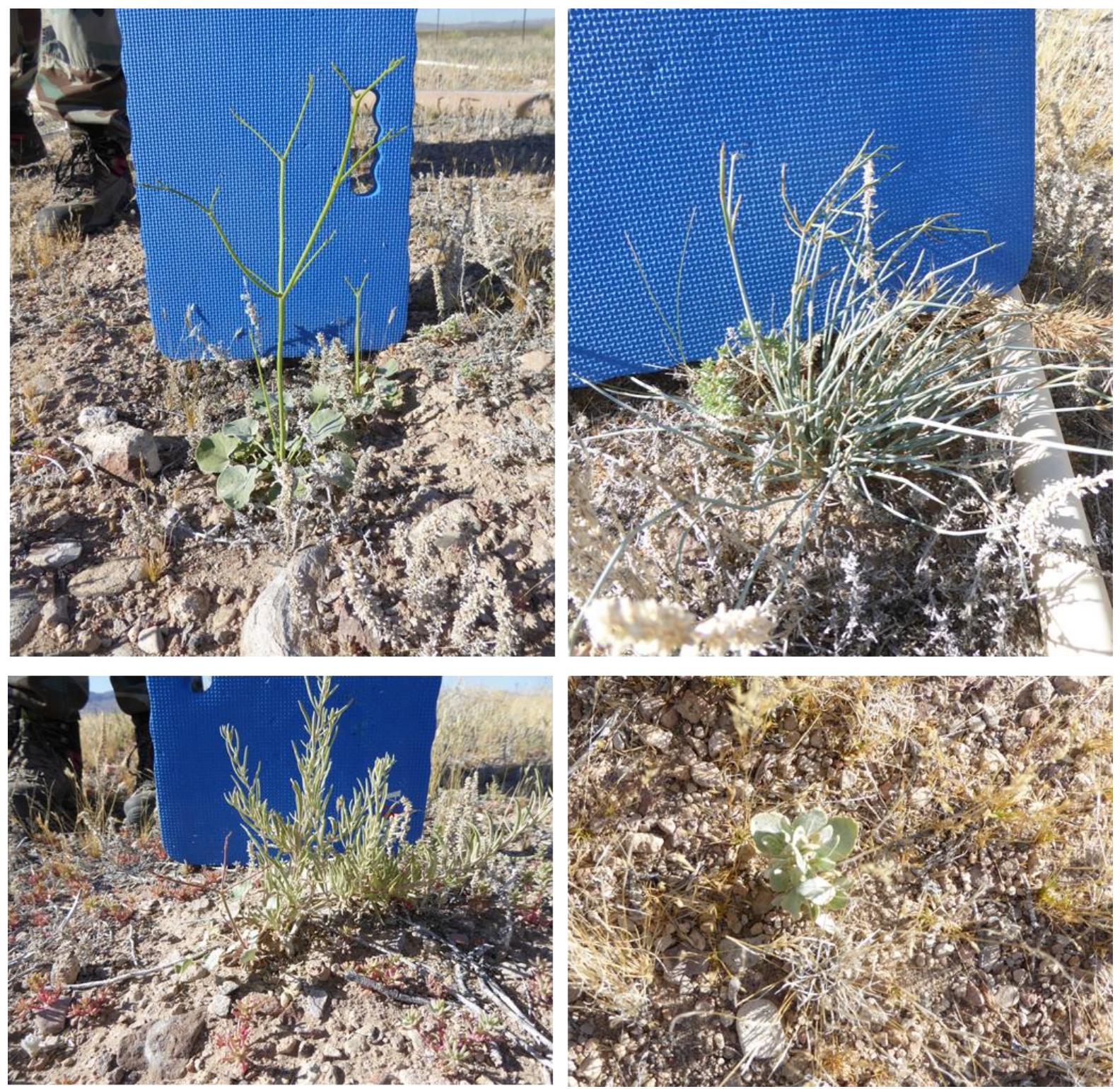

Figure A-12. Some of the many native plant seedlings observed. Shown here are skeleton weed (top left), Indian tea (top right), four-wing (bottom left), and shadscale (bottom right). 


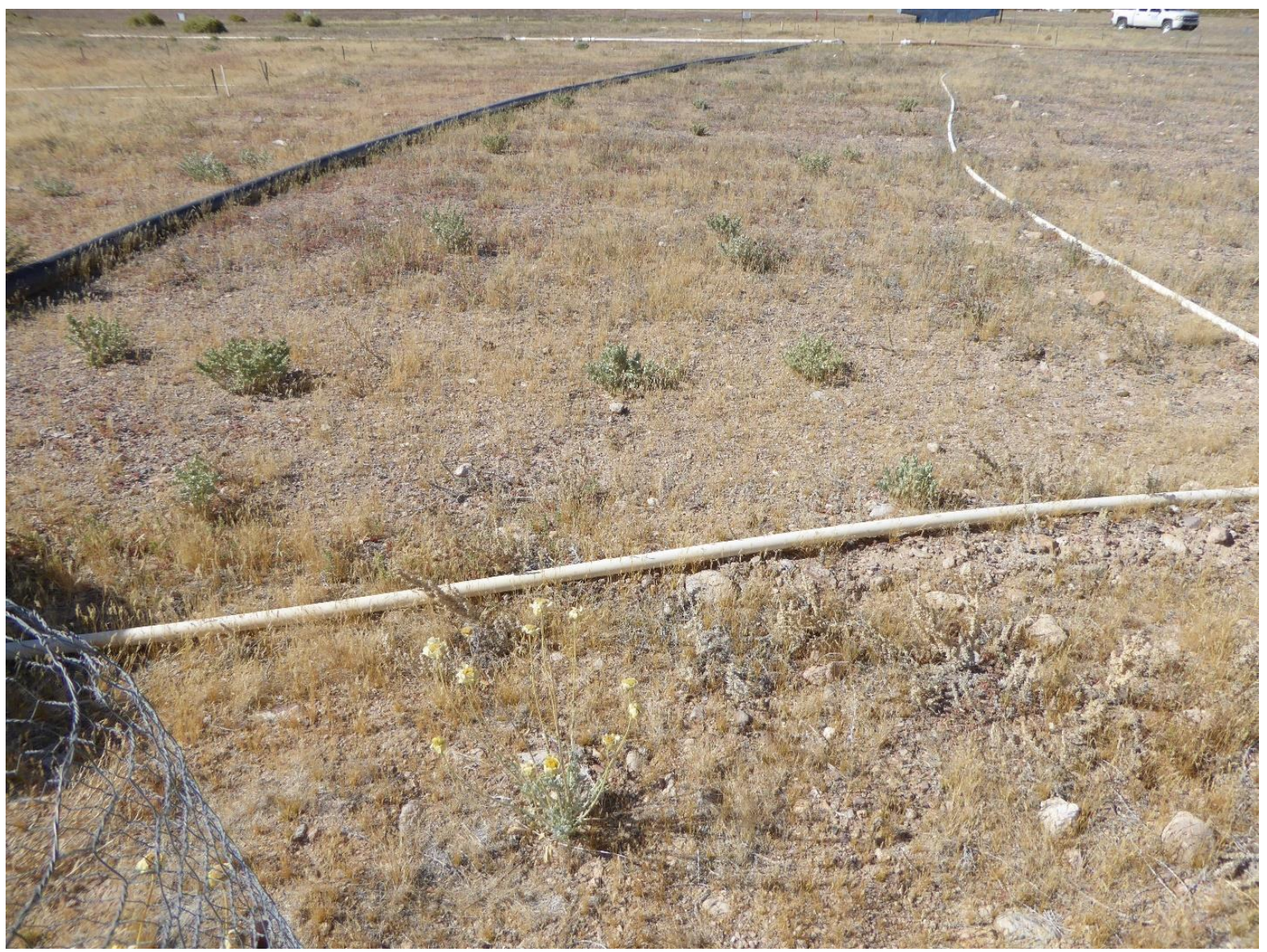

Figure A-13. Shadscale seedlings outside of the $10 \mathrm{~m} \times 10 \mathrm{~m}(32.8 \mathrm{ft} \times 32.8 \mathrm{ft})$ plots. 

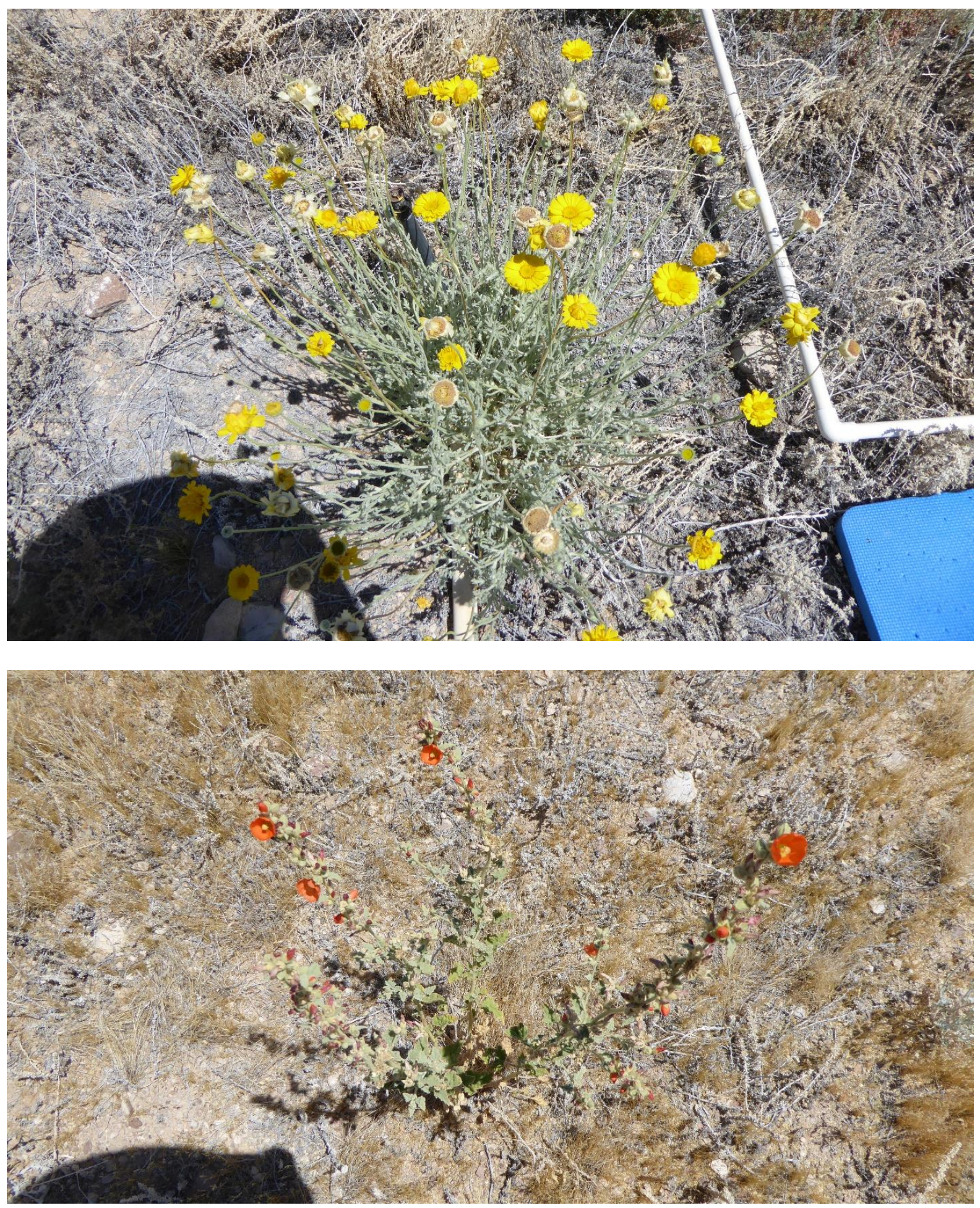

Figure A-14. Flowering marigold (top) and globemallow (bottom). 


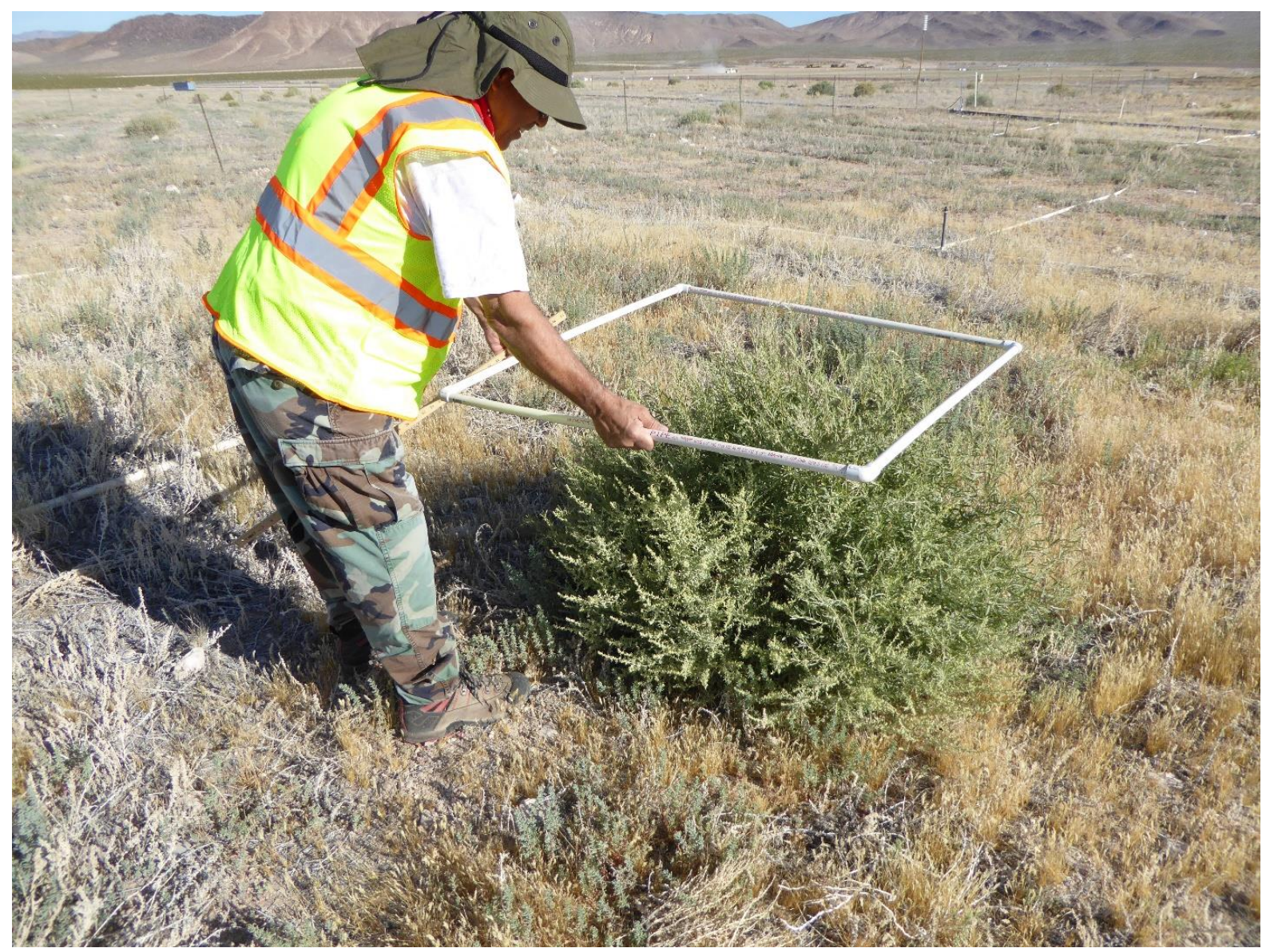

Figure A-15. A TRC member with a very healthy four-wing saltbrush. 


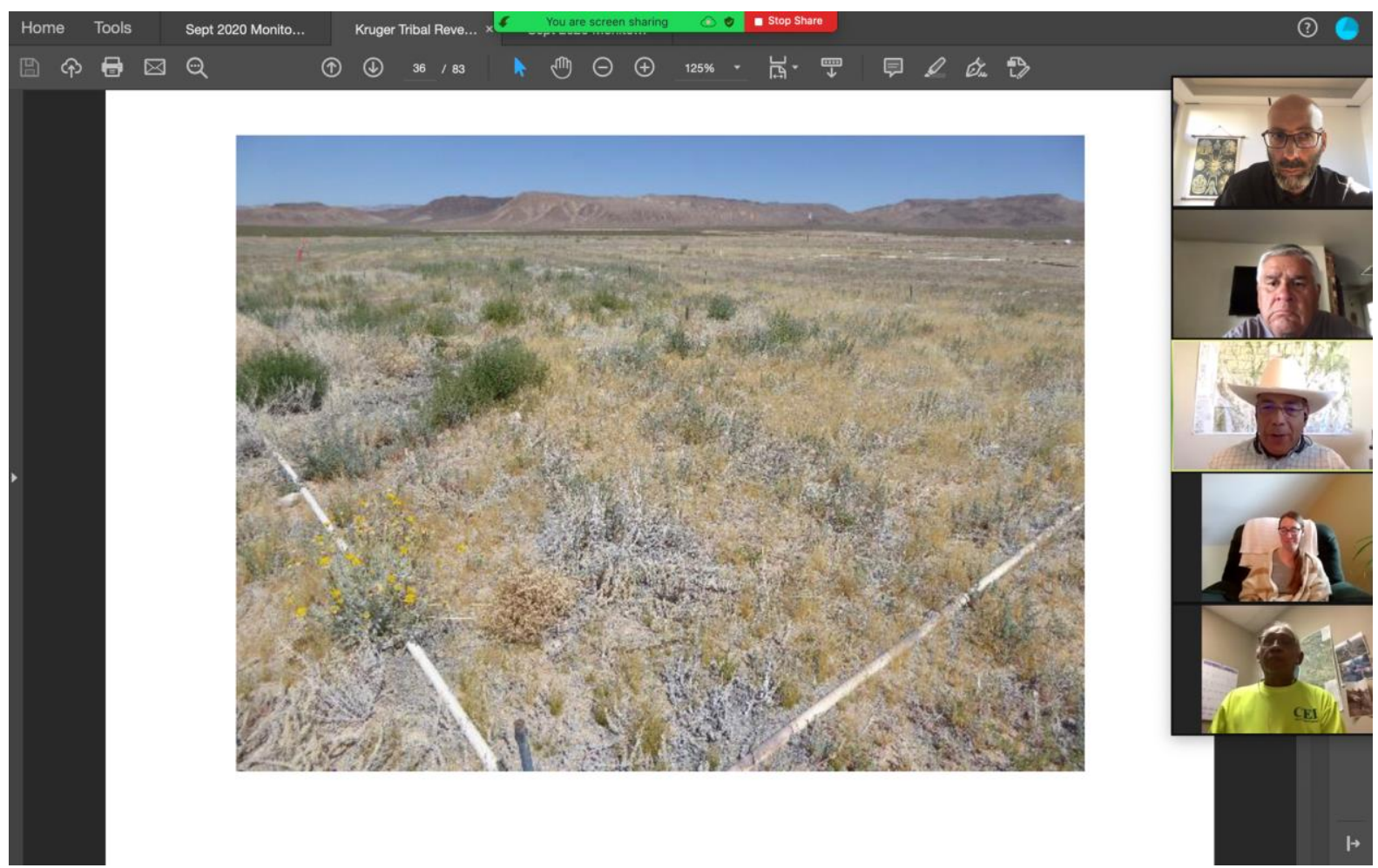

Figure A-16. Virtual TRC meeting in May 2020 to discuss the status of the revegetation plots.

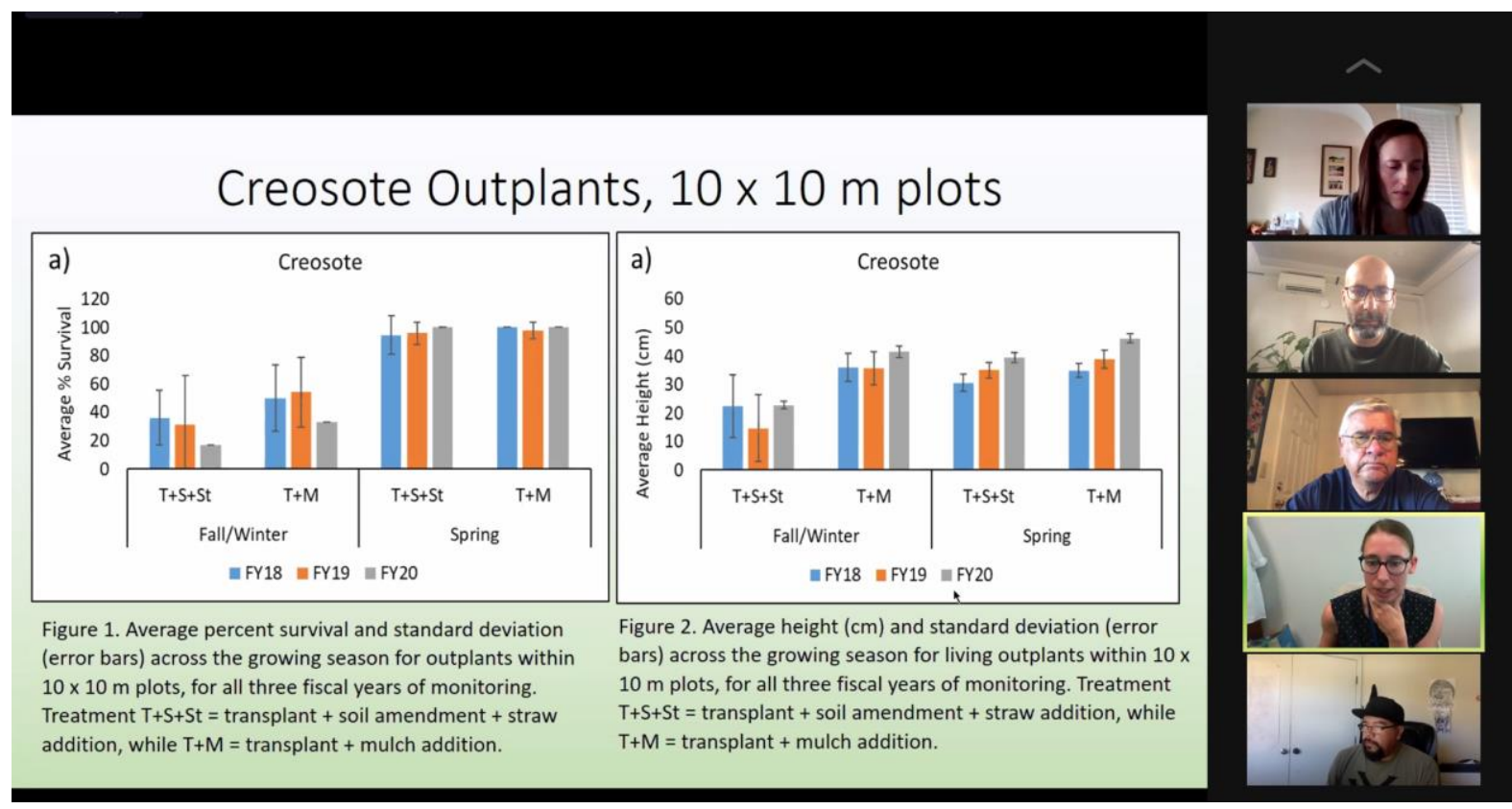

Figure A-17. Virtual TRC annual meeting in October 2020 to discuss empirical results of the revegetation study. 


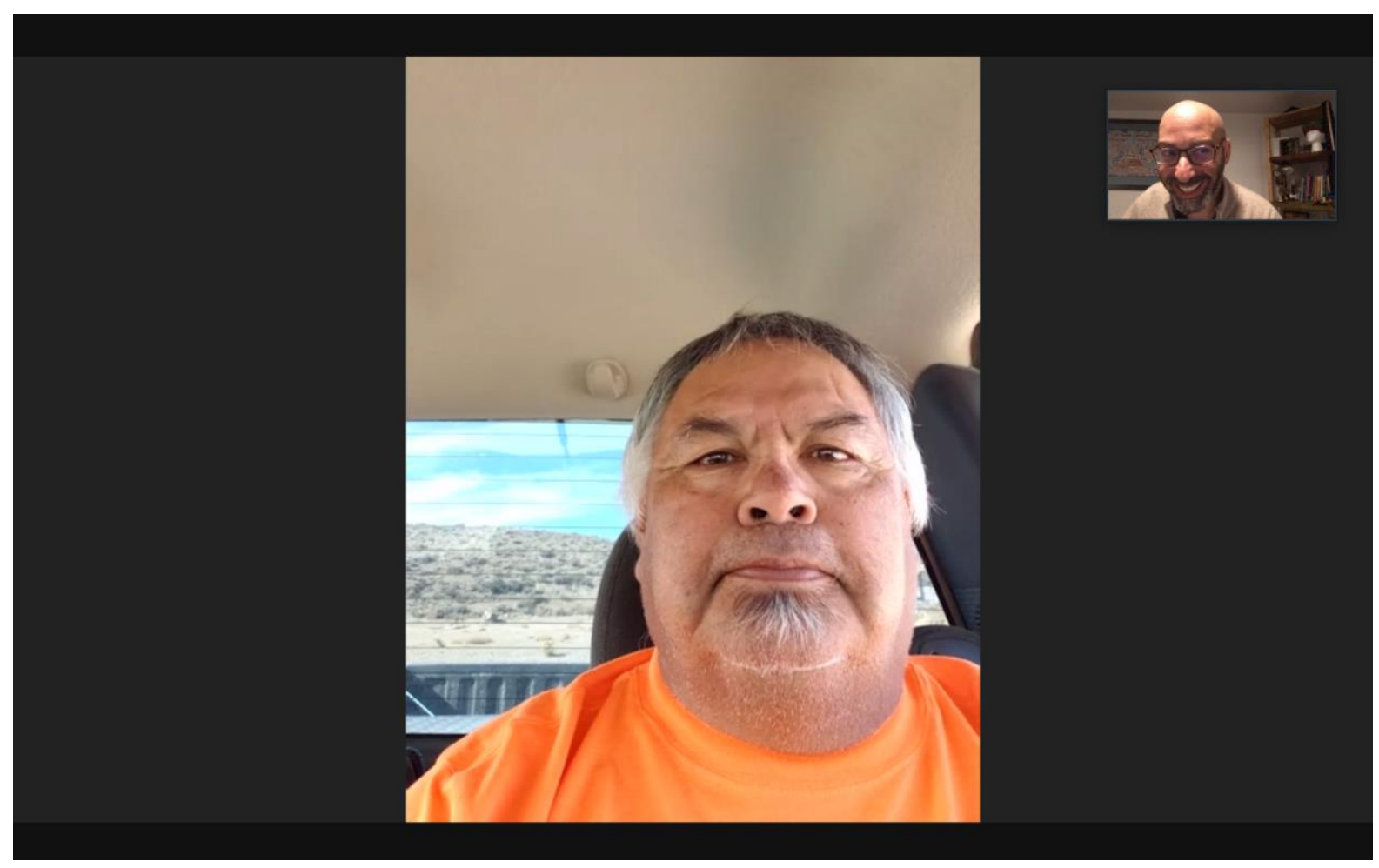

Figure A-18. Virtual in-depth interview with TRC member, November 2020.

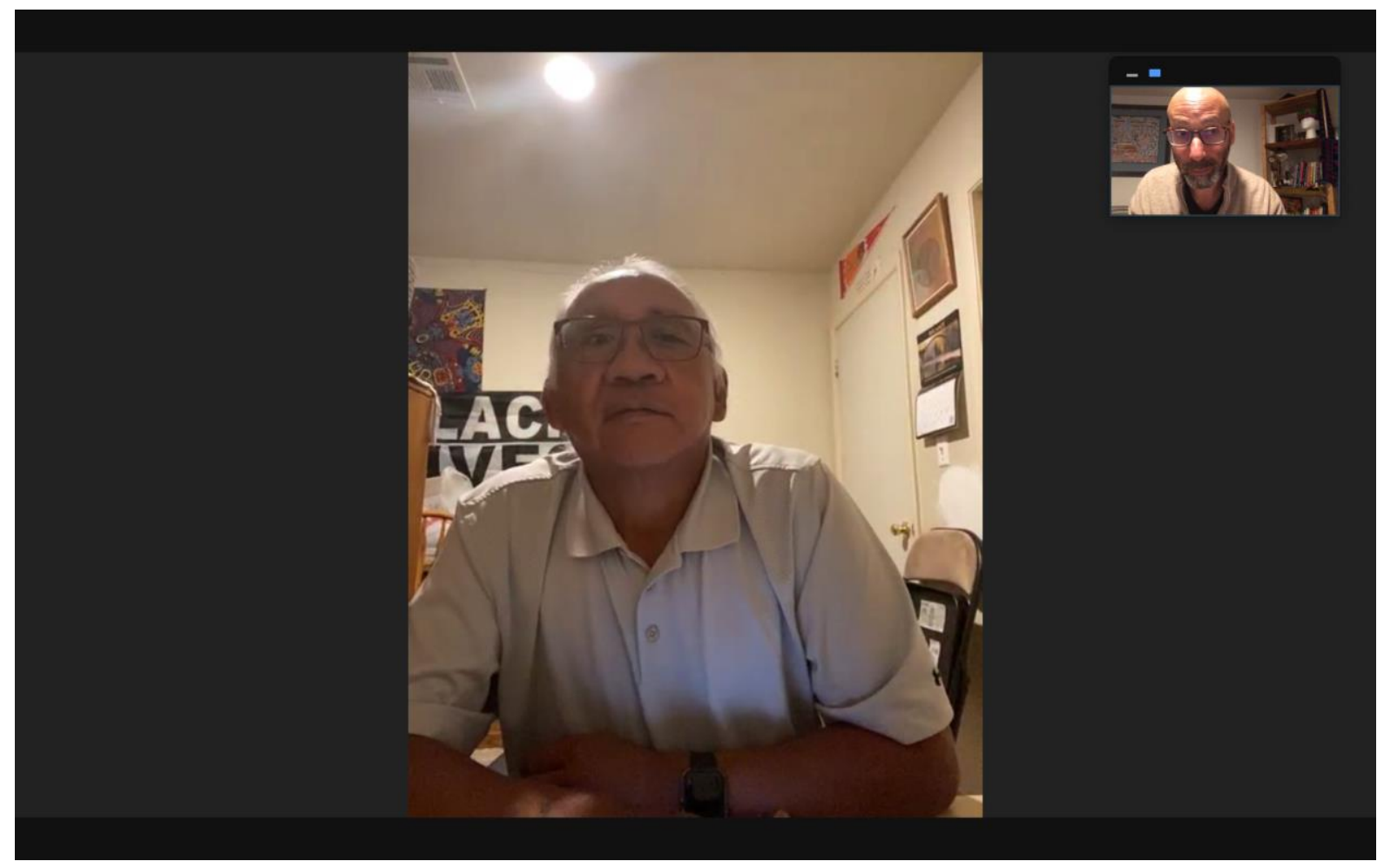

Figure A-19. Virtual in-depth interview with TRC member, November 2020. 


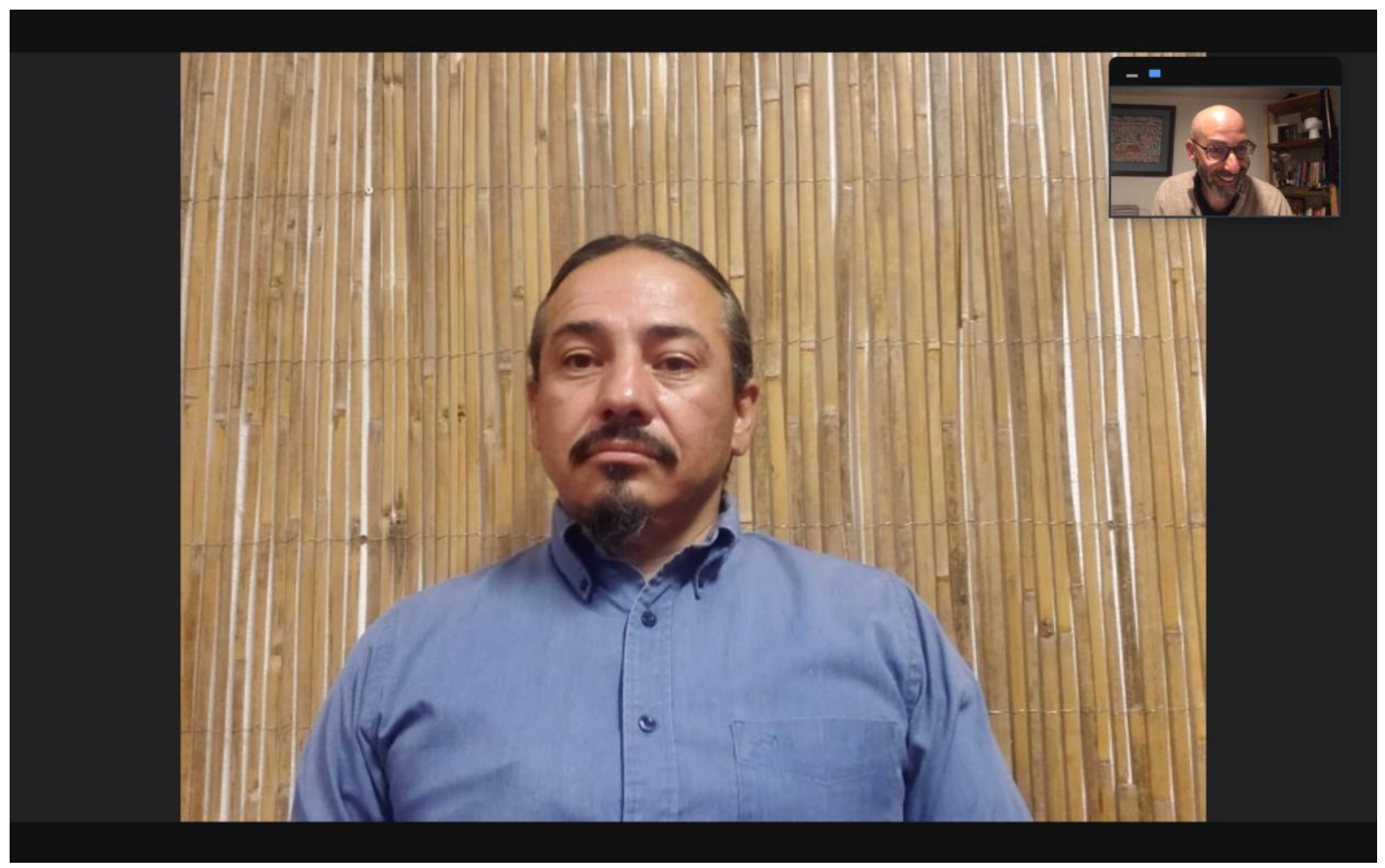

Figure A-20. Virtual in-depth interview with TRC member, November 2020.

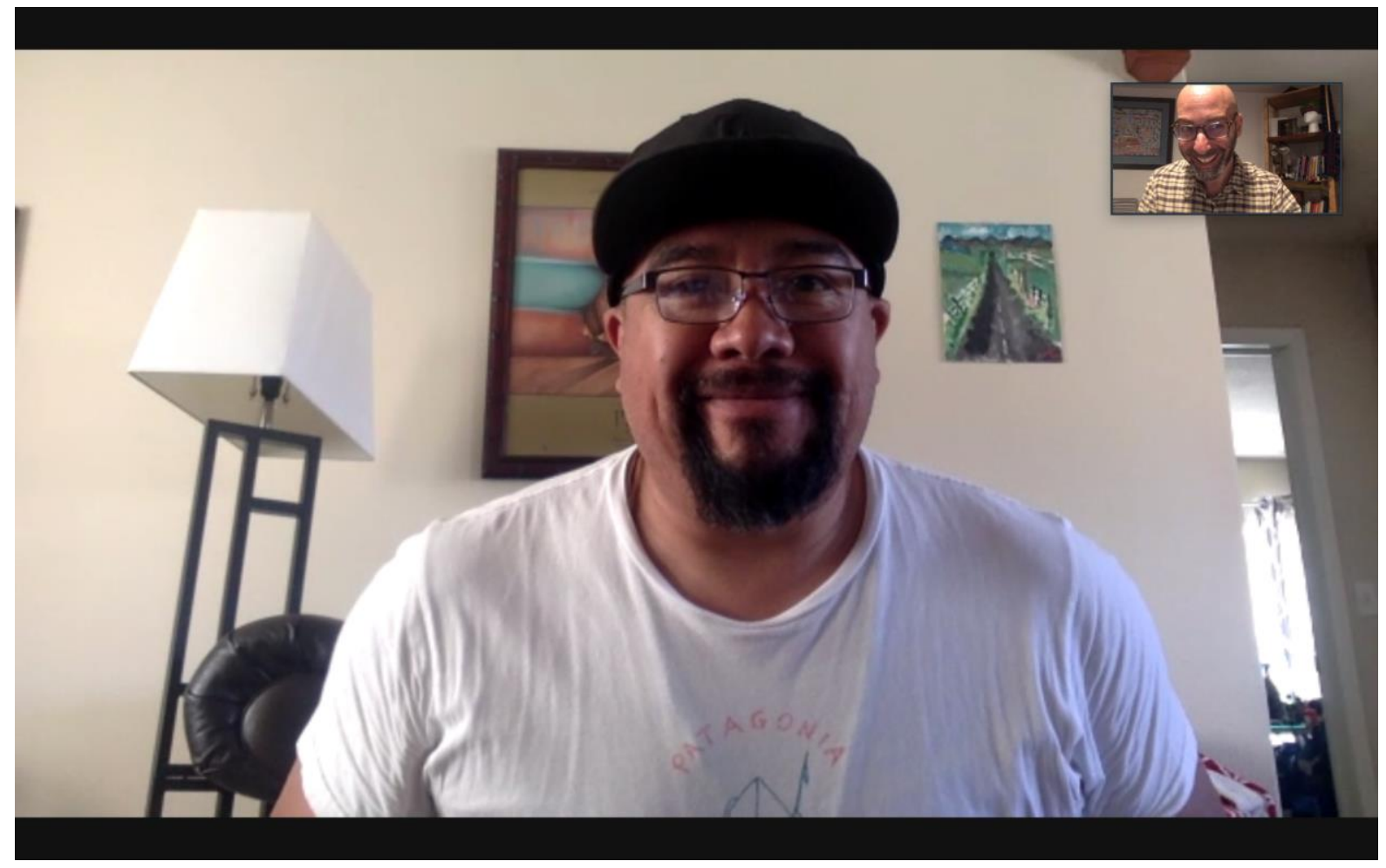

Figure A-21. Virtual in-depth interview with TRC member, November 2020. 


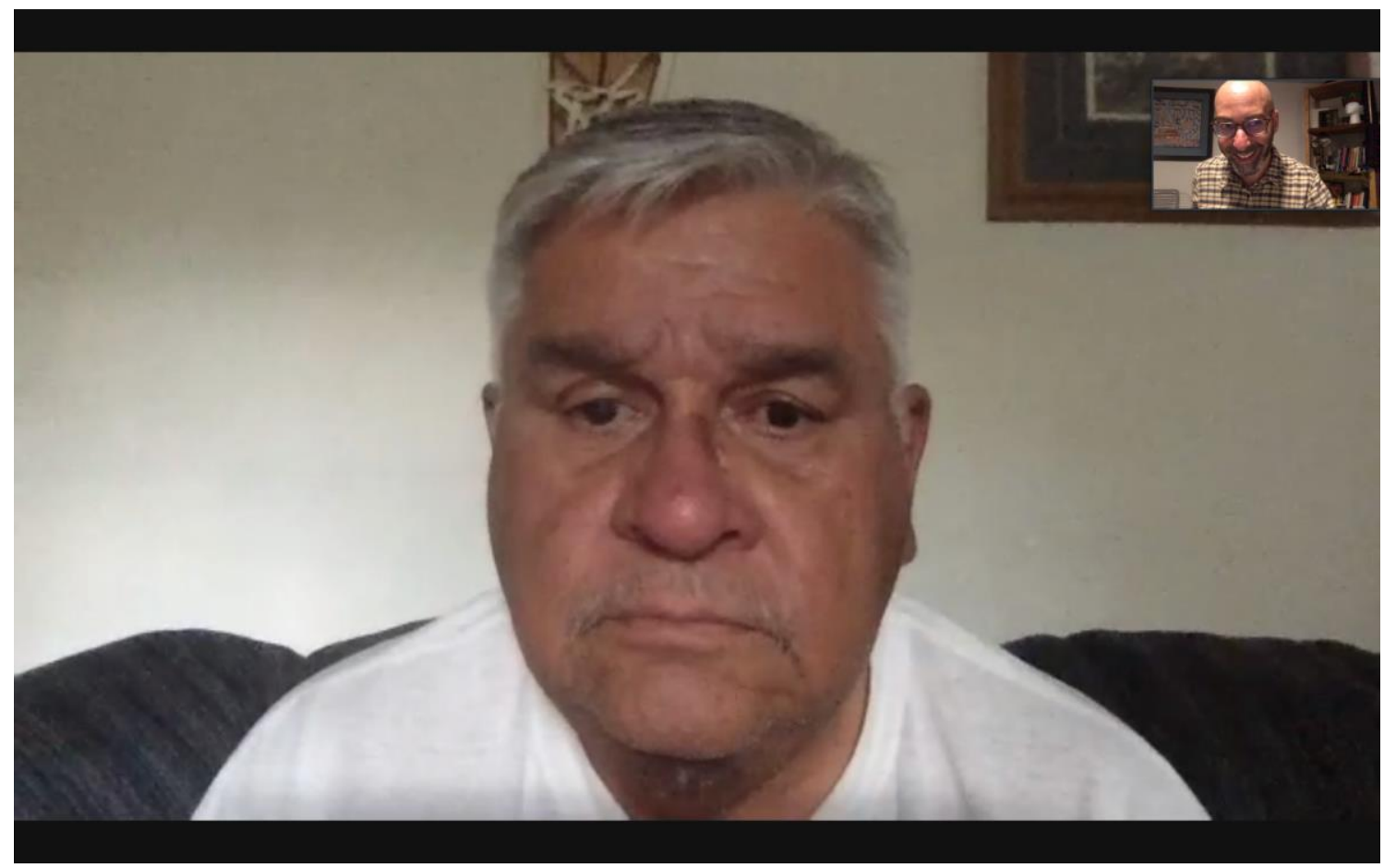

Figure A-22. Virtual in-depth interview with TRC member, November 2020.

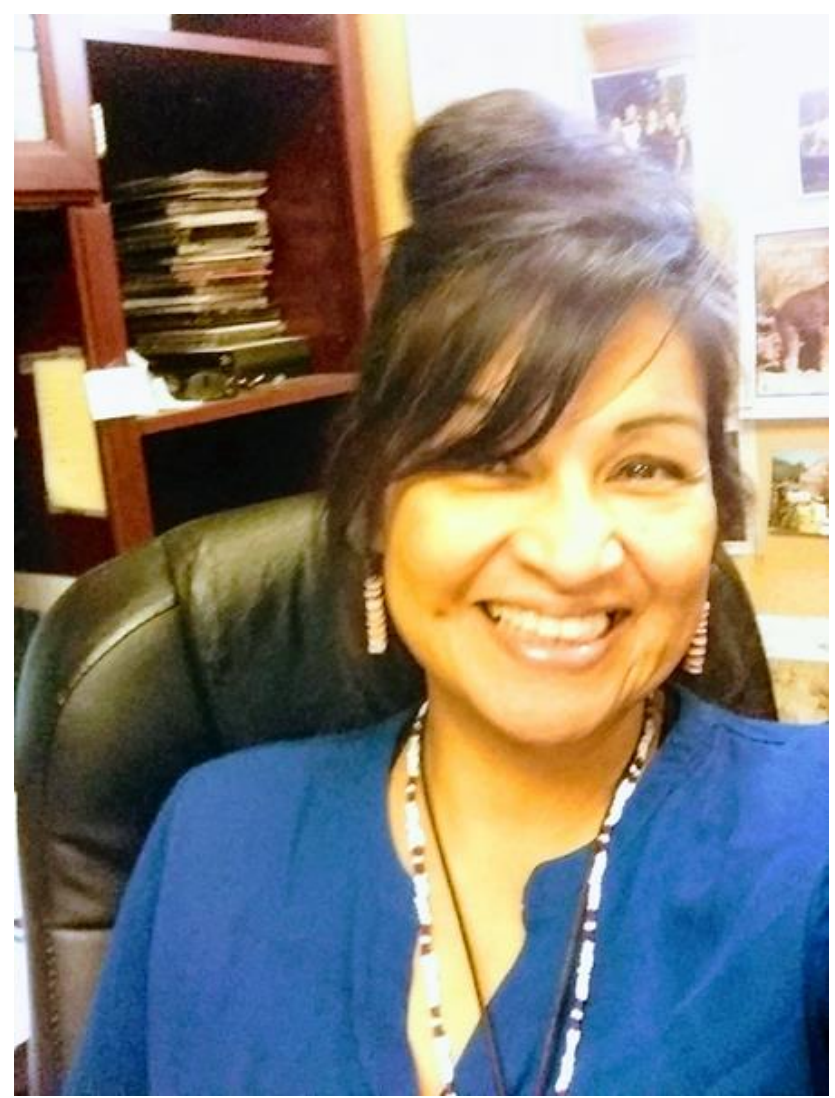

Figure A-23. Virtual in-depth interview with TRC member, November 2020. 


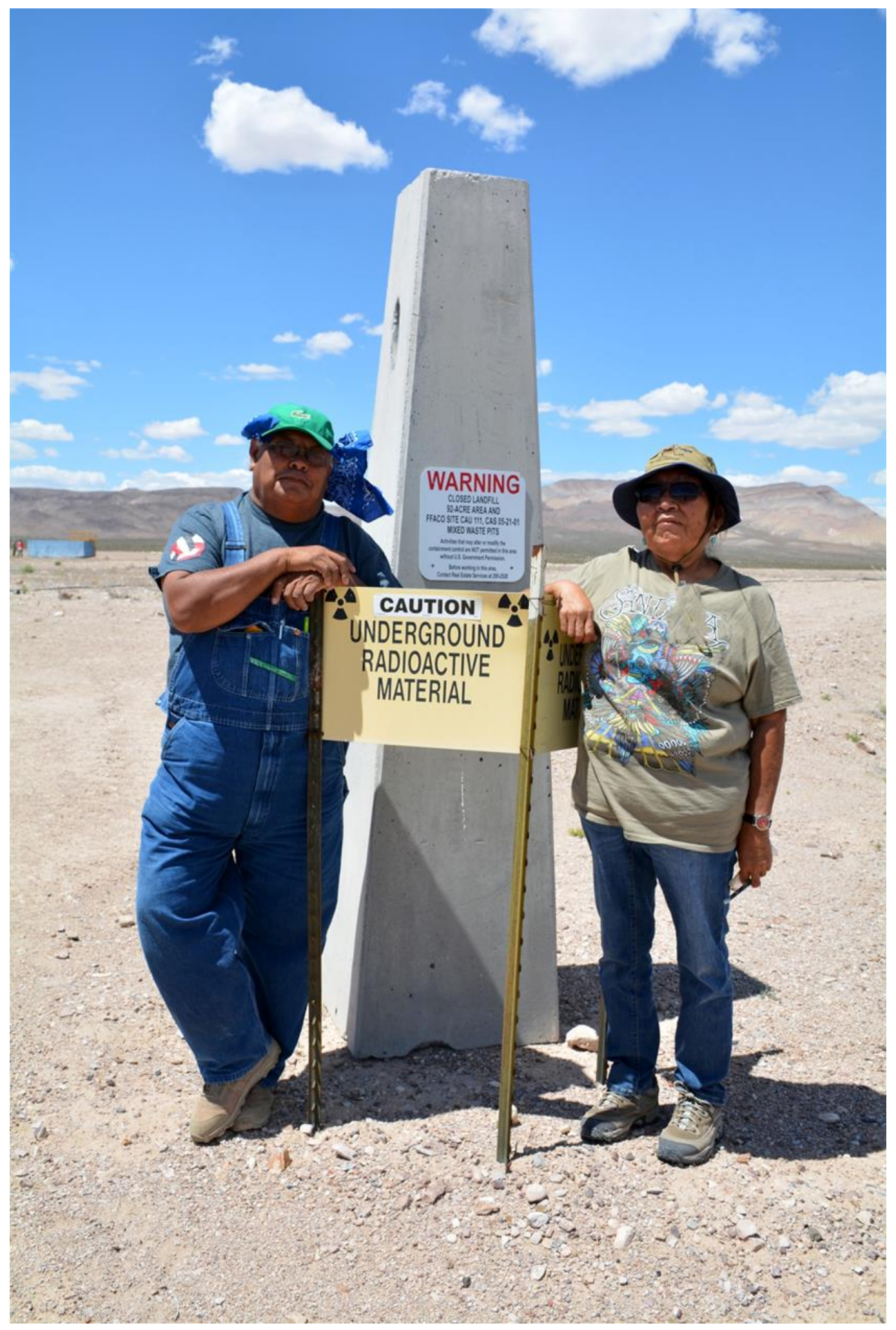

Figure A-24. Virtual in-depth interview participant (right) with other TRC member, March 2016. 


\section{STANDING DISTRIBUTION LIST}

Robert Boehlecke

EM NV Program Manager

Department of Energy

Environmental Management Nevada Program

100 N. City Parkway, Suite \#1750

Las Vegas, NV 89106

Robert.Boehlecke@emcbc.doe.gov

Bill Wilborn

EM NV Deputy Program Manager, Operations

Department of Energy

Environmental Management Nevada Program

100 N. City Parkway, Suite \#1750

Las Vegas, NV 89106

Bill.Wilborn@emcbc.doe.gov

Tiffany Gamero

Long-Term Monitoring Activity Lead

Department of Energy

Environmental Management Nevada Program

100 N. City Parkway, Suite \#1750

Las Vegas, NV 89106

Tiffany.Gamero@emcbc.doe.gov

Jeff Berger

Nevada Field Office

National Nuclear Security Administration

U.S. Department of Energy

P.O. Box 98518

Las Vegas, NV 89193-8518

Jeff.Berger@nnsa.doe.gov
Patrick Sawyer

DOE Program Manager

Division of Hydrologic Sciences

Desert Research Institute

755 E. Flamingo Road

Las Vegas, NV 89119-7363

Patrick.Sawyer@dri.edu

Julianne Miller

DOE Soils Activity Manager

Division of Hydrologic Sciences

Desert Research Institute

755 E. Flamingo Road

Las Vegas, NV 89119-7363

Julie.Miller@dri.edu

Pat Matthews

Navarro, LLC

Department of Energy

Environmental Management Nevada Program

100 N. City Parkway, Suite \#1750

Las Vegas, NV 89106

Patrick.Matthews@emnv.doe.gov

Alissa Silva

Mission Support and Test Services (MSTS)

P.O. Box 98521

M/S NLV082

Las Vegas, NV 89193-8521

silvasaj@nv.doe.gov

All on distribution list receive one electronic PDF copy, unless otherwise noted. 